\title{
The co-management of the Te Arawa Lakes
}

\author{
Julia Kahu Harper-Hinton
}

A dissertation submitted in partial fulfilment of the requirements of the degree of

$$
\text { Master of Laws }
$$

Victoria University of Wellington

2015 


\section{Table of Contents}

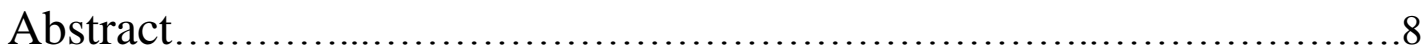

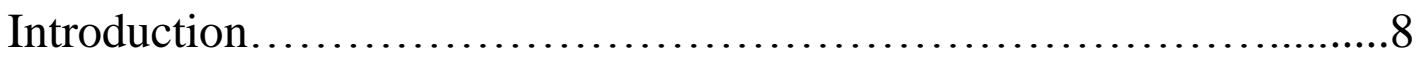

A Research Focus.................................................................11

Chapter One: Co- management History and Theories..................13

I Introduction.................................................................

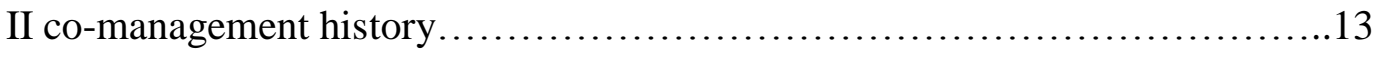

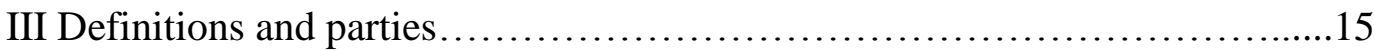

IV Types of co-management............................................... 20

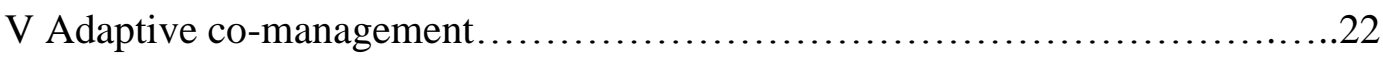

VI Studying a co-management example.....................................24

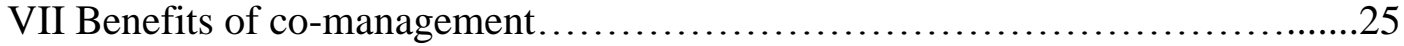

A Utilising strengths of all stakeholders............................... 25

B Co-management as an antidote to the tragedy of the commons..........27

VIII Potential drawbacks of co-management for indigenous peoples................29

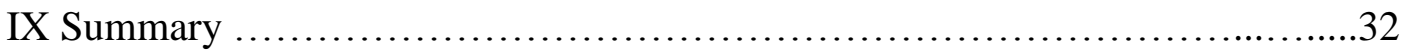

Chapter Two: History of the Te Arawa Lakes......................................33

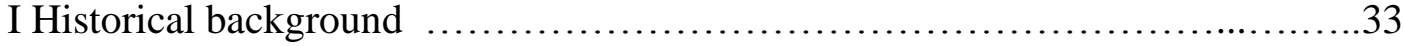

II Relationship of Te Arawa with the lakes ...................................35

III Outline of the Te Arawa Lakes .............................................40

A Lake Rotorua-nui-a-Kahumatamomoe .............................42

B Lake Rotoiti...................................................... 42

C Lake Rotoehu..................................................... 43

D Lake Rotomā........................................................

E Lake Ōkataina ................................................... 44

F Lake Tikitapu..................................................... 44

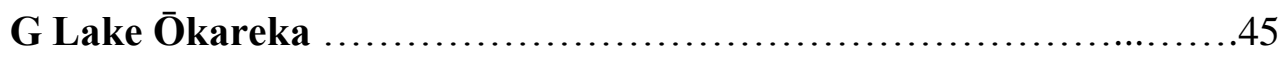

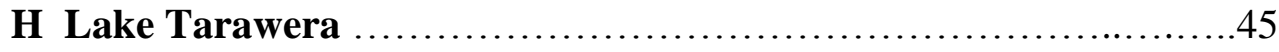


I Lake Rotomahana ................................................ 45

J Lake Rerewhakaaitu.......................................... 46

K Lake Ōkaro (also known as Ngākaro) ............................46

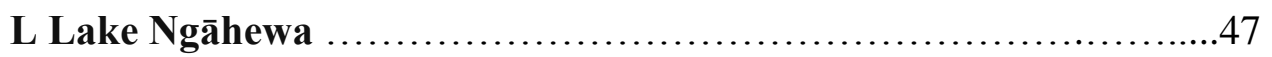

IV The environmental damage done to the Te Arawa Lakes ecology through the Crown's introduction of foreign fish species and nutrient input ...................47

A Destruction of the Kōaro .......................................4

B Impact of land clearing and pastoral farming ........................49

V Ownership of the Te Arawa Lakes.........................................50

A Early Recognition of Customary Title.............................51

B The Native Land Court and Individualisation of land................53

C The subsequent actions taken by Te Arawa for recognition of their title to

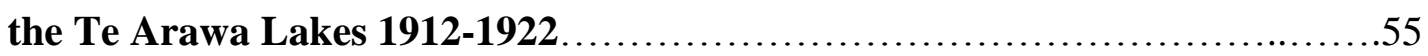

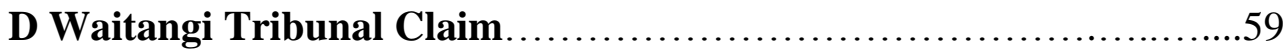

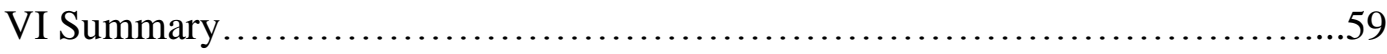

Chapter Three: Te Arawa Lakes Settlement Act 2006........................60

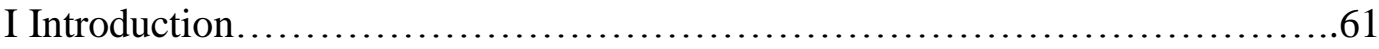

II Te Arawa Lakes Settlement Act 2006: Part 1: Acknowledgement \& Apology.61

A Acknowledgement................................................... 61

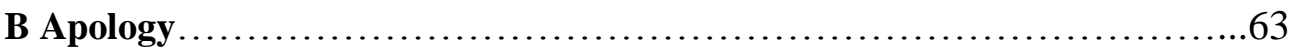

C Full and Final Settlement ..........................................63

III Te Arawa Lakes Settlement Act, 2006 Part 2: Cultural redress.................64

A Vesting of lakebeds in Te Arawa........................................64

B Limitations and encumbrances to lakebed title.........................65

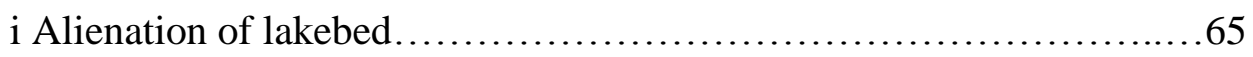

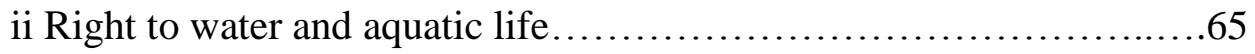

iii Liability for weeds and contamination........................... 66

iv Minerals and precious metals......................................66

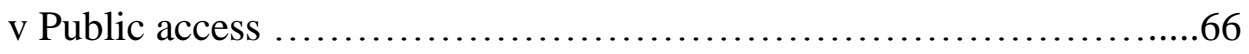

IV Te Arawa Lakes Settlement Act, 2006, Part 3: Other cultural redress - co- 
management of the Te Arawa Lakes.........................................67

A Background to the Rotorua Te Arawa Lakes Strategy Group ................67

B Rotorua Te Arawa Lakes Strategy Group................................72

C Rotorua Te Arawa Lakes Strategy Group Agreement..........................73

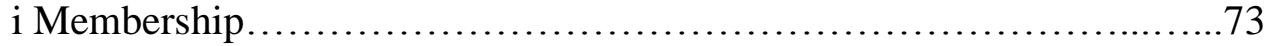

ii Quorum...................................................... 73

iii Initial functions........................................... 74

iv Amendments.................................................. 75

v About the RTALSG “organisations" .............................75

A Te Arawa Lakes Trust.............................................. 76

B Rotorua District Council........................................... 76

C Bay of Plenty Regional Council........................................... 77

D Organisations' roles and responsibilities................................ 79

i Te Arawa Lakes Trust................................................8 80

ii Rotorua District Council..............................................80

iii Bay of Plenty Regional Council....................................80

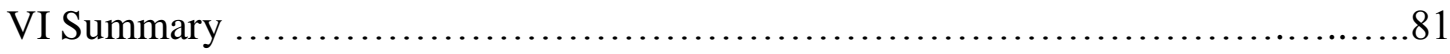

Chapter Four: The Co-management Arrangement in Practice..................83

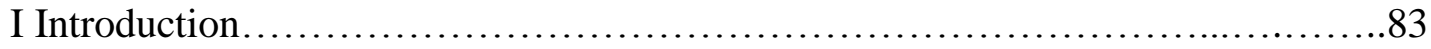

II Rotorua Te Arawa Lakes Programme....................................83

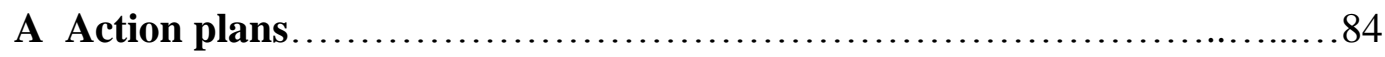

1 Focus............................................................. 86

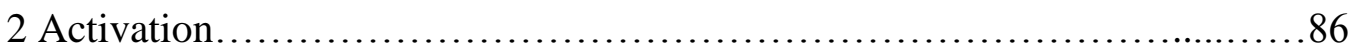

III Programme funding ................................................ 87

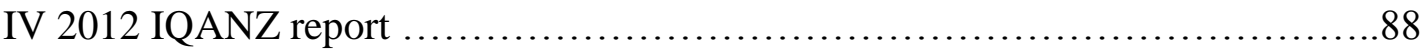

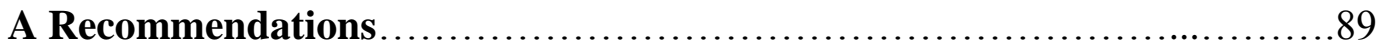

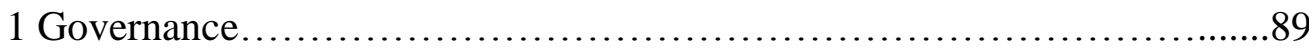

2 Management....................................................91 
B Programme Response...........................................90

V Adaption - Programme Management Plan 2013.............................91

A Rotorua Te Arawa Lakes Stratedy Group (RTALSG) ..................92

1 Decision-making ............................................ 94

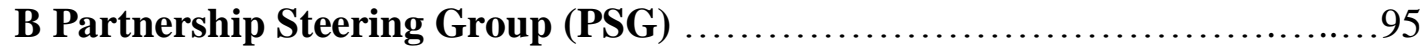

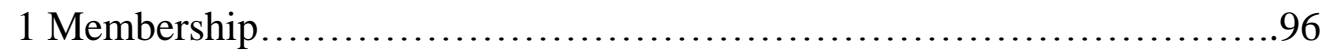

2 Role........................................................97

3 Functions ..................................................... 97

4 Limitation of Powers................................................... 98

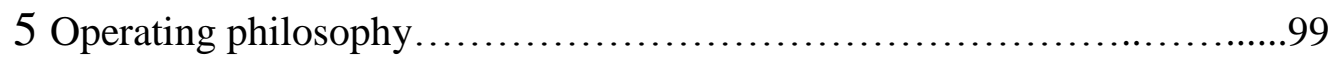

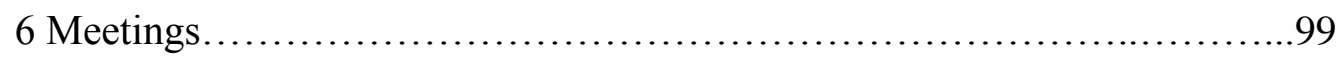

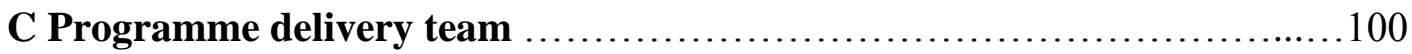

D The Programme Manager ......................................... 100

E Project co-ordinator ............................................. 101

D Workstreams ......................................................... 101

1 Stakeholder management and communications workstream...............102

2 Land operations workstream..................................... 102

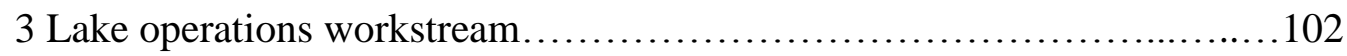

4 Project management workstream................................... 103

5 Policy and planning workstream ................................. 103

6 Sewage reticulation workstream.................................. 103

E Workstream Leaders Group ..................................... 104

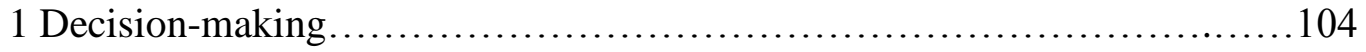

2 Meetings........................................................ 105

VI Science Management Plan .......................................... 105

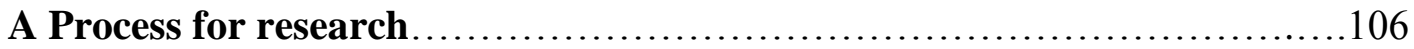

VII Advisory groups ................................................. 107

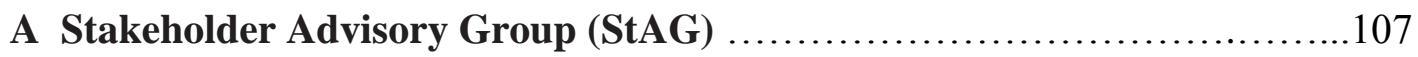

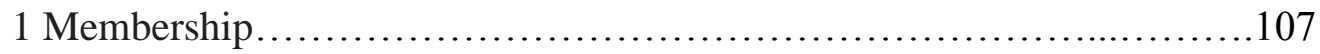

2 Role......................................................... 107 
3 Meeting and reporting....................................... 108

B Lakes Technical Advisory Group (Lakes TAG) ...................... 108

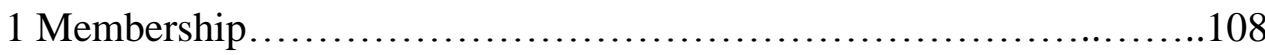

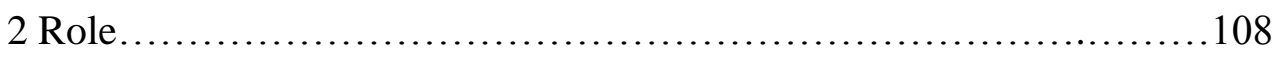

3 Meetings and reporting............................................ 109

C Land Technical Advisory Group (Land TAG) .......................110

1 Membership.......................................................110

2 Role................................................................ 110

3 Meeting and reporting...........................................110

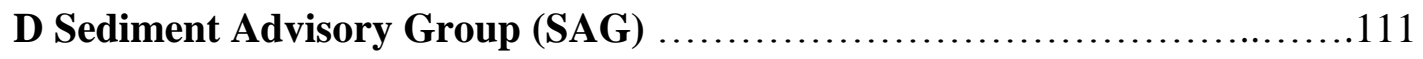

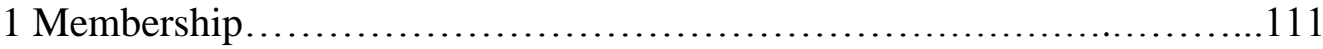

2 Role................................................................ 111

3 Meeting and reporting ............................................ 111

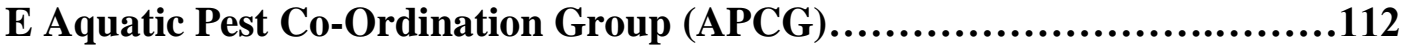

1 Membership .......................................................... 112

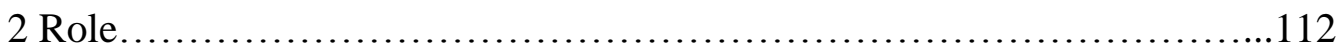

3 Meeting and Reporting..........................................112

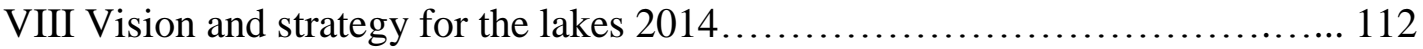

IX Adaptive co-management...........................................113

X Summary....................................................... 115

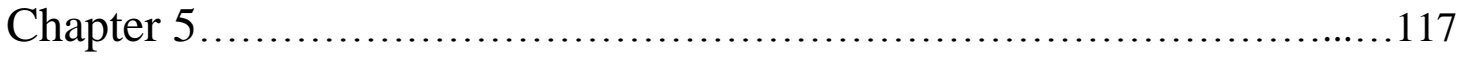

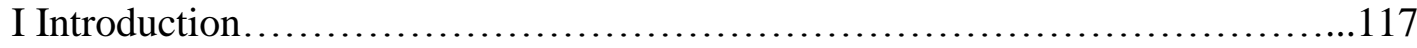

II Te Arawa involvement ............................................ 118

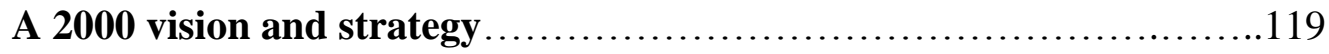

B 2014 vision and strategy ........................................

III Examples of Te Arawa initatives..........................................119

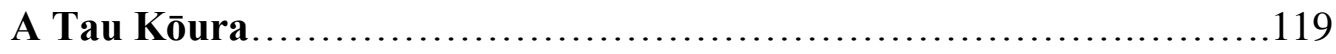

B Koaro Restoration ............................................ 120

C Cultural Health Framework....................................120

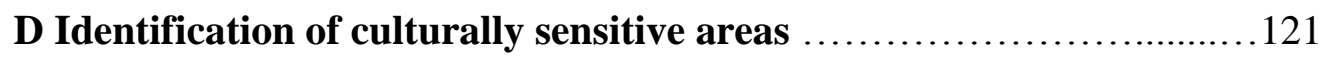


IV Summary....................................................... 121

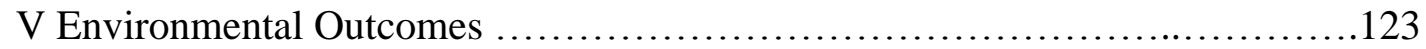

A Ohau Diversion Wall........................................... 123

i Situation....................................................123

ii Action.........................................................

iii Result....................................................124

B Cyanobacterial blooms - alum dosing ............................ 124

i Situation........................................................ 124

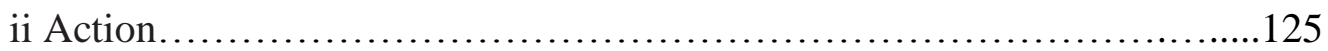

iii Result.................................................... 125

C Hamuranga Sewage Scheme.................................... 125

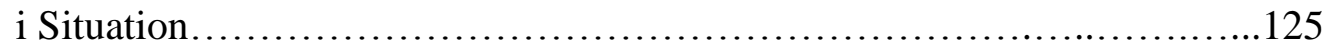

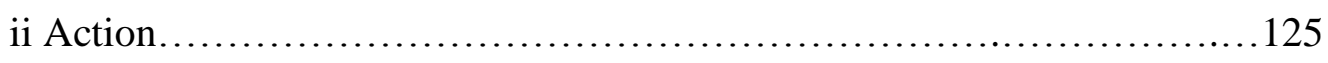

iii Result........................................................ 125

VI Actions examples of success for 2012 and 2013

V Summary............................................................. 126

Conclusion........................................................ 128 


\section{Abstract}

The restoration of indigenous rights to and interests in their traditional natural resources needs to be accompanied by practical ways in which indigenous values in relation to a resource can be met. Co-management or co-governance has emerged as an option for indigenous people in settling historical land and resource claims. Co-management offers a way in which governments and non-government entities such as and community or indigenous peoples can share decision-making over natural resources. However there are many different types and levels of co-management with, varying levels of participation and decision-making authority. Some are more effective than others at recognising indigenous values, authority and relationships. This dissertation discusses the New Zealand example of the co-management of the Te Arawa Lakes and provides an initial assessment of its cultural and environmental goals.

\section{Introduction}

This dissertation examines the co-management arrangement between the Bay of Plenty Regional Council, the Rotorua District Council and the Te Arawa Lakes Trust. These three entities are responsible for the management of the Te Arawa Lakes. The management and ownership of natural resources such as the freshwater Te Arawa lakes is a contentious issue. In New Zealand, water ownership is not defined in law but its use, access and withdrawal are. ${ }^{1}$ Natural resources have been defined as "materials or substances occurring in nature which can be exploited for economic gain."2 Everything which we use in our daily life contains either natural resources (for example wooden furniture) or is created using natural resources (for example food requiring water to

\footnotetext{
${ }^{1}$ See: Jacinta, Ruru (2009). "Undefined and unresolved: Exploring indigenous rights in Aotearoa New Zealand's freshwater legal regime." Journal of Water Law, 20(5/6), 236-242.; Guy Salmon, Matilda Sundström and Kim Zilliacus "Environmental Management and Natural Resource Allocation Frameworks of New Zealand, Sweden and Finland: A Comparative Description Ecologic Foundation" (2005) New Zealand Ecologic Research Report No 1, at 13.

2 "Natural Resources" Oxford Dictionaries Available:http://oxforddictionaries.com/definition/english/natural-resources Accessed: 21/02/2015
} 
grow). ${ }^{3}$ Natural Resources are "a major source of national income, and are also a major cause of conflict and instability if mismanaged or shared unfairly." "The sustainable management of natural resources is critical. Co-management has emerged as one option for managing the earth's natural resources and presents a way to facilitate cooperation amongst resource users and government, particularly where there are competing property rights.

Indigenous people throughout the world have had their rights to property and resources overtaken through colonisation. The indigenous people of New Zealand are the Māori, ${ }^{5}$ and New Zealand was colonised by the British Empire. The Treaty of Waitangi signed in 1840 between Māori and the Crown guaranteed that Māori would retain control over their resources and taonga. ${ }^{6}$ But this guarantee was not honored. In the ensuing years Māori were excluded from the management of the natural resources they traditionally owned and managed pre-colonisation as Crown legislation and policies enabled them to take control of governance of lakes, fisheries, native forests and other natural resources.

In 1992, the Rio Declaration On Environment and Development ${ }^{7}$ acknowledged that indigenous peoples were vital to environmental management and development and urged states to support indigenous ${ }^{8}$ participation in the achievement of sustainable ${ }^{9}$ development: ${ }^{10}$

\footnotetext{
${ }^{3}$ World Trade Report 2010 at 46

Available: http://www.wto.org/english/res_e/booksp_e/anrep_e/wtr10-2b_e.pdf

Accessed: 21/03/2015

Therefore everything on earth could potentially be considered a natural resource even those manmade items which utilize natural resources in their production.

${ }^{4}$ Nicholas Haysom and Sean Kane Briefing Paper Centre for Humanitarian Dialogue Negotiating Natural Resources for Peace: Ownership, control and wealth-sharing, (Henry Dunant Centre for Humanitarian Dialogue, 2009), at 5.

Available: http://comparativeconstitutionsproject.org/files/resources_peace.pdf

Accessed : 22/02/2015

${ }^{5}$ Michael King, The Penguin History of New Zealand (Penguin Books NZ Limited, Auckland, 2003 ), at 8.

${ }^{6}$ The Treaty of Waitangi 1840, art 2

${ }^{7}$ Rio Declaration on Environment and Development A/CONF.151/26 (Vol. I) 14 June 1992, Rio de Janeiro, Brazil

${ }^{8}$ Convention 169 defines Indigenous Peoples as: a) tribal peoples in independent countries whose social, cultural and economic conditions distinguish them from other sections of the national community and whose status is regulated wholly or partially by their own customs or traditions or by special laws or regulations;
} 
Principle 22

Indigenous people and their communities and other local communities have a vital role in environmental management and development because of their knowledge and traditional practices. States should recognize and duly support their identity, culture and interests and enable their effective participation in the achievement of sustainable development.

The state's role as the sole holder of rights to natural resources is now changing with the recognition that governments alone cannot manage complex resources. ${ }^{11}$ Increased acknowledgement of indigenous people's rights to land and resources has resulted in the emergence of co-management as an option for recognising indigenous rights. Comanagement has become a vehicle through which indigenous peoples can re-engage with the management of natural resources, potentially regaining some of the management functions that they have been stripped of. Collaboration between the state and the indigenous people can be arranged to provide for varying degrees of influence and genuine participation to realise effective co-management.

b) peoples in independent countries who are regarded as indigenous on account of their descent from the populations which inhabited the country, or a geographical region to which the country belongs, at the time of conquest or colonization or the establishment of present state boundaries and who irrespective of their legal status, retain some or all of their own social, economic, cultural and political institutions2. Selfidentification as indigenous or tribal shall be regarded as a fundamental criterion for determining the groups to which the provisions of this Convention apply (Article 1). By the working group on indigenous issues Indigenous communities, peoples and nations are those which, having a historical continuity with preinvasion and pre-colonial societies that developed on their territories, consider themselves distinct from other sectors of the societies now prevailing in those territories, or parts of them. They form at present nondominant sectors of society and are determined to preserve, develop, and transmit to future generations their ancestral territories, and their ethnic identity, as the basis of their continued existence as peoples, in accordance with their own cultural patterns, social institutions and legal systems. C169 - Indigenous and Tribal Peoples Convention, 1989 (No. 169)Convention concerning Indigenous and Tribal Peoples in Independent Countries (Entry into force: 05 Sep 1991)Adoption: Geneva, 76th ILC session (27 Jun 1989)

9 "Sustainable" has been defined as resource use "without compromising the ability of future generations to meet their own needs" (World Commission on Environment and Development, 1987, at 8); and The standard efficiency criterion for a resource management system is one in which the maximum level of harvest is consistent with a similar use in the future: Sara G. Singleton Constructing Cooperation: The Evolution of Institutions of Co-management, (Michigan University Press, Michigan, 1998), at 15

${ }^{10}$ Rio Declaration on Environment and Development, above n 7, principle 22

${ }^{11}$ Fikret Berkes, Lars Carlsson, "Co-management Concepts and Methological Implications" (2005) Journal of Environmental Management 75, at 65 


\section{A Research Focus}

Examples of the incorporation of co-management in New Zealand are provided by Crown Iwi settlements under the Treaty of Waitangi. This paper looks at a specific case where co-management has been used in a treaty settlement concerning the Te Arawa Lakes. The paper is broken into 5 chapters as follows:

\section{1) Co-management - history and theories}

Chapter one provides a summary of definitions of co-management from the literature and outlines some different types of co-management identified by leading commentators, then identifies some of the potential benefits of co-management in general, and some of the potential pitfalls for indigenous people in entering into co-management arrangements.

\section{2) History of the Te Arawa Lakes}

Chapter two examines the historical background of the Te Arawa Lakes area including the relationship the Te Arawa people had with the lakes, and freshwater protocols. There is a summary of Māori and English property systems and the differences in resource allocation and resource management. Chapter two then outlines the steps that led to the environmental damage done to the Te Arawa Lakes' ecology through the Crown's introduction of foreign fish species. The subsequent actions taken by Te Arawa for recognition of their title to the Te Arawa Lakes are addressed beginning with the (then) Supreme Court in 1912.

\section{3) Settlement}

Chapter three details the settlement reached between the Crown and Te Arawa in the Te Arawa Lakes Settlement Act 2006 and Memorandum of Understanding 2007. The comanagement structure currently in place for the management of the lakes is explained, and the different entities involved and their varying roles are identified. 


\section{4) Practical Study}

Chapter four aims to provide an insight into how co-management is working under the Te Arawa Lakes settlement, focusing on the groups that have been formed to implement the lakes management and the relationships between the organisations involved. There is an assessment of the type of co-management occurring in the Te Arawa Lakes, particularly whether it is adaptive co-managment.

\section{5) Outcomes for Te Arawa and the lakes}

Finally, chapter five assesses the outcomes of the arrangement for Te Arawa and the environment, looking at the level of Te Arawa involvement and areas where traditional relationship and usages of the lakes are upheld. Some specific examples of the programme interventions that have improved the water quality of the lakes are considered. 


\section{Chapter One: Co- management History and Theories}

\section{Introduction}

This chapter covers the history of co-management, moving on to the different definitions of the term and the different actors involved in a co-management arrangement. Then different types of co-management are covered including adaptive co-management. The benefits of co-management are outlined followed by some of the potential challenges faced by indigenous people when entering into co-management.

\section{Co-management History}

Early management arrangements that could now be identified as forms of comanagement have occurred in different societies throughout the world. In medieval England, the guild was collectively responsible for governing common resources. ${ }^{12}$ In $15^{\text {th }}$ century Spain, the local community was made responsible for implementing a royal decree to reforest their woodlands in response to defoliation. ${ }^{13}$ This simple "top down" form of co-management was an early example of the state devolving a degree of control and placing some autonomy for resource management in the hands of the community. The state recognised that locals had site-specific knowledge that could be put to use in effecting state policy.

According to Pinkerton, the term co-management was first used in the "late 1970s by US treaty tribes to describe the relationship they aspired to have with state managers." ${ }^{14}$ In coastal west Washington during the 1960s there were clashes between tribes and state

\footnotetext{
12 Peter Kropotkin "Mutual Aid: A Factor of Evolution, Chapter 5: Mutual Aid in the Medieval City" (1902), Kropotkin, P. Mutual Aid: A Factor of Evolution, (New York University Press, 1972), at 30

${ }^{13}$ David Guillet, "Co-management of Natural Resources: The Long View from North Western Spain" (2002) Environment and History 8, No 2. at 220.

${ }^{14}$ Evelyn Pinkerton, (2003), "Toward specificity in complexity: understanding co-management from a social science perspective” In: DC Wilson, JR Nielson,, P Degnbol, (Eds.), The Fisheries Comanagement Experience. (Kluwer, Dordrecht, 2003) at 62.
} 
agencies over salmon fishing. ${ }^{15}$ Though the tribes protested and staged 'fish ins' the State of Washington refused to recognise their rights. ${ }^{16}$ The tribes appealed for assistance from the federal government who filed a suit against Washington State in 1973 in support of the treaty tribe's rights. ${ }^{17}$ The decision became known as the Boldt decision and held that the tribes were entitled to $50 \%$ of the fish harvest in their traditional fishing grounds. ${ }^{18}$ In addition, the tribes were made 'co-managers' of the salmon resources alongside the State of Washington. ${ }^{19}$ A 'crisis' of depleted fish resources then led to the emergence of comanagement agreements between government and local fisheries. ${ }^{20}$ According to Pinkerton, fishermen had lost faith in the government's ability to manage the resource and wanted real decision-making power; it was more beneficial for the two parties to work together for a common goal than continue as they were separately. ${ }^{21} \mathrm{Co}$ management is now widely used around the world in the management of a variety of natural resources such as fisheries ${ }^{22}$ forests $^{23}$ and rivers. ${ }^{24}$ Co-management is also used in a wide range of settings such as national parks ${ }^{25}$ and for different purposes including recognising indigenous rights to land and natural resources. ${ }^{26}$

\footnotetext{
${ }^{15}$ Laura Berq "Let Them Do as They Have Promised" (1995), Hastings West-Northwest Journal of Environmental Law and Policy, Vol. 3, Issue 1, at 8

${ }^{16} \mathrm{Ibid}$, at 10

${ }^{17}$ Ibid, at 14

${ }^{18}$ United States v. Washington, 384 F. Supp. 312 (W.D. Wash. 1974), [Boldt Decision] at paragraph 36, fish that was for ceremonial or personal subsistence purposes was not included in the commercial quota.

${ }^{19}$ Berq, Above n 15, at 17

${ }^{20}$ Evelyn Pinkerton, (Ed.), (1989), Co-operative Management of Local Fisheries. (University of British Columbia Press, Vancouver) at 4.

${ }^{21}$ Ibid.

${ }^{22} \mathrm{Ibid}$, at 5

23 See for example: Eva Wollenberg, David Edmunds, Louise Buck, "Using scenarios to make decisions about the future: anticipatory learning for the adaptive co-management of community forests" Center for International Forestry Research, P.O. Box 6596 JKPWB, Jakarta, Indonesia 1006

24 See for example: Waikato-Tainui Raupatu Claims (Waikato River) Settlement Act 2010

${ }^{25}$ See for example: C.J Robinson and TJ Wallington, "Boundary work: engaging knowledge systems in comanagement of feral animals on Indigenous lands". (2012) Ecology and Society 17(2): 16.

Available: http://dx.doi.org/10.5751/ES-04836-170216

Accessed: 11/11/14

${ }^{26}$ See for example: Local Government New Zealand (2007), Co-management: case studies involving local authorities and Māori

Available:

http://policyprojects.ac.nz/phillipanorman/files/2011/10/CoManagementCaseStudiesInvolvingLocalAuthori tiesAndMaoriJanuary2007.pdf

Accessed : 22/02/2015.
} 


\section{Definitions and parties}

There appears to be consensus that there is no single accepted definition of "comanagement". ${ }^{27}$ Tipa refers to co-management as a "contested concept." ${ }^{28}$ Fikret Berkes argues that as there is a continuum of many different levels of co-management it would actually be inappropriate to have one fulsome definition. "Management" itself has been defined as: "The right to regulate internal use patterns and transform the resource by making improvements. ${ }^{.29}$ So it can be viewed as a form of property right: a right that can be dispersed amongst different stakeholders to form a co-management arrangement.

Berkes offers the broad definition that: "Co-management basically involves some combination of two "pure" management alternatives: local-level and state-level systems." Similarly, Singleton has described it as "a hybrid regime combining centralised and decentralised, state and community institutions. ${ }^{30}$ According to these definitions comanagement would be arranged between the state and community instead of two states or two non-state, community level entities. Although typically the parties to co-management are a combination of state and local level actors, it could arguably involve two local level groups managing a resource or two governments managing a resource. Berkes' definition of "co-management" - a situation in which two or more social actors negotiate, define and guarantee amongst themselves a fair sharing of the management functions, entitlements and responsibilities for a given territory, area or set of natural resources" ${ }^{\prime 3}$ seems to support the potential for co-management to be between any social actors, not

\footnotetext{
${ }^{27}$ Fikret Berkes, Peter George and Richard Preston "Co-Management: The Evolution The Theory and Practice" (1991) Joint Administration of Living Resources, TASO Research Report, Second Series, No. 1 Paper Presented at the Second Annual Meeting of IASCP University of Manitoba, Winnipeg, Canada, Sept. $26-29$, at 2.

${ }^{28}$ Gail Tipa and Richard Welch "Co-management of Natural Resources: Issues of Definition From an Indigenous Community Perspective” (2006), Journal of Applied Behavioral Science 42, at 380.

${ }^{29}$ Elinor Ostrom and Edella Schlager, Property-Rights Regimes and Natural Resources: A Conceptual Analysis (1992), Land Economics, Vol. 68, No. 3 (University of Wisconsin Press), at 250.

${ }^{30}$ Sara Singleton, "Cooperation or Capture? The Paradox of Co-management and Community Participation in Natural Resource Management and Environmental Policymaking" (2000) Environmental Politics 9(2): at 2 .

${ }^{31}$ G Borrini-Feyerabend, MT Farvar, JC Nguinguiri and V. A Ndangang, Co-management of Natural Resources: Organising, Negotiating and Learning-by-Doing. (Kasparek Verlag, Heidelberg, Germany 2000) at 1 .
} 
necessarily the state and community. However Berkes uses the term as meaning the sharing of power and responsibility between the government and local resource users. ${ }^{32}$ According to Berkes, the state level is the government and local level is the community. The state tends to have characteristics that are different from the local community and there is potential to clash over these differences. In addition there are generally "multiple government agencies and multiple local interests at play, rather than a unitary state and a homogeneous "community.",33

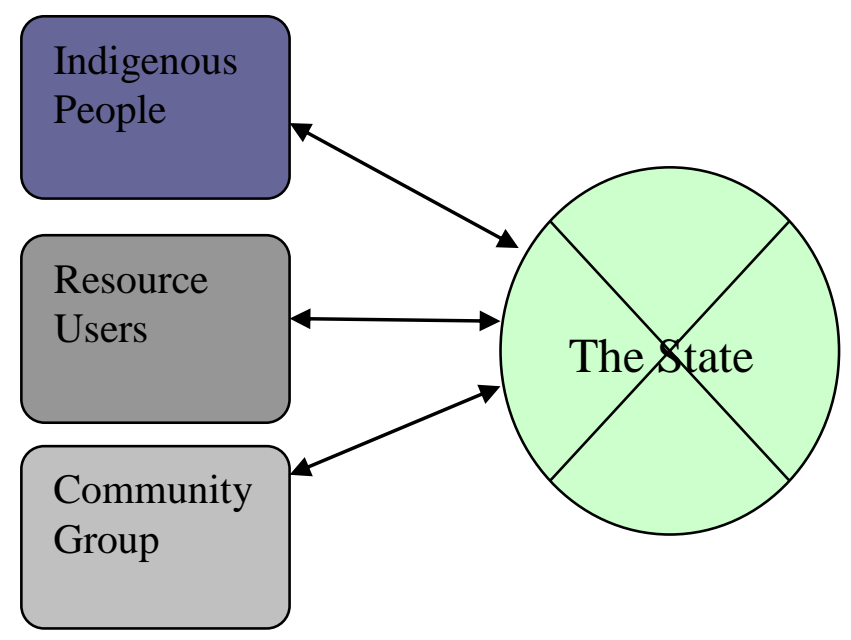

Co-management has also been described as: "a collaborative and participatory process of regulatory decision-making between representatives of user groups, government agencies, research institutions and other stakeholders." 34 The assembly of First Nations ${ }^{35}$ found they could not define co-management and in the interim they suggest the term 'joint management' is used 'because it describes an even playing field between government and First Nations." 36 They further define joint management as follows: ${ }^{37}$

\footnotetext{
${ }^{32}$ Berkes, George and Preston, above n 27 at 2.

${ }^{33}$ Ibid.

${ }^{34}$ S. Jentoft, Co-management - The Way Forward (2002) in K. Geheb and M-T. Sarch (eds.), Africa's Inland Fisheries: the Management Challenge, at 3.

${ }^{35}$ Assembly of First Nations, Co-Management Discussion Paper, at 3.

Available: http://www.afn.ca/uploads/files/env/comanagement_paper.pdf

Accessed: 25/02/2015

${ }^{36}$ Ibid.

${ }^{37}$ Ibid.
} 
In short, joint-management assumes that First Nations and government have equally valid fisheries knowledge and management skills, and that each party is willingness to work jointly and negotiate management decisions and the implementation of decisions.

Borrini-Feyerabend et al. describe co-management as a pluralist approach to managing natural resources "incorporating a variety of partners in a variety of roles, generally to the end goals of environmental conservation, sustainable use of natural resources and the equitable sharing of resource-related benefits and responsibilities." 38 They further identify a number of characteristics of co-management, summarized below: ${ }^{39}$

(1) it seeks democracy in the management of a natural resource;

(2) certain basic conditions must exist for co-management to develop such as freedom and capacity to organise, freedom to express needs and concerns, a non discriminatory social environment, willingness of partners to negotiate and confidence in agreements;

(3) a complex, often lengthy and sometimes confused process, involving frequent changes, surprises, sometimes contradictory information, and the need to retrace one's own steps; and

(4) co-management is the expression of a mature society, which understands that there is no "unique and objective" solution for managing natural resources but, rather, a multiplicity of different options which are compatible with both indigenous knowledge and scientific evidence and capable of meeting the needs of conservation and development.

Berkes too has outlined some "common underpinnings" of conceptualisations of comanagement: ${ }^{40}$

\footnotetext{
38 Borrini-Feyerabend, Above n 31, at 1.

39 Ibid.

${ }^{40}$ Fikret Berkes, Lars Carlsson, “Co-management Concepts and Methodological Implications”,(2005)

Journal of Environmental Management 75, at 67.
} 
1) the concept of co-management is associated with natural resources management;

2) co-management is viewed as some form of partnership between public and private actors; and

3) co-management is not a fixed state process that takes place along a continuum.

Berkes identifies that multi-stakeholder agreements, policy networks, polycentric governance systems and epistemic communities are similar to co-management but lack the inclusion of community resource users and do not possess the 'hall mark of comanagement' which is 'to have at least one strong vertical linkage involving the government and a user group, and some formalised arrangement for sharing power and responsibility." 41 The majority of definitions of co-management need an institutionalised arrangement for intensive user participation, not just ad hoc public participation and consultation. ${ }^{42}$

Across the definitions the common features identified are: co-management involves the management of natural resources, it is a non-static arrangement, it is generally for the purpose of sustainability and the resource is not managed solely by the state: instead, other stakeholders share the management. However, like any term it depends on which angle you are looking at it from: for indigenous people, co-management is intended to be a joint management arrangement but from the state perspective co-management could be seen as a type of consultation. This has the potential for misunderstanding and disappointment, as different parties can have contradictory expectations. In summary it is clear that there is no one single definition: Co-management can be seen as an umbrella term requiring at bare minimum two entities "managing" a natural resource within which there can be numerous variations.

\footnotetext{
${ }^{41}$ Berkes, George and Preston, above n 27, at 5.

42 Ibid.
} 


\section{Types of co-management}

It is recognised that there is a spectrum of co-management, and some divergence on what should be included. Berkes states that there are different "levels of co-management, from informing and consultation, through degrees of power-sharing between the central government and local resource users." 43 By contrast, Tipa ${ }^{44}$ argues that the consultative process included in definitions of co-management by authors such as Berkes ${ }^{45}$ above needs to be excluded from co-management categorisations in order to constitute real or true co-management for indigenous groups. Berkes diagram below shows the different levels of co-management.

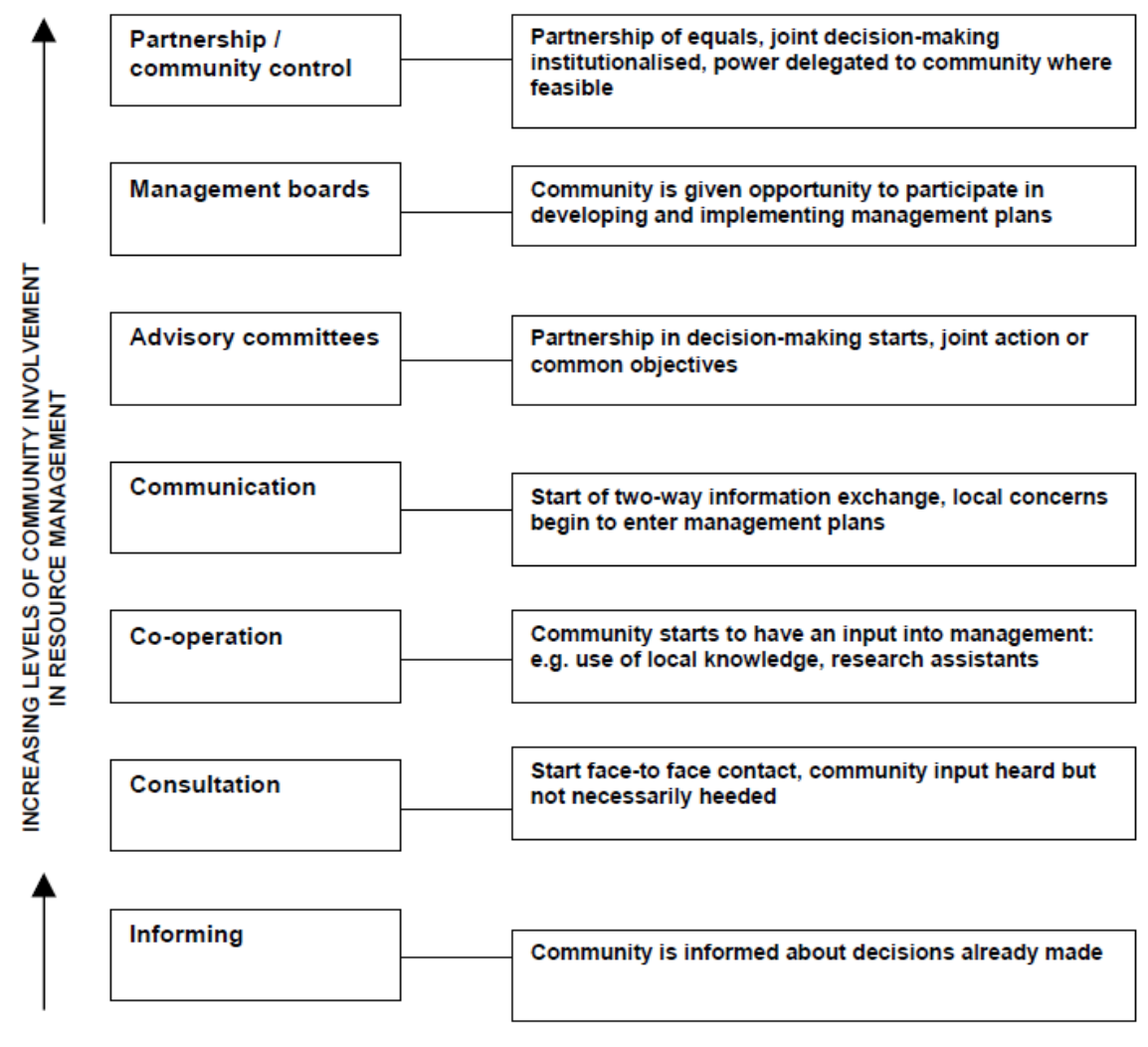

\section{Models of Co-Management}

"Co-management: Case Studies Involving Local Authorities and Māori," Local Government New Zealand, January 2007.

\footnotetext{
${ }^{43}$ Berkes, George and Preston, above $\mathrm{n} 27$, at 3.

${ }^{44}$ Gail Tipa and Richard Welch, above $\mathrm{n} 28$ at 380.

${ }^{45}$ Ibid.
} 
Excluding purely consultation and advisory co-management, there are three types of comanagement that have meaning for Māori as indigenous people: cooperative management, community-based management, and collaborative management. ${ }^{46}$ Cooperative management involves distinct interacting as equal partners. Community based management is described as "people centered" 47 in that it believes a community is primed to understand it own priorities. In this community based management the state remains the dominant party. ${ }^{48}$ Collaborative management is explained as participatory in decision making, and having an emphasis on power sharing. ${ }^{49}$ Tipa believes collaborative management may provide "a level of participation which goes some way to address the aspirations of indigenous communities." 50

Clearly there are many different forms of co-management available, Berkes identifies five examples, summarised below: ${ }^{51}$

1) co-management as an exchange system. This is a relationship between different "spheres of dominance fraternising with each other" exchanging things such as information, goods and services;

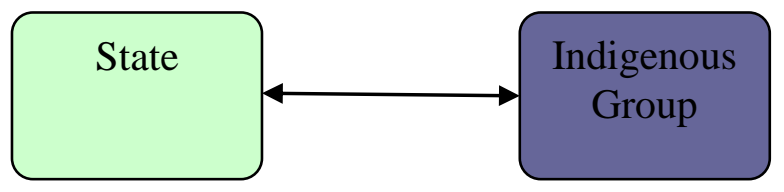

2) co-management as joint organisation. There, for instance, representatives of the State and groups of resource users might form joint management bodies or cooperative units and participate in joint decision making. According to this

\footnotetext{
${ }^{46}$ Gail Tipa and Richard Welch, above n 28, at 388.

${ }^{47}$ Ibid.

${ }^{48}$ Ibid.

49 Ibid

${ }^{50}$ Gail Tipa and Richard Welch, above n 28, at 390.

${ }^{51}$ Fikret Berkes, Lars Carlsson, above n 40, at 68.
} 
image of co-management, each sector keeps its authority and its relative autonomy. This is a "formalised arena for cooperation." 52

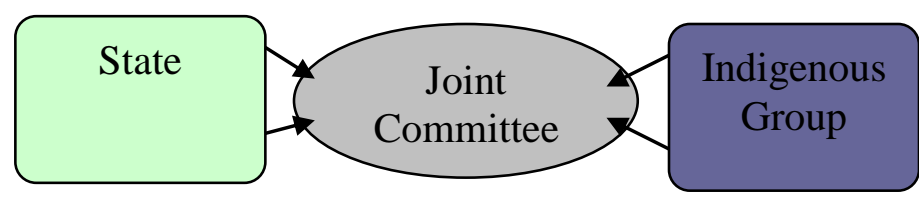

3) co-management as a state-nested system. Here the state is the defacto holder of the legal rights to a certain resource, but certain specific rights have been devolved to local resource users for example the Te Uri Hau settlement in 2002 provided overlay classifications for Manukapua Wildlife Management Reserve and Pouto stewardship area. ${ }^{53}$

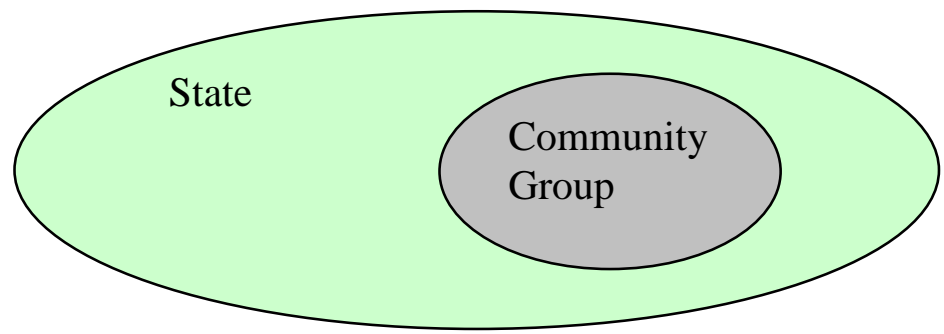

4) co-management as a community-nested system. Where the community or private actors holds the rights in a resource, but the state has authority over parts of its management such as harvesting quota or safety regulations for forestry workers. In New Zealand $94 \%$ of planted forests are owned privately. ${ }^{54}$ An example were the customary harvest of a species is subject to conservation legislation, is the Ngai Tahu settlement; here the ownership and management of the Tìtī Islands from the Crown to Ngāi Tahu was transferred under the Ngāi Tahu Claims Settlement Act 1998. The islands are to be managed as if they are a nature

\footnotetext{
52 Ibid.

53 Te Uri o Hau Settlement Act 2002

${ }^{54}$ Guy Salmon, Matilda Sundström and Kim Zilliacus (2005) "Environmental Management and Natural Resource Allocation Frameworks of New Zealand, Sweden and Finland: A Comparative Description Ecologic Foundation",New Zealand Ecologic Research Report No 1, at 12. Available: http://www.fish.govt.nz/NR/rdonlyres/4CB96899-6B0A-4890-810A183A338AC847/3340/ComparisonResourceManagementFrameworksNZSwedenFinl.pdf Accessed: 25/02/2015
} 
reserve, except for the fact that Ngāi Tahu's rights to sustainably harvest tîtî from the islands are maintained. ${ }^{55}$

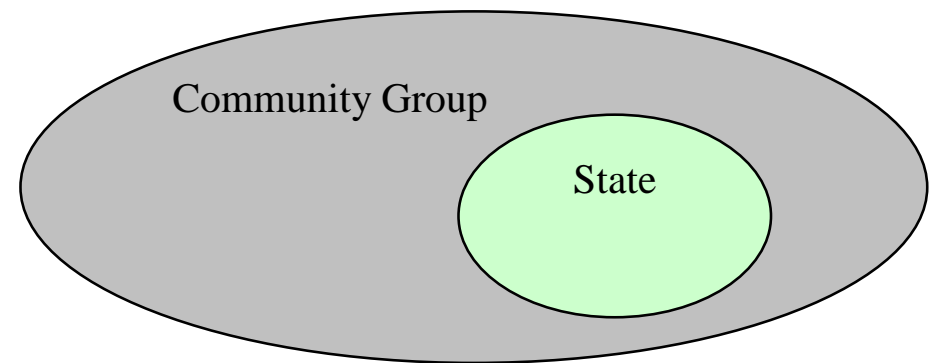

5) A fifth version of co-management is offered in which the state is shown to be fragmented with different faces: ${ }^{.5}$ "the State consists of numerous authorities and agencies that might be associated with different groups and functions of a resource system." 57

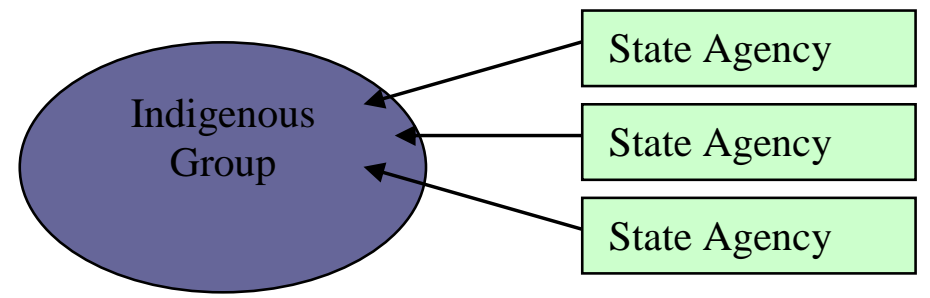

These types of co-management may overlap with one another. ${ }^{58}$

\section{$V$ Adaptive co-management}

Recent literature has viewed co-management arrangements that stand the test of time as evolving into adaptive co-management. ${ }^{59}$ According to Berkes, adaptive management and co-management are moving towards a common ground despite their different lineages. The concept of adaptive management stems from applied ecology whilst the concept of

\footnotetext{
${ }^{55}$ Ngāi Tahu Claims Settlement Act 1998

${ }^{56}$ Fikret Berkes, Lars Carlsson above n 40, at 68.

${ }^{57}$ Ibid.

${ }^{58}$ Ibid.

${ }^{59}$ See: D Armitage, F Berkes, N Doubleday, eds., Adaptive Co-Management, Vancouver, (University of British Columbia Press 2007).
} 
co-management derives from literature on the commons. ${ }^{60}$ Adaptive management and comanagement have common ground in that adaptive management has been defined as "learning by doing" and "consciously incorporates flexibility and the ability to change over time as part of the management arrangement."62 Similarly, comanagement has been viewed as a non-static arrangement: "Co-management evolves over time, very much as a result of deliberate problem-solving." 63 They both exist in an unfixed state. Plummer believes that the natural progression of co-management is to transition into adaptive management: "Maturing co-management arrangements become adaptive co-management in time, through successive rounds of learning-by-doing." This may not be the result of a conscious move towards adaptive management; instead "adaptive co-management is the logical extension of co-management" 65

Bunnell describes adaptive management as "a formal process for continually improving management practices by learning from the outcomes of operational and experimental approaches." 66 Bunnell outlines four elements that are necessary in order to produce a functioning adaptive management arrangement, as follows: ${ }^{67}$

(i) First, it is adaptive, and intended to be self-improving.

(ii) Second, it is a well-designed, formal approach that connects the power of science to the practicality of management.

(iii) Third, it is an on-going process for continually improving management. So the design must connect directly to the actions it is intended to improve; and

\footnotetext{
${ }^{60}$ Fikret Berkes, "Evolution of Co-management Role of Knowledge Generation, Bridging Organisations and Social Learning",(2008) Journal of Environmental Management 90:1692-1002, at 2

${ }^{61}$ Ibid.

${ }^{62}$ Melissa Nursey-Braya, Phillip Rist, Co-management and protected area management: Achieving effective management of a contested site, lessons from the Great Barrier Reef World Heritage Area (GBRWHA) National Centre for Marine Conservation and Resource Sustainability, Locked bag 1370, AMC UTAS, Tasmania, Launceston, Australia, at 1.

${ }^{63}$ Fikret Berkes, Lars Carlsson above n 40, at 70.

${ }^{64}$ Ryan Plummer, Derek Armitage, (2007), "A resilience based framework for evaluating adaptive comanagement: linking ecology, economics and society in a complex world", Ecological Economics 61, at 64.

${ }^{65}$ Ibid.

${ }^{66}$ F.L Bunnell, B.G. Dunsworth, L. Kremsater, D. Huggard, W.J. Beese, and J.S. Sandford, Forestry and biodiversity - learning how to sustain biodiversity in managed forests. UBC Press (in press), 2007, at 1. 67 Ibid.
} 
(iv) Fourth, although experimental approaches can be incorporated into adaptive management effectively, operational approaches and scales are emphasized to permit direct connection to the efforts of managers.

Adaptive management exists on its own as a type of management practised by one entity. It is described as being a continuous cycle: "assessing the present situation, planning some management actions to improve the situation, implementing the planned actions, monitoring (collecting relevant information) and evaluating." ${ }^{68}$ Utilising adaptive management in a co-management scenario means the system can progress step by step, as opposed to the different stakeholders attempting to prescribe the system of comanagement they will operate under from the inception of the arrangement. ${ }^{69}$ This means that parties are not locked into a rigid way of decision-making that may not work as intended in real life. Furthermore, the arrangement is robust enough to respond to change and new challenges by frequently tweaking and realigning itself when and as required. Co-management's ability to adapt is pivotal to its success: "co-management that does not learn often becomes a failed experiment." ${ }^{, 70}$ Adaptive co-management can combine the key feature of co-management; its ability to enfranchise resource users into the management process with the ability to adapt as it progresses enabling the system to improve where needed.

\section{Studying a co-management example}

When studying a co-management arrangement Berkes advocates focusing on the function of a co-management system rather than the theory or the formal structure, believing that the functional side of co-management should be looked at as a continuous problemsolving exercise. ${ }^{71}$ This methodology ties in with the view of co-management as evolving into adaptive management. It means looking at the parties involved as undertaking "a

\footnotetext{
${ }^{68}$ Helen Ross, Cathy J. Robinson and Marc Hockings, Evaluation of Indigenous co-management of natural Resources, School of Natural and Rural Systems Management, University of Queensland, Gatton. CSIRO Sustainable Ecosystems, Brisbane.

${ }^{69}$ Ibid.

${ }^{70}$ Fikret Berkes, Lars Carlsson above n 40, at 75.

${ }^{71}$ Ibid.
} 
process of iterative problem-solving, as in adaptive management." ${ }^{72}$ If co-management is seen as adaptive management the effect on the methodology used is that the researcher should focus on tasks and actions rather than just analysing the formal setup. ${ }^{73}$ Focusing on the formal arrangement can be misleading as this may not represent what its actually happening in practice. $^{74}$ In this paper both the formal agreements and the practical structures that have been put in place are identified to show how the three comanagement partners have given practical effect to the formal arrangement.

\section{Benefits of co-management}

\section{A Utilising strengths of all stakeholders}

A strong feature of co-management is that when the state and other stakeholders are involved in managing a resource then the management entity can utilise the strengths of both the state and the community. For example, the state has access to ecological information, financial resources, and official personnel and data analysis tools, ${ }^{75}$ while the local community may have "knowledge of local conditions, be able to work with local personalities, a variety of groups, demonstrate values and integrity, withstand pressures to compromise ethics."76 Singleton has stated that an ideal form of comanagement combines the strengths of all parties while mitigating their weaknesses. ${ }^{77}$

Local resource users are in a position to be aware of community needs in relation to the resource. They can provide expertise and speak to the veracity of information.

\footnotetext{
72 Ibid

${ }^{73}$ Ibid, at 76

74 Ibid.

75 Suzanne Hoverman Karen Delfau Poh-Ling Tan, Developing alternative management models for Indigenous water plans and strategies in Australia's north. Final report Track NAWFA Social and Cultural Values Project: Sub-project 3 April 2012, at 11.

Available: http://www.environment.gov.au/system/files/resources/03609759-af40-409d-b98dda3193c588d7/files/nawfa-developing-alternative-management-models.pdf Accessed : 25/02/2015

76 Ibid.

77 Singleton, above n 9, at 93.
} 
Government data may have low credibility to resource users - such as fishermen who understand the resource better than a visiting government official. ${ }^{78}$ The ability to communicate the local knowledge of a resource can in turn lead to reduced conflict, as noted by Pinkerton: if a fisherman's livelihood is threatened by information they know to be false they may practise civil disobedience or sabotage. ${ }^{79}$ The more effective and efficient solution is to involve the fisherman in the data gathering. ${ }^{80}$ The local community can also help with policy planning through consultation in order to troubleshoot new government decisions that may impact upon the community. ${ }^{81}$

As Kooiman ${ }^{82}$ identifies as the first governance perspective, governments are not the only entity equipped to manage societal problems: other groups such as NGOs, village councils and volunteer groups can participate in shaping society. This recognition of the role and potential role of non-governmental actors is crucial to the philosophy behind and development of co-management. This has been recognised by the international community at the world summit in Johannesburg in 2002: "We reaffirm the vital role of the indigenous peoples in sustainable development." 83 and "We recognise that sustainable development requires a long-term perspective and broad-based participation in policy formulation, decision-making and implementation at all levels. ${ }^{\prime 84} \mathrm{~A}$ key feature of comanagement is its ability to enfranchise different groups in the administration of natural resources by pooling together experience and expertise from local sources and combining this with the state. ${ }^{85}$ This could involve some or all of the individuals and groups identified by Kooiman ${ }^{86}$ - there is no rigid or set makeup. In involving different resource users co-management can mitigate against individuals acting at cross-purposes from one another without communication. In addition it can avoid duplication of work through

\footnotetext{
${ }^{78}$ Pinkerton, Co-operative Management of Local Fisheries. above n 20, at 13.

${ }^{79}$ Ibid.

${ }^{80}$ Ibid.

${ }^{81}$ Hoverman, above $\mathrm{n} 75$.

82 Jan Kooiman, Maarten Bolvink, , The Governance Perspective, in Jan Kooiman, Maarten Bolvink Svein Jentoft and Roger Pullin (EDs.) Fish for Life: Interactive Governance for Fisheries, 2005, at 15.

83 Johannesburg Declaration on Sustainable Development A/CONF.199/20 at 25.

${ }^{84}$ Ibid, at 26.

${ }^{85}$ Alfonso Peter Castro \& Erik Nielsen, "Indigenous people and co-management: implications for conflict management”. Published in: Environmental Science and Policy Volume 4, No. 4/5, August 2001, at 232.

${ }^{86}$ Kooiman, above n 82.
} 
information sharing, for example one organisation may be responsible for checking water quality at a certain site and communicate the results to the other co-management party.

Pinkerton ${ }^{87}$ identifies seven categories of management relevant to a water resource that can benefit from a co-management arrangement:

(1) data gathering and analysis for the purpose of understanding the state of the resource;

(2) logistical harvesting decisions e.g. who can fish and where, how and when, in order to maintain fish supplies;

(3) Harvest allocation decisions such as how much can be fished by which group, local and non-local groups, what gear can be used to fish in order to allow equitable access;

(4) Protection from habitat or water quality damage by other resource users to preserve the health of the resource;

(5) enforcement of practices regarding harvesting, resource allocation and resource protection;

(6) enhancement and long term planning; and

(7) broad policy decision-making.

This is a wide range of management functions that co-management can potentially improve. Some co-management systems share all of these functions, making them a complete co-management system (in the context of fisheries) while others may not have 'complete' co-management. ${ }^{88}$ Sharing these functions can improve management as some of these functions could be carried out by different entities without communication with potential for duplication, confusion and inefficiency. Clearly addressing different aspects of the seven management processes can result in distinctive co-management arrangements.

\footnotetext{
${ }^{87}$ Pinkerton, Co-operative Management of Local Fisheries. above n 20, at 6.

${ }^{88}$ Ibid, at 7.
} 


\section{B Co-management as an antidote to the tragedy of the commons}

In his 1968 essay, Hardin ${ }^{89}$ describes the tragedy of the commons, where resource users deplete a common or shared resource due to acting rationally in their own self-interest. This can occur when natural resources exist in common property such as fish that migrate through international boundaries known as common pool resources ${ }^{90}$ or common property resources. These resources share two hallmarks: it is extremely difficult or impossible to restrict access to it and each user is capable of subtracting from it to the detriment of other users. ${ }^{91}$ Even though they realise that it is a finite resource they continue to exploit it rather than protecting it for future use: "Ruin is the destination toward which all men rush, each pursuing his own best interest in a society that believes in the freedom of the commons." 92

It is not axiomatic that the tragedy will occur as there is much literature that shows a community can devise institutions to manage a common resource sustainably. ${ }^{93}$ The theory of the tragedy of the commons is tested by Berkes, ${ }^{94}$ who applies its logic to the four main forms of property ownership - open access, private property, communal management and state ownership. They observe that co-management can provide an antidote to the tragedy of the commons as co-management can foster working relationships between individual stakeholders enabling them to act with a common goal and big picture focus rather than individual tunnel vision. Co-management can provide a way in which people with rights to use an area can manage that area to everyone's

\footnotetext{
${ }^{89}$ G Hardin, (1968). "The Tragedy of the Commons". Science 162 (3859), at 1244.

${ }^{90}$ Sara Singleton, "Cooperation or Capture? The Paradox of Co-management and Community Participation in Natural Resource Management and Environmental Policymaking”, (2000), Environmental Politics 9(2): $1-21$, at 2 .

${ }^{91}$ Fikret Berkes, J Bonnie McCay, and James M. Acheson, "The Tragedy of the Commons: Twenty-Two Years Later" Human Ecology, Vol. 18, No. 1, 1990.

${ }^{92}$ Hardin, above $\mathrm{n} 89$.

${ }^{93}$ For further reading on how the tragedy of the commons can be avoided see: The drama of the commons. Ostrom, Elinor (Ed); Dietz, Thomas (Ed); Dolšak, Nives (Ed); Stern, Paul C. (Ed); Stonich, Susan (Ed); Weber, Elke U. (Ed) Division of Behavioral and Social Sciences and Education Washington, DC, US: National Academy Press. (2002). xi 521 pp.; E Ostrom, R Gardner, J Walker Rules, games, and commonpool resources- 1994 University of Michigan 1994; Sara Singleton "Institutions of Governance in Pacific Northwest Salmon Fisheries Commons Problems, Collective Action and Efficiency : Past and Present" Journal of Theoretical Politics 1999 11: 367

${ }^{94}$ Berkes, Bonnie, McCay and Acheson, above n 91.
} 
benefit. Kropotkin believed that cooperation in managing natural resources was a move towards further evolution, he wrote that wherever he saw large numbers of thriving animal life he witnessed "mutual aid and mutual support carried on to an extent which made me suspect in it a feature of the greatest importance for the maintenance of life, the preservation of each species, and its further evolution." 95

Pinkerton has also identified that co-management can increase community development, decentralising decisions to effectively problem solve and create increased participation in democracy. ${ }^{96}$ Co-management for indigenous people can provide a measure of selfdetermination and a way of re-engaging with resources and having some control. ${ }^{97}$ Pinkerton observes that when institutions of control where replaced with European ones this is when societal problems occurred for indigenous peoples. ${ }^{98}$ Co-management may provide the means for indigenous people to regain some control, create new institutions or optimally breath new life and resources into traditional structures.

\section{Potential drawbacks of co-management for indigenous people}

In the absence of full managerial control by indigenous peoples over resources that they have rights to, co-management is one way in which indigenous people can participate in resource management. However Tipa points out that categorisations of co-management can impede indigenous people's engagement with co-management because "most continua incorporate positions which are dimensionally opposite." 99 Tipa refers to difficulties with three common understandings of co-management: co-operative management, collaboration in management and management by community. ${ }^{100}$ Tipa argues that community-based management while seeming likely to provide authority to indigenous people can actually marginalise the indigenous voice.

\footnotetext{
${ }^{95}$ Kropotkin, above n 12 , at 1.

${ }^{96}$ Pinkerton, Co-operative Management of Local Fisheries. above n 20.

${ }^{97}$ Ibid.

98 Ibid

${ }^{99}$ Gail Tipa and Richard Welch, above n 28 at 374

100 Ibid.
} 
The frustration of indigenous people through not being able to participate in a meaningful way in the management of resources is discussed by Booth and Skelton in the context of the impact of industrial development on First Nations in Canada: "To endlessly be asked to participate, to answer similar questions time after time and to see no change, is an impact not easily measured but fundamentally impacting indigenous peoples."101 Their research shows the impact felt by First Nations from the extraction of resources on their traditional lands: "The consequences for First Nations of industrial development upon lands they utilise to maintain their culture are profound. The loss of culture threatens their history, the wellbeing of the current generations and their children's future." 102 The First Nations' elders interviewed in the study believed that unfair demands of the non-indigenous for resources were made on First Nations lands because they are economically disadvantaged and have no political clout. ${ }^{103}$ The challenge is to find a form of co-management that provides actual participation not just consultation or the appearance of involvement. Whilst collaborative arrangements can provide for meaningful indigenous participation, Tipa observes that collaborative arrangements can be made difficult by the need for the state to identify what is 'traditional resource knowledge' and what is non-indigenous community-based knowledge. It can then be problematic to incorporate non-indigenous knowledge while engaging with indigenous knowledge. ${ }^{104}$

The potential for co-management arrangements to actually be counter-productive to indigenous peoples has been noted by Castro: ${ }^{105}$

co-management agreements can set into motion new conflicts or cause old ones to escalate. In practice the result may not be power sharing, but rather a strengthening of the state's control over resource policy, management, and allocation. Instead of contributing

\footnotetext{
${ }^{101}$ Annie L. Booth \& Norm W. Skelton ,"You spoil everything!” Indigenous peoples and the consequences of industrial development in British Columbia Environment, Development and Sustainability A

Multidisciplinary Approach to the Theory and Practice of Sustainable Development Volume 13 Number 4

Environ Dev Sustain (2011), at 698.

102 Ibid, at 697.

103 Ibid, at 699.

${ }^{104}$ Gail Tipa and Richard Welch, above n 28 at 300.

105 Alfonso Peter Castro \& Erik Nielsen, "Indigenous people and co-management: implications for conflict management”,(2001) Environmental Science and Policy Volume 4, No. 4/5, at 229-239
} 
to local empowerment, such arrangements may further marginalise indigenous communities.

It would therefore be important for the parties to an agreement to discuss the potential for conflict from the outset and for conflict resolution steps to be incorporated in negotiations. Castro states: "Conflict management considerations need to be a part of any co-management arrangement." 106

Coombes ${ }^{107}$ has questioned the demand among Māori for co-management acknowledging that it can detract from the focus on land claims and even co-opt their rights: "The acceptability of co-management for Māori is likely to be negligible when co-management is presented as a token solution to their land claims rather than being embedded within broader considerations of historical justice." ${ }^{108}$ There is a risk that the indigenous participation is not real or meaningful.

However, if the co-management sought provides for actual power sharing it could conceivably be a tool for meaningful power, but this can only occur if negotiations are conducted on an equal footing. The parties must be aware of the power compositions that will provide for effective indigenous participation. The dominance of the state agencies over the indigenous group has been identified in case studies by Castro. ${ }^{109}$ Booth believes that indigenous peoples face losing their culture and lifestyle if not protected in the management of natural resources: "the continued social and political acceptance of the impacts of industrial resource extraction upon indigenous cultures and their traditional lifestyles will lead to their disappearance as a people and as a land-based culture." ${ }^{110} \mathrm{~A}$ co-management arrangement that provides for real power sharing could mean that indigenous peoples have the power to ensure their survival.

\footnotetext{
106 Ibid.

${ }^{107}$ Brad Coombes, "Contested conservation legacies and the co-option of Māori resistance through comanagement”, Senior Lecturer, School of Geography and Environmental Science, University of Auckland. 108 Ibid.

${ }^{109}$ Castro and Nielson, above n 105 , at 238

${ }^{110}$ Booth and Skelton, above n 101, at 699
} 
In order to mitigate against these dangers and achieve real power sharing a combination of adaptive management with co-management has been advocated for indigenous peoples working with government. ${ }^{111}$ Robinson argues that a co-learning and co-doing approach is functional and this is an experimental process, identifying 3 key steps for indigenous people in entering into a co-management agreement:

1) preparing for the partnership;

2) negotiating the agreement; and

3) implementing the agreement through learning by doing. ${ }^{112}$

It appears crucial that the indigenous group is well prepared in order to negotiate an agreement that will give them effective participation in the resource. In addition, it is advantageous for indigenous peoples to practice adaptive co-management or learning by doing.

\section{Summary}

Although forms of co-management have existed for centuries the modern emergence is linked to the collapse of the fisheries and since then it has evolved as a means to give effect to indigenous rights to natural resources, while retaining state involvement. Comanagement can have benefits such as utlising the knowledge and technology of the community and the state. There is a wide variance in types of co-management and the level of engagement achieved by the non-state group, this can range from joint decisionmaking, through to consultation with no say in policy or outcome. There are a number of things that indigenous people need to be aware of prior to entering onto a co-management arrangement especially if they are doing so in recognition of their rights or extinguishment of a claim; the redress needs to be real and provide for equal or greater management rights than the other co-management partners.

\footnotetext{
${ }^{111}$ Helen Ross, Cathy J. Robinson and Marc Hockings, "Evaluation of Indigenous co-management of natural resources", School of Natural and Rural Systems Management, University of Queensland, Gatton. CSIRO Sustainable Ecosystems, Brisbane ${ }^{112}$ Ibid.
} 


\title{
Chapter Two: History of the Te Arawa Lakes
}

\author{
Te Arawa Proverb \\ Mai Maketū ki Tongariro ... \\ Ko Te Arawa te waka \\ Ko Te Arawa māngai-nui ūpoko tū-takitaki. \\ From Maketū to Tongariro ... \\ Te Arawa the canoe \\ Te Arawa the determined people. ${ }^{113}$
}

\section{Historical background}

The Te Arawa iwi (tribe) migrated to Aotearoa from Hawaiki sometime in the $14^{\text {th }} \mathrm{c}$ entury. ${ }^{114}$ On Hawaiki, Te Arawa was called Nga-rakau-tapu-a-Atuamatua. ${ }^{115}$ Nga-rakautapu-a-Atuamatua left Hawaiki in part due to a war with a neighboring tribe; this war was set in motion by a dispute over the killing of their chief Houmaitawhiti's dog by Chief Uenuku. ${ }^{116}$ This incident led to an invasion of Nga-rakau-tapu-a-Atuamatua lands by Uenuku's tribe and Nga-rakau-tapu-a-Atuamatua made the decision to leave Hawaiki. ${ }^{117}$ In addition to the tribal warfare driving them away, oral traditions have recounted that

\footnotetext{
${ }^{113}$ Paul Tapsell, Te Arawa Proverb ‘Te Arawa - Settlement and migration', Te Ara - the Encyclopedia of New Zealand,

Available: http://www.TeAra.govt.nz/en/te-arawa/page-2

Accessed : 25/02/2015

114 J.B.W Roberton, "The Role of Tribal Tradition in New Zealand Prehistory", The Journal of the Polynesian Society, Vol. 66, No. 3 (September 1957), pp. 249 - 163

115 Nga-rakau-tapu-a-Atuamatua renamed themselves 'Te Arawa' after the shark that rescued their canoe during their voyage, Donald Murray Stafford, Te Arawa: A History of the Arawa People, Reed 1967, Indiana University

${ }^{116}$ Ibid.

117 Ibid.
} 
Hawaiki was struggling to provide enough land and food to sustain its population, ${ }^{118}$ adding to the appeal of migration.

Tamatekapua was the son of Chief Houmaitawhiti and he led the Arawa waka (canoe) to New Zealand. The powerful tohunga Ngatoroirangi was also on board. ${ }^{119}$ Some historians believe that the Tainui and Te Arawa waka were actually two hulls forming a single waka. ${ }^{120}$ However according to Don Stafford, best evidence suggests that Te Arawa and Tainui were two separate waka. ${ }^{121}$ Exact figures of the Te Arawa crew are not known but according to John Grace, ${ }^{122}$ there were more than one hundred people aboard the Te Arawa waka.

The Te Arawa waka made landfall at the entrance of the Kaituna river and the bow of the waka was tied to a rock named Tokaparore. ${ }^{123}$ The tohunga Ngatoroirangi was the first passenger to disembark and he commenced rituals underneath a flowering pohutakawa tree. ${ }^{124}$ The passengers claimed the land from Maketu in the south to Katikati in the north. ${ }^{125}$ According to the Te Arawa Lakes Trust, the Te Arawa lands "traditionally covered reaches from a small village named Maketu on the eastern seaboard to Tongariro mountain in the central North Island." ${ }^{126}$ Therefore the Te Arawa tribal rohe ranges from Maketu to Mount Tongariro. ${ }^{127}$

The children and grandchildren of the Te Arawa waka captain, Tamatekapua, were prominent explorers and tribal leaders. Tamatekapua's son Kahumatamomoe along with his nephew Ihenga discovered and named many of the Te Arawa Lakes, including Lake

\footnotetext{
118 Ibid.

119 Tapsell, above n 113.

${ }^{120}$ Stafford, above n 115.

121 Ibid.

${ }^{122}$ John Te H. Grace A. H. \& A. W. Reed, Tuwharetoa, 1960.

123 Tapsell, above n 113, at 3 .

124 Ibid.

${ }^{125}$ Stafford, above n 115.

${ }^{126}$ About the Te Arawa Trust

Available: http://www.tearawa.iwi.nz/about-trust

Accessed: 06/07/2014.

127 Tapsell, above n 113, at 3.
} 
Rotorua and Lake Rotoiti. ${ }^{128}$ Rangitihi, a great grandson of Tamatekapua was a tribal leader, and descendants of his eight children gradually became major kin groups that are known as "Nga pu manawa e waru o Te Arawa" - "The eight beating hearts of Te Arawa." 129 The sons of Rangitihi led the majority of the Te Arawa iwi inland from the coast where they settled at the geothermal lakes. ${ }^{130}$

These lakes became the Te Arawa Lakes: Rotorua / Rotorua-nui-a Kahumatamomoe, Rotoiti/Te Roto- Whaiti-i-kite-ai-a-Ihenga-i-Ariki- ai- a Kahumatamomoe,Rotoehu, Rotomä, Ökataina / Te Moana i kataina a Te Rangitakaroro, Ökareka, Rerewhakaaitu, Tarawera, Rotomahana, Tikitapu, Ngähewa, Tutaeinanga, Ngäpouri/Opouri and Ökaro/Ngakaro.

\section{Relationship of Te Arawa with the lakes}

To Te Arawa, the lakes were taonga, and their relationship to the lakes and environs was and continues to be the foundation of their identity, cultural integrity, wairua, tikanga and kawa."131

Te Arawa established their pa (settlements) and kainga (homes) at the Te Arawa lakes. ${ }^{132}$ These lakes were rich in resources for the tribe - native fish and wildlife provided food and the surrounding bush provided shelter. ${ }^{133}$ Further practical resources included freshwater, economic trade, and koha:

\footnotetext{
128 Tapsell, above n 113, at 3.

129 Tapsell, above n 113, at 3.

${ }^{130}$ Rāwiri Taonui. 'Ngā waewae tapu - Māori exploration - Te Arawa explorers', Te Ara - the Encyclopedia of New Zealand, updated 22-Sep-12

Available: http://www.TeAra.govt.nz/en/nga-waewae-tapu-Māori-exploration/page-5

Accessed: 06/07/2014

131 Te Arawa Lakes Settlement Act 2006, Public Act Date of assent 2006, preamble.

132 Anaru Ririwai Rangiheuea, The Te Arawa Tribe's Relationship with its lakes, Available: http://docs.niwa.co.nz/library/public/0473111322.pdf\#page=94

Accessed : 05/04/2014

${ }^{133}$ Te Arawa Lakes Settlement Act, above n 131.
} 
From time immemorial the Arawa had been accustomed to drawing on the lakes which abound in the district for a considerable and important part of their food supply. Inanga, toitoi, koura and kakahi had been taken for centuries and apart form adding a relish to other foodstuffs has also been an important element in bartering with Māoris in other districts for sea fish, forest foods and valuable gifts etc. ${ }^{134}$

The lakes were also used by Te Arawa for transport and trade routes; Lake Okataina was an important link when canoes were carried from Lake Tarawera to Lake Okataina. ${ }^{135}$ The resources of the lakes were utilized in a traditional manner - Huhana Bubbles Mihinui of Te Arawa describes the iwi's approach to resource management: ${ }^{136}$

There was no management without discipline. Resource sustainability meant our own survival. The geothermal, the weaving and the food resources were protected or utilized depending on need. Conservation is a very important part of resource management, but exploitation is also.

The iwi had overarching authority to place restrictions on resource use but individuals had certain use rights: ${ }^{137}$

each tribe has its own rohe. It really is a simple matter of respect, which is an inherent part of the other side of the coin of 'rights or 'ownership' and that is responsibilities. Of resources that lie outside our rohe, we would not help ourselves to any, or at any time even when the resources may appear to be 'moumou noa iho' or plentiful. That may be the case but as outsiders, we are not to know what local management regimes are in place and whether a resource area is being left to rejuvenate or whatever.

\footnotetext{
134 Te Arawa Māori Trust Board 1924 - 1974, A review of its first 50 years, at 8.

${ }^{135}$ G.R. Fish, Limnoligical Conditions and Growth of Trout in three lakes near Rotorua, Marine Department, Rotorua, at 2.

${ }^{136}$ Merata Kawharu [ed], Whenua Managing our Resources, Hutia te Rito o te Harakeke, A flaxroot Understanding of Resource Management, Huhana Bubbles Mihinui, 2002, Reed Publishing.

137 Ibid.
} 
This system was very different to the English property system where property was allocated on a geographical basis by breaking the land into portions that were owned by a single person, who had the right to consume all the resources that were provided by that segment. ${ }^{138}$ For Māori, the tribe as a whole had the overarching indefeasible property right over their rohe, including the resources that area possessed, and different rights were given to individuals on a functional basis. Individuals had the right to use a certain resource in a particular designated area. For example, Banner elaborates that one family may have the right to use a certain tree for berry picking whilst another can use that same tree for fowling. ${ }^{139}$ The fundamental difference is that English rights to resources were exercised by one individual over a single piece of land. Rutene Irwin describes the resource use of eels as a child: ${ }^{140}$

The streams and rivers nearby were full of eels, which were a major part of our diet. We each had our own special holes and would feel the eels to decide whether they were big enough to pull out.

The freshwater lakes also held a deeper, spiritual value as a source of spiritual guidance and healing: ${ }^{141}$

In times of crisis, my people would go to the lake or river at dawn to seek healing. They would face the rising sun, pat the water, sprinkle themselves, call on their tupuna (ancestors) and draw inspiration and healing from it.

This spiritual value reflects the Māori view of water. Māori believe that water needs to be cared for in the manner of caring for a human, creating a reciprocal relationship whereby both human beings and water operate to ensure mutual survival and sustainability. The connection of Māori to water has been acknowledged in Waitangi tribunal reports such as

\footnotetext{
138 Stuart Banner, "Two Properties, One Land: Law and Space in Nineteenth-Century New Zealand" (1999) Law \& Social Inquiry Vol. 24, No. 4807.

139 Ibid.

${ }^{140}$ Rutene Irwin and John Ruru "Mangatu”, Merata Kawharu [ed], Whenua Managing our Resources, ,2002, Reed Publishing.

${ }^{141}$ Rangiheuea, above n 132, at 94.
} 
the Te Ika Whenua river report wai 212, which stated "Claimant evidence shows that rivers were and still are a taonga that provides material and spiritual sustenance and a strong continuing bond. The people belong to the river and the river belongs to the people." 142

Māori believe that water has an intrinsic life force that travels within it and resides inside human beings and plants. ${ }^{143}$ Māori have a variety of terms to describe different types and characteristics of water, as listed below: ${ }^{144}$

Waiariki - Collective term for geothermal hot water. Water of the gods.

Wai horoi - Water that is used to bathe in or wash clothes or other personal possessions.

Wai Inu/Wai Unu - Water that is used only for drinking. Drinking water is not taken from a source that is used for washing unless there is no alternative, and then it should be taken from the stream at a specific time of the day when washing of clothes or bathing is not permitted.

Waikino - Water that has been degraded or altered to such an extent that it can cause harm or water that conceals hidden dangers. This can be very fast flowing, Life-threatening water or water that is causing health problems.

Wai makariri/Wai matao - Cold water, mainly cold fresh water.

Wai - Water that runs freely and has no particular qualities. Ordinary water. Water used for drinking, or from which food is gathered, wai, is never allowed to be contaminated by human waste. Therefore any untreated or improperly treated

\footnotetext{
142 Te Ika Whenua River Report, (Wai 22, 1998)

143 Jim Williams, (1997), "Mauri and the Traditional Māori Environmental Perspective" Environmental Perspectives, No. 14, March/April. 144 Ibid.
} 
sewage cannot be allowed to get into these waters. To do so would lower the spiritual nature of it and affect mana of the people who use the water.

Waimate - Water that has lost its mauri or life force. It is dead, damaged or polluted with no ability to sustain life. It can contaminate other living or spiritual things.

Waiora - Purest form of water, a source of well-being and life. Used for cleansing from sickness and to create positive energy. This water can become waitapu. contains the source of life and well being. It is used for sacred rituals to sanctify and counteract evil.

Waipiro - Slow moving, slack water, often water that smells, such as repo (swamps). These waters are still able to provide many sources such as rongoa (medicine), dyes for weaving, harakeke and tuna (eels) for kai (food) and homes for many living organisms. Also a colloquial term for alcoholic beverages.

Waipuke - Flood or flood waters.

Wairere - Waterfall.

Waitai - The sea, surf or tide. Used to distinguish seawater from fresh water.

Waitapu - Water that has had a 'tapu' imposed upon it. Water that is used for special rituals such as baptism or purification ceremonies.

Waiparu - Unclean water.

Waitupapaku - Water used for cleansing bodies and bones before traditional burial. 
Wairua - The spiritual essence of water.

Māori believe water bodies such as rivers, lakes and wetlands, have their own mauri, and it is important to protect their mauri from pollution, degradation and damage. ${ }^{145}$ As described by Tredegar Rangiātea Delamere Hall: "Māori perceive water as an integral part of life as it possesses its own mauri, mana and wairua. Water is also perceived as a taonga, gifted by tūpuna for the benefit and use of their descendants." ${ }^{146}$ Given the status of water in Māori custom there are protocols and ways of interacting with water that reflect these beliefs; for instance taking large portions of a river's flow may be considered to be taking part of its body. It is not only the ecosystems that the river supports that are affected, it is the river itself. The river has value beyond its immediate uses, and should not be downgraded as people seek to improve life for themselves. ${ }^{147}$

Traditionally Māori were responsible for the care and protection of bodies of water, maintaining the health of water was essential to the survival of the spirit that lived within the water $:^{148}$

According to Māori, all rivers and lakes contain a taniwha (serpent), which acts as a spiritual guardian of that water source. Sadly, however, the taniwha would cease to exist if the waters became contaminated. Tangata whenua are bestowed with the responsibility of kaitiakitanga to manage water not as a resource, but as a vital source of life.

Te Arawa was responsible for protecting the life force and spiritual guardians of all the lakes within their rohe, different hapu of Te Arawa such as Ngati Rangiwewehi had their own territory within different lakes, for instance lake Rotorua was divided

\footnotetext{
145 T.K.K.B. Morgan, Te Arawa, Ngati Pikiao, Ngati Kahungunu, Kai Tahu “An indigenous perspective on water recycling Civil and Environmental Engineering," The University of Auckland, New Zealand2005

${ }^{146}$ Tredegar Rangiātea, Delamere Hall, Restoring the flow: Challenging the existing management frameworks to integrate Mātauranga Māori, By A thesis submitted in fulfilment of the requirements for the degree of Master of Social Sciences

${ }^{147}$ Cultural values of waterways and the Cultural Health Index (CHI) Available: http://mfe.govt.nz/publications/water/cultural-health-index-jun03/ Accessed: 28/02/2015

${ }^{148}$ Rangiheuea, above n 132.
} 
up from Mokoia Island in a pie chart formation. ${ }^{149}$ Each lake has its own characteristics and each was in different states of ecological damage when Te Arawa regained some management functions in the 2004 settlement.

\section{Outline of the Te Arawa Lakes}

Below is an outline of the characteristics for each of the lakes that form the Te Arawa Lakes group.

Map: Te Arawa Lakes

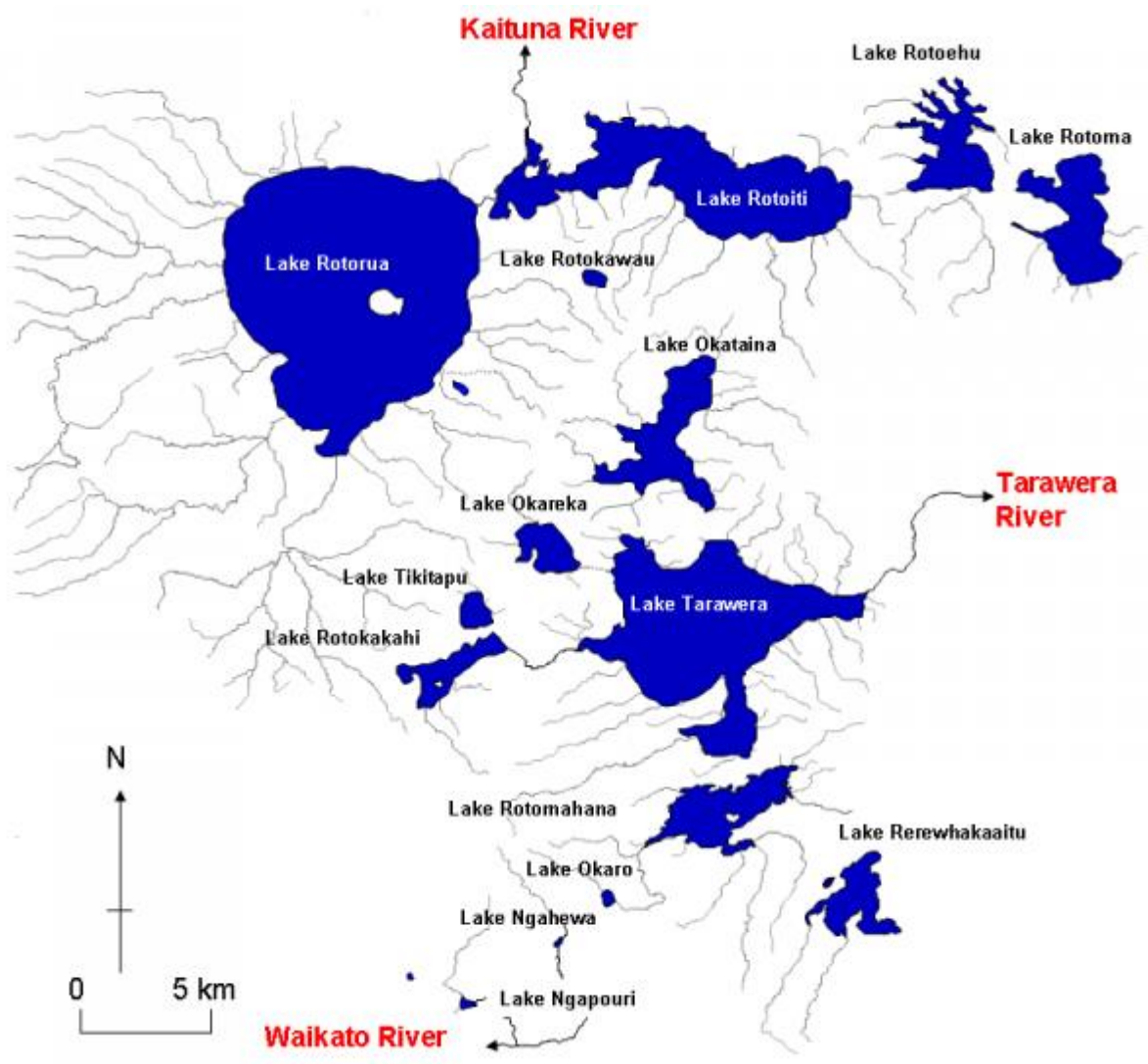

${ }^{149}$ Don Stafford, Landmarks of Te Arawa, Reed Books, Auckland 1994, at 197 
Image from NIWA www.niwa.co.nz ${ }^{150}$

\section{A Lake Rotorua-nui-a-Kahumatamomoe}

Lake size: 8060 ha

Catchment area: 50060 ha

Elevation: $280 \mathrm{~m}$

Average depth: $11 \mathrm{~m}$

Deepest point: $45 \mathrm{~m}$

Formed: 140,000 years ago ${ }^{151}$

The largest of the Te Arawa Lakes was named Rotorua-nui-a-Kahumatamomoe by Ihenga after his father in law and uncle Kahumatamomoe. ${ }^{152}$ Lake Rotorua is the most prolific trout fishing area in New Zealand. ${ }^{153}$ The island in the middle of the lake, called Mokoia, was originally Te Motu-tapu-a-Tinirau, but came to be Mokoia when Uenukukopako killed Arorangi by striking his Ko (digging stick) across Arorangi's Moko (Tattoo). ${ }^{154}$ Mokoia Island is known for the legend of Hinemoa who swam across to the island to meet with her lover Tutanekai. ${ }^{155}$

\section{B Lake Rotoiti}

\footnotetext{
${ }^{150}$ Map of the Rotorua Lakes

Available:http://www.niwa.co.nz/our-science/freshwater/our-services/freshwater-species-and-habitatmanagement/te arawa lakes

Accessed: 02/02/2014

${ }^{151}$ State of the Rotorua/Te Arawa Lakes 2009-2010. An update on the current state of the Rotorua/Te Arawa Lakes and what actions are being taken to protect and restore them at 21 .

Available: http://www.boprc.govt.nz/media/33625/RotoruaLakes-100827-FULLREPORT.pdf Accessed : 05/07/2015

152 Don Stafford, Landmarks of Te Arawa, Reed Books, Auckland 1994

153 State of the Rotorua/Te Arawa Lakes 2009-2010 An update on the current state of the Rotorua/Te Arawa Lakes and what actions are being taken to protect and restore them

${ }^{154}$ Stafford, Landmarks of Te Arawa, above n 149

155 State of The Rotorua Te Arawa Lakes, Above n 151.
} 
Lake size: 3400 ha

Catchment area: 12160 ha

Elevation: $279 \mathrm{~m}$

Average depth: $31 \mathrm{~m}$

Deepest point: $93.5 \mathrm{~m}$

Formed: 8500 years ago ${ }^{156}$

Lake Rotoiti has been described as 'pure water'. ${ }^{157}$ It was discovered by Ihenga when exploring, his dog Potakatawhiti vomited whitebait after disappearing. Ihenga named the lake Rotoiti, or Te Roto-Whaiti-i-kite-ai-a-Ihenga-i-Ariki-ai-a Kahumatamomoe. Lakes Rotorua and Rotoiti are linked via the Ohau channel and therefore the water quality of Lake Rotorua directly affects Lake Rotoiti. ${ }^{158}$

\section{Lake Rotoehu}

Lake size: 800 ha

Catchment area: 4710 ha

Elevation: $295 \mathrm{~m}$

Average depth: $8 \mathrm{~m}$

Deepest point: $13 \mathrm{~m}$

Formed: 8500 years ago 159

The word Rotoehu means "turbid" or murky waters. This meaning suggests that the lake may have always had poor visibility and murky waters. ${ }^{160}$ The lake is shallow and suffers from high algae and nutrients levels. Te Arawa had settlements and pa around Lake Rotoehu and there is an island below the waterline. ${ }^{161}$

\footnotetext{
${ }^{156}$ Ibid.

${ }^{157}$ Stafford, Landmarks of Te Arawa, above n 159

${ }^{158}$ State of the Rotorua/Te Arawa Lakes 2009-2010, above n 151.

${ }^{159}$ Ibid.

${ }^{160}$ Ibid.

${ }^{161}$ Ibid.
} 


\section{Lake Rotomā}

Size 1110 ha

Catchment area: 2810 ha

Elevation: $316 \mathrm{~m}$

Average depth: $37 \mathrm{~m}$

Deepest point: $83 \mathrm{~m}$

Formed: 8500 years ago ${ }^{162}$

Lake Rotomā means "lake of exceptionally clear water". ${ }^{163}$ The lake currently has the best water quality of all the Rotorua lakes, with water clarity of around 11 meters. There are four buoys near the centre of the lake that show the site of a submerged Māori pa. ${ }^{164}$

\section{E Lake Ōkataina}

Lake size: 1080 ha

Catchment area: 6290 ha

Elevation: $311 \mathrm{~m}$

Average depth: $39 \mathrm{~m}$

Deepest point: $79 \mathrm{~m}$

Formed: about 7000 yrs ago 165

Okataina means "the lake of laughter." It was named when a Māori warrior mistook it for an ocean, and was originally called Te Moana-i-kataina-a-Te Rangitakaroro, which means "The ocean where Te Rangitakaroro laughed."166

\footnotetext{
162 Ibid.

${ }^{163}$ Ibid.

${ }^{164}$ Ibid.

165 Ibid.

${ }^{166}$ Ibid.
} 


\section{F Lake Tikitapu}

Lake size: 150 ha

Catchment area: 570 ha

Elevation: $415 \mathrm{~m}$

Average depth: $18 \mathrm{~m}$

Deepest point: $27.5 \mathrm{~m}$

Formed: 13,500 years ago ${ }^{167}$

Lake Tikitapu is named after an incident where the daughter of a high born chief's

Tikitapu (sacred pounamu) necklace fell into the waters of the lake. ${ }^{168}$

\section{G Lake Ōkareka}

Lake size: 340 ha

Catchment area: 1980 ha

Elevation: $355 \mathrm{~m}$

Average depth: $20 \mathrm{~m}$

Deepest point: $34 \mathrm{~m}$

Formed: 19,000 years ago ${ }^{169}$

Lake Okareka means "the lake of sweet food" as Te Arawa grew kumara around the outside of the lake. ${ }^{170}$

\section{H Lake Tarawera}

Lake size: 4130 ha

Catchment area: 14520 ha

Elevation $298 \mathrm{~m}$

Average depth: $50 \mathrm{~m}$

\footnotetext{
${ }^{167}$ Ibid.

168 Ibid.

${ }^{169}$ Ibid.

170 Ibid.
} 
Deepest point: $87.5 \mathrm{~m}$

Formed: 5000 years ago ${ }^{171}$

Lake Tarawera means 'Burnt Spear'. Te Arawa lived at Lake Tarawera with small settlements and pa along the lakeside. ${ }^{172}$

\section{Lake Rotomahana}

Lake size: 900 ha

Catchment area: 8370 ha

Elevation: $339 \mathrm{~m}$

Average depth: $60 \mathrm{~m}$

Deepest point: $125 \mathrm{~m}^{173}$

Rotomahana means "warm lake." Lake Rotomahana had the pink and white terraces a major tourist attraction until they were lost in the Tarawera eruption in 1886.

\section{J Lake Rerewhakaaitu}

Lake size: 530 ha

Catchment area: 5290 ha

Elevation: $435 \mathrm{~m}$

Average depth: $7 \mathrm{~m}$

Deepest point: $15 \mathrm{~m}$

Formed: 700 years ago ${ }^{174}$

Rerewhakaaitu means the lake of "wandering spirits." The land surrounding this lake, rich with the volcanic soils from the Tarawera eruption, was the last of the developed farming areas of the Rotorua District.

\footnotetext{
${ }^{171}$ Ibid.

${ }^{172}$ Ibid.

${ }^{173}$ Ibid.

${ }^{174}$ Ibid.
} 


\section{K Lake Ōkaro (also known as Ngākaro)}

Lake size: 31 ha

Catchment area: 367 ha

Elevation: $419 \mathrm{~m}$

Average depth: $12.5 \mathrm{~m}$

Deepest point: $18 \mathrm{~m}$

Formed: 800 years ago

The origins of Lake Ōkaro/Ngakaro name are unknown. The lake is very popular for waterskiing but the water quality is very poor. ${ }^{175}$

\section{Lake Ngāhewa}

Lake size: $8.40 \mathrm{ha}$

Lake Ngāhewa was formed from a hydrothermal explosion crater. The majority of the catchment has been converted from native bush to pastureland. ${ }^{176}$

\section{The environmental damage done to the Te Arawa Lakes ecology through the Crown's introduction of foreign fish species and nutrient input}

The ecology and environmental health of the Te Arawa Lakes was damaged in a variety of ways during the stewardship of the Crown; ${ }^{177}$ specifically, the introduction of foreign trout led to the destruction of the indigenous species and the discharges from farming

\footnotetext{
${ }^{175}$ Ibid.

${ }^{176}$ D. I. Forsyth and R. H. S. McColl Limnology of Lake Ngahewa North Island, New Zealand Ecology Division, Department of Scientific and Industrial Research, Taupo, New Zealand (Received 16 January 1975)

${ }^{177}$ Prior to and after the 1922 Agreement the Crown and, through legislation, local government assumed responsibility for regulation of activities on the lakes and lakebeds. Throughout the twentieth century the Crown and local authorities assumed increasing responsibility for discharges impacting upon the lakes.
} 
related chemicals and fertilizers polluted the freshwater to the extent that some lakes are unsafe for swimming. ${ }^{178}$

\section{A Destruction of the Kōaro}

In the 1880s rainbow and brown trout were introduced under the Salmon and Trout Introduction Act $1867^{179}$ into the Te Arawa Lakes by acclimatisation societies, local bodies and government departments. ${ }^{180}$ Prior to the introduction the dominant fish was the indigenous species called kōaro. ${ }^{181}$ Kōaro were:

a significant fisheries resource for Māori, who harvested adults (kōkopu) and juveniles (inanga) using nets and traps crafted from flax and native woods. As a major source of protein, the kōaro fisheries were an integral part of tikanga and were a taonga species for Te Arawa. ${ }^{182}$

Te Arawa maintains that they did not consent to and were not consulted concerning the introduction of foreign fish (trout included) to the lakes. ${ }^{183}$ The kōaro became the prey of the trout and the native fisheries collapsed, with kōaro existing at a low unsustainable level. ${ }^{184}$ The kōaro were further decimated by the introduction of smelt in the 1930s which dominated the supply of plankton and preyed on kōaro larvae. ${ }^{185}$ Kōaro was either scarce or non-existent, only surviving where the trout could not reach and native bush

\footnotetext{
${ }^{178}$ Parliamentary Commissioner for the Environment. 2006. Restoring the Rotorua Lakes: The ultimate endurance challenge. Wellington: Parliamentary Commissioner for the Environment.

${ }^{179}$ Carl Walrond. 'Acclimatisation - Early acclimatisation societies', Te Ara - the Encyclopedia of New Zealand, updated 13-Jul-12

Available: http://www.TeAra.govt.nz/en/acclimatisation/page-2

Accessed: 02/07/14

${ }^{180}$ Te Arawa Deed of Settlement 2004

${ }^{181}$ Restoring Kōaro in the Rotorua Lakes Science Centres: Freshwater and Estuaries, Te Kūwaha NIWA contacts: Dave Rowe. External people involved: Roku Mihinui (Te Arawa Lakes Trust)era Smith (Te Arawa Lakes Trust), Matt Bloxham (BOPRC)

Available: http://www.niwa.co.nz/freshwater-and-estuaries/projects/restoring-k\%C5\%8Daro-in-therotorua-lakes

Accessed : 02/07/14.

${ }^{182}$ Restoring Kōaro in the Rotorua Lakes, above n 181.

183 Te Arawa Deed of Settlement, 2004

${ }^{184}$ Restoring Kōaro in the Rotorua Lakes, above n 181.

185 Ibid.
} 
canopy had not been cleared. Once this bush was removed for farming the kōaro lost their last refuge and disappeared completely. ${ }^{186}$

The destruction of the kōaro resource caused hardship for Te Arawa. ${ }^{187}$ It was not just the obvious, direct loss of a valuable food source but the further impacts on the iwi such as their ability to provide hospitality, koha and use this resource for economic trading. ${ }^{188}$ Additional damages were inflicted when the Crown introduced a fishing license regime in 1888, under which Te Arawa had to pay for a license to fish trout and foreign species. This meant Te Arawa could not use traditional fishing methods such as net setting and, with the koaro not plentiful, Te Arawa had to pay to access the introduced fish.

In the Te Arawa Deed of Settlement the Crown acknowledged that: ${ }^{189}$

1) The introduction of exotic fish species had significantly depleted the indigenous species upon which Te Arawa depended for food, hospitality, trade and koha;

2) Te Arawa had petitioned the Crown for several years concerning the depletion of the indigenous species and access to the new species;

3) some Te Arawa had been prosecuted for fishing without a license in the lakes during this time; and

4) The Crown's failure to legislate for a sufficient number of licenses for Te Arawa in 1908 (when the Crown promoted legislation to address the problem of hardship) was in breach of Te Tiriti o Waitangi/the Treaty of Waitangi and its principles.

\footnotetext{
186 Ibid.

187 Te Arawa Deed of Settlement 2004

188 Ibid

189 Ibid
} 


\section{B Impact of land clearing and pastoral farming}

From the late $19^{\text {th }}$ century the land surrounding the Te Arawa Lakes was cleared for farming and septic tanks where installed. ${ }^{190}$ The lakes then had an increase in nutrients flowing from the catchment to the lakes; this caused excess nitrogen and phosphorous which led to the growth of blue-green algae in the lakes. ${ }^{191}$ The intensification of farming meant that the nutrient flow overwhelmed the balance of the lakes water with serious environmental effects. ${ }^{192}$ There are currently 26 dairy farms in the Rotorua catchment alone. ${ }^{193}$ As a result of the intensification of farming, water quality in the Rotorua Lakes has been "declining for 30 to 40 years, and toxic blue-green algal blooms have become a serious problem in some of the lakes." 194

In addition, from 1900 onwards sewage was allowed to flow into the Te Arawa Lakes. This has been identified as one of the major sources of nutrients into the water; ${ }^{195}$ one of the dangers of excessive nutrient inputs is the acceleration of eutrophication, which without additional nutrients entering the body of water, is a very slow natural process of a water body aging. The conversion of catchment areas from native bush into pastoral grazing areas has been identified as hastening the eutrophication process $-90 \%$ of Lake Ōkaro's catchment is farmland and it is the most polluted of the Te Arawa Lakes. ${ }^{196}$ It has a significant algae problem due to the levels of nitrogen and phosphorus nutrients which have increased over several decades. ${ }^{197}$ Indeed, the impacts of farming and the clearing of native vegetation have affected the condition of lakes throughout New Zealand - $40 \%$ of New Zealand's 700 shallow lakes are now eutrophic and the majority

\footnotetext{
190 Ibid, s 7.

${ }^{191}$ D. P. Hamilton, M. J. Landman Preface: Lake restoration: an experimental ecosystem approach for eutrophication control Received: 10 November 2010 / Accepted: 12 November

192 J.M. Abell, D.P. Hamilton \& J. Paterson (2011), Reducing the external environmental costs of pastoral farming in New Zealand: experiences from the Te Arawa Lakes, Rotorua, Australasian Journal of Environmental Management, 18:3, 139-154, DOI:

10.1080/14486563.2011.591520

${ }^{193}$ Dairy Industry Position Paper on Lake Rotorua 2009, Dairy NZ, Federated Farmers, Fonterra and Farmers in the Rotorua Catchment

${ }^{194}$ Commissioner for the Environment, Restoring the Rotorua Lakes, above $\mathrm{n} 178$

${ }^{195}$ David P. Hamilton, A Historical and Contemporary Review of Water Quality in the Rotorua Lakes, Department of Biological Sciences, University of Waikato, 2004.

196 State of the Rotorua/Te Arawa Lakes 2009-2010, above n 151

197 Ibid
} 
of these are in pasture-dominated catchments. ${ }^{198}$ Lake Ōkareka is considered reasonably clean and clear and is still able to be used for swimming. ${ }^{199}$ However, the quality of the water has been affected due to excess levels of nitrogen and phosphorus directly traced to the septic tanks and farmland surrounding it; ${ }^{200}$ three quarters of the nitrogen and $46 \%$ of the phosphorus entering Lake Rotorua can be traced to agricultural land use. ${ }^{201}$ Further sources of nitrogen and phosphorus have been identified including through erosion, stormwater, community sewerage schemes, rainfall, springs, geothermal sources, internal loads from lakebed sediment. ${ }^{202}$ The Te Arawa Lakes road to recovery has been described as a major challenge: ${ }^{203}$

This is at least a 50-year journey. The baton will have to be passed to many people over the decades. The biggest challenges are not the technical or even the financial ones, but the very human ones of keeping up the team spirit and effort over decades. It can be done but this long-term framework needs to be a substantive part of thinking, conversation and planning, now.

\section{Ownership of the Te Arawa Lakes}

\section{A Early Recognition of customary title}

When the Treaty of Waitangi was signed the Government had not attempted to exert ownership over the Te Arawa Lakes. Instead there was an acceptance that Māori owned all land not expressly appropriated by the Crown. ${ }^{204}$

Nowhere was any piece of land discovered or heard of ... which was not owned by some persons or set of persons. In this Northern Island at least it may now be

\footnotetext{
${ }^{198}$ Commissioner for the Environment, Restoring the Rotorua Lakes, above n 178, at 9.

${ }^{199}$ State of the Rotorua/Te Arawa Lakes 2009-2010, above n 151

200 Ibid.

${ }^{201}$ Commissioner for the Environment, Restoring the Rotorua Lakes, above n 178, at 14.

202 Ibid, at 13.

${ }^{203}$ Ibid, at 6.

204 Tanya June Thompson, The Rotorua Lakes: A Legal History, 1 September 1995, at 4. Published Victoria University of Wellington, available at Victoria University of Wellington Law Library.
} 
regarded as absolutely certain that with the exception of lands already purchased from the natives, there is not an acre of land available for the purposes of colonisations, but has an owner amongst the natives according to their own custom. $^{205}$

When Captain James Cook encountered the Māori for the first time in 1769 he saw "a great deal of cultivated land". The Māori plantations of kumara where described by Joseph Banks as follows: "These plantations were from 1 or 2 or 10 acres each...(and each) distinct patch was fenced in generally with reeds and placed [sic] close by another that scarce a mouse could creep through." 206 The initial implications of the cultivation of land meant that Māori did possess rights over New Zealand. The tools and methods of farming employed by the Māori were still viewed as rudimentary by the British but with a guiding hand and an incentive they were expected to improve. As one colonialist commented, the Māori: "merely needed direction, with the stimulus of a proper reward, to induce them to extend their cultivation to an indefinite extent.",207

This view of Māori exercising ownership and sovereignty over New Zealand meant a Treaty was necessary. In 1835 James Busby responded to the pressure brought on by the possibility of the French acquiring New Zealand by drafting the New Zealand Declaration of Independence. New Zealand was acknowledged in the Declaration of Independence as a free and sovereign state; 34 Māori chiefs signed this and petitioned the King of England for protection. The Treaty of Waitangi was signed on the 6th February 1840.

There are two versions of the Treaty of Waitangi - one in English and one in Māori (although almost all Māori signed the Māori language one). In Article One of the English version "sovereignty" was transferred to the Queen of England and in Article One of the Māori version "kawanatanga" was transferred to the Queen of England. The kawharu

\footnotetext{
${ }^{205}$ Sir William Martin, Chief Justice of New Zealand, Tamihana Korokai v The Solicitor General [1912], 15 GLR 95, at 103

206 J.C Beaglehole, , ed. 1955, The Journals of Captain James Cook on his journey of discovery, Vol 1, The Voyage of the Endeavor 1768 - 1771. 2 vols.2d ed. Sydney, Australia: Halstead Press

207 William Brown, 1845, New Zealand and its Aborigines. London: Smith, Elder
} 
translation views kawanatanga as meaning governance. ${ }^{208}$ In exchange for governance the chiefs were guaranteed their tino rangatiratanga and undisturbed possession of their lands and treasures, (Article Two of the Treaty of Waitangi).

Te Arawa was against the Treaty of Waitangi believing that their position over their lands and resources was secure. However in 1860, Te Arawa attended the Kohimarama conference where Te Arawa "aligned with the Crown in exchange for protection" under the Treaty of Waitangi. ${ }^{209}$

In 1880 the Fenton Agreement between the Crown and some Te Arawa chiefs provided for the Crown to establish a township in Rotorua. ${ }^{210}$ In 1881 the Thermal-Springs Districts Act was passed. This Act recognised Māori ownership of the area and provided for the governor of New Zealand to have some means to increase settlement and colonization of the area. ${ }^{211}$ Under the Thermal-Springs Districts Act, if Māori ownership of land was determined through the Native Land Court it could not be acquired by the Crown unless through negotiations between Crown and Māori. Land for these purposes included lakes, rivers and water. The Thermal-Springs Districts Act, stated that the governor can "treat and agree with the native proprietors for the use and enjoyment by the public of all mineral and other springs, lakes, rivers and waters." 212

Importantly, the Act refers to the native proprietors, which Te Arawa felt provided protection for them: ${ }^{213}$ "The Act became known to Te Arawa as their "Magna Carta" and they looked to the Act as a means of protection against alienation of their resources."214 However, despite the protection from the Thermal-Springs Districts Act, the rights of Te

\footnotetext{
${ }^{208}$ Sir Hugh Kawharu Translation of Te Tiriti o Waitangi Available: http://www.justice.govt.nz/tribunals/waitangi-tribunal/treaty-of-waitangi/the-kawharu$\underline{\text { translation }}$ Accessed : 12/12/2014

${ }^{209}$ Paul Tapsell, 'Te Arawa - 'European Impact', Te Ara - the Encyclopedia of New Zealand Available: http://www.TeAra.govt.nz/en/te-arawa/page-4 Accessed : 19/02/2014

${ }^{210}$ Te Arawa Lakes Deed of Settlement, Section 7 Historical Account

211 Tanya June Thompson, The Rotorua Lakes: A Legal History, 1 September 1995, at 9

212 Thermal-Springs Districts Act 1881 ss5 \& 6.

213 Thompson, above n 209, at 10.

214 Te Arawa Lakes Deed of Settlement, s 7
} 
Arawa were increasingly impinged upon by Crown actions discussed above, including the introduction of foreign fish species and fishing licenses.

\section{$B$ The Native Land Court and individualisation of land}

Te Arawa continued to resist land sales while developing a flax trade with markets in Auckland and Sydney. ${ }^{215}$ However, even unified resistance by Te Arawa could not effectively counter the Native Land Court and the laws it applied. According to Stuart Banner, the Native Lands Act 1865 "proved extremely successful in breaking down Māori resistance to land sales." 216 The Native Land Court replaced traditional title with Crown grants. The Court also entertained claims that enabled an individual to separate individual title from the whole or communal block. This meant that an individual could sell or alienate an individual separate plot of land. ${ }^{217}$ This process broke down Te Arawa's previous solidarity of resistance to land sales. Māori ownership and control of the total land in New Zealand went from over 60 million acres in 1800 to 7 million by $1911 .^{218}$

Te Arawa were also adversely affected throughout the 1860 s and 1870 s by Crownfacilitated loss of lands and resources - through Crown compulsory acquisition of Te Arawa property and on-sale for profit to outside developers. ${ }^{219}$ This disrupted the iwi's ability to be economically competitive. In 1886 Mount Tarawera erupted destroying the pink and white terraces, adding to the financial hardship for the iwi. So that in a climate of hardship and encroachment on their traditional authority, and Crown acquisitions Te Arawa wished to confirm their ownership to the lakes.

\footnotetext{
${ }^{215}$ Paul Tapsell, 'Te Arawa - 'European Impact', Te Ara - the Encyclopedia of New Zealand, updated 22Sep-12 URL: http://www.TeAra.govt.nz/en/te-arawa/page-4

${ }^{216}$ Banner, Stuart. "Conquest by contract: Wealth transfer and land market structure in colonial New Zealand", (2000) 34 Law and Society Review 47.

${ }^{217}$ Williams, J. A. Politics of the New Zealand Māori: Protest and Co-operation 1891 - 1909, Auckland University Press/ Oxford University Press, Auckland, 1969. Page 27.

218 Stuart Banner, "Conquest by contract: Wealth transfer and land market structure in colonial New Zealand", (2000) 34 Law and Society Review 47.

${ }^{219}$ Paul Tapsell, 'Te Arawa - Economic and social change', Te Ara - the Encyclopedia of New Zealand, updated

Available: http://www.TeAra.govt.nz/en/te-arawa/page-6

Accessed : 19/02/2014
} 


\section{The subsequent actions taken by Te Arawa for recognition of their title to the Te} Arawa Lakes 1912-1922

In 1900 members of Te Arawa tried to include part of the Te Arawa Lakes in their claims to the Native Land Court. However the presiding judge declined to include lakebeds in the title, maintaining that they were the property of all New Zealanders. ${ }^{220}$ Yet in another case the Crown was successful in having a portion of Lake Tarawera included in its application. ${ }^{221}$ So there were conflicted decisions concerning private ownership of lakebeds.

In 1908 Te Arawa made a claim to the Native Land Commission regarding the Te Arawa Lakes. In a memorandum dated 16 January 1908 Te Arawa state: "we were taught to regard the Thermal-Springs Districts Act, 1881, as the Magna Carta of our liberties, and as the declaration of the respective position of ourselves as the landowners, and as having vested interests in all that pertained to our ancestors from times past, and the Government which stood for the mana and dignity of the Crown...we are not aware that we have ever parted with our rights to any of our main lakes..."222 The Commission considered in that decision that Te Arawa had "suffered a grievous loss by the destruction of the indigenous fish cannot be denied." 223

In the pivotal case Tamihana Korokai v The Solicitor General 1912 CA the Court examined whether Tamihana Korokai could seek freehold title to the Rotorua Lakes at the Māori Land Court. ${ }^{224}$ The court held that as of 1840 onwards the Crown had not believed Māori customary land was Crown land, and that the solicitor general had not precluded the court from investigating title to the lakes merely by declaring the lakes to be Crown property. ${ }^{225}$ This decision meant that Te Arawa was free to progress their claim to the Native Land Court.

\footnotetext{
${ }^{220}$ Thompson, above $\mathrm{n} 204$, at 10.

${ }^{221}$ Ibid; Lakes Case, CL 200/25, NA Wellington.

${ }^{222}$ Te Arawa Māori Trust Board, above n 1924-1974, at 11

${ }^{223}$ Ibid.

${ }^{224}$ Tamihana Korokai v Solicitor-General (1912) 32 NZLR 321

${ }^{225}$ Ibid.
} 
The introduction of the fishing licences was one of the catalysts for Te Arawa's seeking to assert their rights to the lakes. An example of the hardship caused by the fishing licence regime is recounted in a booklet on the Te Arawa Māori Trust Board's first 50 years: ${ }^{226}$ Reverend Manihera Tumatahi returned from theological college in Gisborne and went fishing in the Ohau channel. An acclimatization society ranger asked to see Manihera's fishing licence. Manihera told the ranger that he was fishing for breakfast and would go into Rotorua and purchase a licence. This explanation was not accepted and he was issued a court summons. He was subsequently fined five pounds. The sentence was condemned by the Reverend Bennett as "a grave injustice". Manihera was fishing on his own land, into his own lake for fish liberated without his, or anyone else's consent. His explanation and actions were honest and did not warrant such a severe penalty." $227 \mathrm{Te}$ Arawa leaders held meetings to address the lakes and fishing rights issues: the iwi had not been "treated" in accordance with the legislation on the use of their fisheries and the introduction of trout as the Thermal-Springs Districts Act required. It was agreed that they would assert their neglected rights - "they could not allow future generations to grow up believing their elders had sacrificed at least part of their just inheritance."228

In 1912, Te Arawa proceeded with a claim to the Native Land Court seeking freehold title to their lakes. John Salmond, as solicitor general, advised the Attorney General to urgently legislate for all rivers, lakes and other land covered by water to be Crown land unless already held in freehold title. Salmond warned that if such legislation was not passed, freehold title to the lakes would be vested in Te Arawa. ${ }^{229}$ This advice was not heeded and the investigation over title began.

The Crown deliberately frustrated the court process by asking the Lands Department to delay the required surveying:

\footnotetext{
226 The First 50 years of the Te Arawa Māori Trust Board 1924-1974, at 10

227 Ibid.

228 Ibid.

${ }^{229}$ Salmond to the Attorney General (Wellington, 1 August 1914) Crown Law Opinion DOSLI Wellington
} 
If the Chief Surveyor at Auckland would exercise a policy of masterly delay in the matter, I could then have time to communicate with the solicitors for the Natives and suggest that the preliminary question should first be settled as to whether Native customary title extends to the bed of the large inland lakes.

The claim was furthered delayed when World War I broke out in 1914 and Te Arawa agreed to halt the claim in contribution to the war effort. ${ }^{230}$ The claim was bought up again in 1917 and the court decided to hear Te Arawa's evidence, after which "the Crown deliberately frustrated Te Arawa's preparation of their case by obstructing access to public maps for approximately four months." 231 The obstruction of the judicial process by the Crown not surprisingly caused financial strain to Te Arawa. ${ }^{232}$ The case was then further delayed by Te Arawa's solicitor being unavailable for court dates, with the Native Land Court eventually able to begin the investigation into Te Arawa's claim to Lakes Rotorua and Rotoiti in October 1918.

At the hearing Te Arawa contended that the Treaty of Waitangi confirmed their title, that ownership did not pass to the Crown under the Treaty of Waitangi, and that ownership had not passed to the Crown since the Treaty of Waitangi. ${ }^{233}$ Te Arawa further argued that the Thermal - Springs Districts Act 1881 confirmed their title to the lakes, as they were the "Native proprietors." ${ }^{234}$ After hearing arguments, the Native Land Court adjourned. However the presiding judge died during the adjournment. The case was not reconvened in 1919 as there was no replacement judge. ${ }^{235}$ When the case was about to be resumed the Crown (concerned that the freehold orders would be issued) asked Te Arawa to negotiate. ${ }^{236}$

Following negotiations Te Arawa and the Crown agreed to a settlement on 24 March 1922 covering Lakes Rotoehu, Rotomā, Rotoiti, Rotorua, Ōkataina, Ōkareka,

\footnotetext{
${ }^{230}$ Te Arawa Lakes Deed of Settlement, s7

${ }^{231}$ Ibid.

${ }^{232}$ Thompson, above n 204, at 17; Lakes Case, CL 200/25, NA Wellington.

${ }^{233}$ Te Arawa Lakes Deed of Settlement, Section 7 Historical Account

${ }^{234}$ Thermal - Springs Act 1881 ss7; Thompson, above n 204, at 20; Lakes Case, CL 200/25, NA Wellington.

${ }^{235}$ Te Arawa Lakes Deed of Settlement, s 7.

${ }^{236}$ Ibid.
} 
Rerewhakaaitu, Tarawera, Rotomahana, Tikitapu (the Blue Lake), Ngāhewa, Tutaeinanga, Ngāpouri, and Ōkaro, on the following terms: ${ }^{237}$

"1....the Crown admits the rights of the Arawas to their ancient fishing rights and the burial reserves in all the Lakes, and the Arawas admit that the fee simple of the Lakes is vested in the Crown.

2. With respect to the lake known as the "Green Lake"- Rotokakahi, a special Board be Appointed for the control of the surroundings of that Lake, the island to be one of the burial places.

3. 40 instead of 20 licences to fish for trout in the Lakes at a nominal fee.

4. With respect to the indigenous fish...no trading in such fish shall at any time be permitted.

5. The Civil List Act be amended to add $£ 4,000$ to the present $£ 7,000$ for native purposes, and to appropriate $£ 2,000$ of the $£ 7,000$ to the Arawas; and the $£ 6,000$ so provided to be paid annually to a Board to be established for the purposes of benefit to the Arawa tribe...With regard to the expenditure already incurred by the Arawas in litigation in the Lakes claims...this has been considerable... a payment limited to $£ 2,000$ is proposed...". There was no provision in the agreement for the annuity to be reviewed.

Te Arawa was plainly on an unequal footing in relation to this negotiation as the Crown could dictate the terms of any inquiry and abuse its position by delaying a Native Land Court investigation. ${ }^{238}$ Further, there was no deed signed by Te Arawa members, nor any other record of authorization of the settlement from the majority of the Te Arawa iwi. ${ }^{239}$ The validity of the 1922 settlement is clearly open to question. ${ }^{240}$

\section{Waitangi Tribunal Claim}

The Treaty of Waitangi Act 1975 was amended in 1985, providing for claims to the Waitangi Tribunal to be made for Crown actions from 1840 onwards. The Arawa Māori Trust Board registered a claim in relation to the Te Arawa Lakes (Wai 240) in April 1987. ${ }^{241}$ The Board and the Crown held negotiations between 1999 and 2001. The first Crown settlement offer was rejected by the Board, but both parties agreed that the future

\footnotetext{
237 Ibid.

238 Thompson, above n 204, at 10 .

${ }^{239}$ Ibid, at 11

${ }^{240}$ Ibid at 12

241 Te Arawa Lakes Deed of Settlement, s 7
} 
settlement would cover Te Arawa's historical claims and any remaining annuity issues from the 1922 settlement. ${ }^{242}$

In December 2003 the Crown made a second offer, which was accepted by the Board. On 26 November 2004, over 93\% of the members of Te Arawa who took part voted to accept the Deed of Settlement. ${ }^{243}$ The settlement provided for a co-management structure to be made permanent for the governance of the Te Arawa Lakes meaning Te Arawa could once again be caretakers of the lakes but in a different capacity and in conjunction with Crown entities.

\section{Summary}

Te Arawa has a traditional relationship as the owners and spiritual connection to the $\mathrm{Te}$ Arawa Lakes. Through colonisation and government policy imposed by the Native Land Court Māori throughout New Zealand were alienated from their lands and resources. Te Arawa rights to their lakes were overtaken by the Crown and severe environment damage was done. Te Arawa sought the acknowledgement and return of their ownership rights for over 100 years pursuing all the legal avenues available. Te Arawa's claim to the lakes was extinguished under the Te Arawa Lakes Deed of Settlement Act 2006. The agreement reached is addressed in the next chapter.

\footnotetext{
242 Ibid

243 Ibid
} 


\section{Chapter Three: Te Arawa Lakes Settlement Act 2006}

\section{Introduction}

This chapter aims to provide a detailed description of the formal, written co-management structure currently in place for managing the Te Arawa Lakes. ${ }^{244}$ This involves understanding the settlement reached between the Crown and Te Arawa under the Te Arawa Lakes Settlement Act 2006 (the Act) and related documentation including the follow up Memorandum of Understanding 2007.

The Act records the agreement reached through negotiations between the Te Arawa Māori Trust Board and the Crown. The purpose of the Act is to record the acknowledgements and apology given by the Crown to Te Arawa in the deed of settlement dated 18 December 2004 and to give effect to the provisions of the deed of settlement. ${ }^{245}$ The Act has four parts: Part 1 records the Crown's acknowledgements and apologies; Part 2 provides for cultural redress to Te Arawa in the form of the return of freehold title to 13 of the Te Arawa Lakes lakebeds; and Part 3 provides for 'other cultural redress' - the statutory creation of the Rotorua Te Arawa Lakes Strategy Group (The RTALSG); Part 4 deals with the incorporation of parts of the deed of settlement into the Act, the dissolution of the Arawa Māori Trust Board and the transition to the Trustees of the Te Arawa Lakes Trust. Parts $1-3$ are examined below. Then the individual organisations involved in the co-management are looked at in further detail. This includes consideration of the roles and responsibilities of each as provided for under the Memorandum of Understanding 2007 and the 2004 Agreement.

\footnotetext{
244 Section 11 Te Arawa Lakes means (a) means Lakes Ngāhewa, Ngāpouri (also known as Ōpouri), Ōkareka, Ōkaro (also known as Ngākaro), Ōkataina, Rerewhakaaitu, Rotoehu, Rotoiti, Rotomā, Rotomahana, Rotorua, Tarawera, Tikitapu, and Tutaeinanga; and (b) includes the water, fisheries, and aquatic life in those lakes; but (c) does not include the islands in those lakes or the land abutting or surrounding those lakes

245 Te Arawa Lakes Settlement Act 2006, s 3
} 


\section{Te Arawa Lakes Settlement Act, 2006: Part 1: Acknowledgement and apology}

\section{A Acknowledgement}

Section 7 of the Act records the acknowledgements made by the Crown for its actions pertaining to the Te Arawa Lakes and the effects on the Te Arawa people. ${ }^{246}$ It commences by recognising that the lakes were taonga to Te Arawa and of spiritual, cultural, economic, and traditional importance to the iwi. ${ }^{247}$ The acknowledgement then covers a host of Crown actions that were detrimental to the Te Arawa Lakes and the Te Arawa people including:

(1) The introduction of exotic fish species which "significantly depleted the indigenous species upon which Te Arawa depended for food, hospitality, trade, and koha;",248

(2) Failure to take action after Te Arawa petitioned the Crown for several years concerning the depletion of the indigenous species and access to the new species; ${ }^{249}$

(3) Prosecuting some members of the Te Arawa iwi for fishing without a licence in the lakes during this time; ${ }^{250}$

\footnotetext{
${ }^{246}$ Section 12 of the Act defines what is meant by Te Arawa as follows: every individual who is:

(i) descended from a Te Arawa ancestor:

(ii) a member of an iwi, hapū, group, family, or whānau referred to in paragraph (c); and(c)includes(i)the iwi and hapū of Te Arawa listed in Schedule 2; and (ii)any iwi, hapū, group, family, or whānau composed of individuals referred to in paragraph (b).)

In this section and section 13, Te Arawa ancestor means an individual who, at any time after 6 February 1840, exercised customary rights in relation to the Te Arawa lakes by reason of being descended from a recognised ancestor of an iwi or hapū of Te Arawa. In this section, customary rights means rights according to Te Arawa tikanga (customary values and practices of Te Arawa), including (a) rights of occupation and use; and (b) rights in relation to the use of natural or physical resources.

${ }^{247}$ Te Arawa Lakes Settlement Act 2006, s 7 (1)

${ }^{248}$ Ibid, at s 7 (2) (a)

${ }^{249}$ Ibid, at s 7 (2) (b)

${ }^{250} \mathrm{Ibid}$, at s 7 (2) (c)
} 
(4) Failure to legislate for a sufficient number of fishing licences for Te Arawa in 1908, in breach of te Tiriti o Waitangi (the Treaty of Waitangi) and its principles, ${ }^{251}$ and

(5) Failure to review the annuity paid to Te Arawa as part of the 1922 agreement regarding the lakes when it materially lost value as a result of inflation, in breach of te Tiriti o Waitangi (the Treaty of Waitangi) and its principles. ${ }^{252}$

The Crown further acknowledges that its deliberate delays in providing survey plans and public maps to Te Arawa for the Native Land Court hearings caused a sense of grievance within Te Arawa that is still held today. ${ }^{253}$ The Crown acknowledges that its past actions in relation to the Te Arawa Lakes have had a negative impact on Te Arawa's tino rangatiratanga over the lakes and their use of the resources of the lakes. In addition under Crown authority environmental damage had taken place to the lakes and this has caused a sense of grievance within Te Arawa. ${ }^{254}$

In contrast to the Crown's behavior, it is acknowledged that Te Arawa honored their obligations under the Treaty of Waitangi. Particular recognition is accorded to $\mathrm{Te}$ Arawa's service in the First World War and the gifting of portions of the annuity for 'national good in the 1930s and 1940s. ${ }^{255}$ It is further acknowledged that Te Arawa had co-operated with the Crown to form a relationship but that the benefits that Te Arawa expected to flow from this relationship were not always realized. ${ }^{256}$

The Crown acknowledges the significant contribution that the Te Arawa Lakes have made to tourism and the wealth of New Zealand and of the Rotorua district in particular. ${ }^{257}$ The Crown also recognises the longstanding grievances of Te Arawa in relation to Crown acts and omissions concerning the Te Arawa Lakes, grievances expressed through petitions to the Government and the Stout-Ngata Commission. Finally,

\footnotetext{
${ }^{251}$ Ibid, at s 7 (2) (d)

252 Ibid, at s 7 (4)

${ }^{253}$ Ibid, at s 7 (3)

${ }^{254}$ Ibid, at $\mathrm{s} 7$ (5)

255 Ibid

256 Ibid

${ }^{257}$ Ibid, at s 7 (6)
} 
the Crown acknowledges that it has failed to deal with those grievances in an appropriate way and that recognition of Te Arawa's grievances is long overdue. ${ }^{258}$

\section{B Apology}

The Crown's apology to Te Arawa is an important component of the settlement. It follows the acceptance of wrongs done to Te Arawa, clearly identifying what the Crown is apologising for. The apology looks towards making new relationships and moving forward to begin the process of healing. Sections 8 and 9 record the Crown's apology in English and Māori respectively. The English version reads as follows:

The Crown makes this apology to Te Arawa, to their ancestors, to their descendants and to the people and hapū of Te Arawa:

The Crown profoundly regrets and unreservedly apologises to Te Arawa for the breaches of te Tiriti o Waitangi (the Treaty of Waitangi) and its principles acknowledged above. The Crown profoundly regrets that past Crown actions in relation to the lakes have had a negative impact on Te Arawa's rangatiratanga over the lakes and their use of lake resources, and have caused significant grievance within Te Arawa. Accordingly, with this apology, the Crown seeks to atone for these wrongs and begin the process of healing. The Crown looks forward to building a relationship of mutual trust and cooperation with Te Arawa in respect of the lakes. ${ }^{259}$

\section{Full and final settlement}

Section 15 of the Act provides that the settlement of the Te Arawa Lakes remaining annuity issues affected under the deed of settlement is a full and final settlement. From the settlement date the Crown is released and discharged from all obligations and liabilities in respect of those claims. ${ }^{260}$

\footnotetext{
${ }^{258}$ Ibid, at s 7 (7)

${ }^{259}$ Ibid, at s 9

${ }^{260}$ Ibid, at s 15
} 


\section{Te Arawa Lakes Settlement Act, 2006 Part 2: Cultural redress}

\section{A Vesting of lakebeds in Te Arawa}

Part 2 of the Act provides for the vesting of the fee simple title to 13 of the Te Arawa Lakes lakebeds to the trustees of the Te Arawa Lakes Trust. The lakebeds were previously vested in the Crown under the Māori Purposes Act 1922. Lake Ōkaro remains under the ownership of the Bay of Plenty Regional Council, but the Act contains a recommendation that the Ōkaro Lakebed be transferred back to Te Arawa, a move the council is supporting. ${ }^{261}$ The Act provides for the revocation of Eastern Region Fish and Game New Zealand's management of the Lake Ngapouri Wildlife Management Reserve and the Lake Tutaeinanga Wildlife Management Reserve. ${ }^{262}$

Section 23 vests the 'fee simple estate in each Te Arawa lakebed in the Trustees of the Te Arawa Lakes Trust." 263 The Te Arawa lakebed is defined as "the stratum comprising the land defined by the legal description for that lakebed, as set out schedule 1 including the subsoil beneath that land and plants attached to that land."264 The Crown retains the ownership of the "Crown stratum" which is defined as "the space occupied by water and the space occupied by air above each Te Arawa lakebed."265

The definition of lakebed under section 11 is "the stratum comprising the land defined by the legal description for that lakebed."266 The definition contains the following exclusions: the Crown stratum; any submerged land not owned by the Crown; any land that is not submerged land, whether or not owned by the Crown, including any island

\footnotetext{
${ }^{261}$ Councilors voted unanimously to support the transfer of Lake Ōkaro's lakebed to Te Arawa Lakes Trust with a guarantee of continued public access. They also resolved to ask the Crown for financial assistance and for recommendations on a process to expedite the lakebed transfer. One related issue to be dealt with remained the question of who would manage the lake's surrounding reserve, and whether it would be managed by one of the parties, or through a co-management process. Available:http://www.rotorualakes.co.nz/latest_news/id/185/District\%20Council\%20supports\%20Lake\%2 $\underline{0}$

Accessed: $12 / 03 / 2014$

262 Te Arawa Settlement Act, above n 247, ss 20, 21

263 Ibid, at s23

${ }^{264}$ Ibid, at s11

265 Ibid

266 Ibid
} 
in the relevant lake; any existing structure situated in or on that lakebed (or in the Crown stratum); and any aquatic life in the relevant lake and the Ohau Channel between Lakes Rotorua and Rotoiti. However the plant life attached to the lakebed is included in the lakebed title. ${ }^{267}$

The separation of the lakebed from the water, and the water from the space above it, means that both Te Arawa Lakes Trust and the Crown are owners but it imposes a legally constructed separation on the whole of the lake.

\section{B Limitations and encumbrances to lakebed title}

\section{$i$ Alienation of lakebed}

The vesting of freehold title to the lakebeds is subject to a number of encumbrances and limitations: The Trustees of the Te Arawa Lakes Trust must not dispose of or alienate the freehold estate, or grant or create a mortgage or other charge over all or part of a $\mathrm{Te}$ Arawa lakebed. ${ }^{268}$ However the Trustees may grant a leasehold estate in a Te Arawa lakebed for a maximum term of 35 years, including renewals. This term can be extended, provided both the Crown and Te Arawa agree. ${ }^{269}$ The Trustees may grant a licence, easement, or profit à prendre over all or part of a Te Arawa lakebed for any term. ${ }^{270}$

\section{ii Right to water and aquatic life}

The Act is very clear that no right to water is being granted to Te Arawa. Section 25 provides:

To avoid doubt, the vesting in the Trustees of the Te Arawa Lakes Trust of the fee simple estate in the Te Arawa lakebeds by section 23 does not confer on the Trustees any rights or obligations in relation to-

(a) the water in the Te Arawa Lakes; or

\footnotetext{
267 Ibid, at s25

${ }^{268}$ Ibid, at s24 (1) (a) (b )

${ }^{269}$ Ibid, at s24 (3)

${ }^{270} \mathrm{Ibid}$, at s24 (4)
} 
(b) the aquatic life in the Te Arawa Lakes, except in relation to the plants attached to the lakebeds. ${ }^{271}$

The Act is silent as to the ownership of the water itself. ${ }^{272}$

\section{iii Liability for weeds and contamination}

Te Arawa is not liable for the weeds attached to the lakebed or responsible for their control or removal. ${ }^{273}$ The fee simple lakebed title does not make Te Arawa responsible for the contamination of a Te Arawa lakebed, unless the contamination is caused by an intentional or reckless act or omission, or negligent act, of the Trustees. ${ }^{274}$

iv Minerals and precious metals

The Act provides that the Crown retains ownership of petroleum, gold, silver and uranium and retains the right to a reservation in favor of the Crown for every mineral existing in its natural condition in the lakebed under sections 10 and 11 of the Crown Minerals Act 1991. ${ }^{275}$ The vesting of the fee simple estate in a Te Arawa lakebed by section 23 does not limit the rights and obligations of the Crown or a local authority in respect of geothermal resources under the Resource Management Act 1991 or any other relevant enactment or rule of law. ${ }^{276}$

\section{$v$ Public access}

Te Arawa's ownership of the lakebeds is also subject to the common law right of navigation. This right continues to apply over each Te Arawa lakebed and the Crown stratum above each lakebed without the consent of the Trustees and without charge by the

\footnotetext{
${ }^{271}$ Ibid, at s25 (a) (b)

272 Ibid, at s25

${ }^{273}$ Ibid, at s26

274 Ibid, at s27

275 Ibid, at s28 (4) (a)

276 Ibid, at s28 (4)
} 
Trustees. ${ }^{277}$ The public also has the right to use the lakebed for recreational purposes (including recreational swimming, boating, water-skiing, and fishing). These activities too can take place without the consent or charge of the Trustees. ${ }^{278}$ In addition any existing structures can remain and be used without permission or charge by Te Arawa. ${ }^{279}$ Any existing types of commercial activates can also continue. ${ }^{280}$ However any new structures or modification of existing structures need the consent of both Te Arawa and the Crown. ${ }^{281}$

\section{Te Arawa Lakes Settlement Act, 2006, Part 3: Other cultural redress - co-management of the Te Arawa Lakes}

\section{A Background to the Rotorua Te Arawa Lakes Strategy Group}

In 1998, prior to the settlement, the Chairman of the Te Arawa Māori Trust Board, the Chairman of Bay of Plenty Regional Council (BOPRC) and the Mayor of Rotorua District Council (RDC) formed a Lakes Strategy Working Group (LSWG). These parties were all involved in the management of the lakes in some shape or form but were not coordinated in their approach. ${ }^{282}$ The RDC and BOPRC have statutory obligations in relation to the management of the lakes; with the BOPRC responsible for "promoting the sustainable management of natural and physical resources for the present and future generations." ${ }^{283}$ BOPRC is also in charge of soil conservation and river control in the lakes catchments and must check the effect of human activities on the environment including imposing regulations to limit the use of resources when necessary. ${ }^{284} \mathrm{In}$ addition BOPRC consults and co-ordinates with the Bay of Plenty community to form

\footnotetext{
${ }^{277}$ Ibid, at s31

${ }^{278}$ Ibid, at s32

${ }^{279}$ Ibid, at s33

${ }^{280}$ Ibid

${ }^{281}$ Ibid

${ }^{282}$ Vision and Strategy for the Lakes of the Rotorua District 2014

Available: http://www.rotorualakes.co.nz/vdb/document/533

Accessed : 22/02/2015

${ }^{283}$ Vaughan Payne, Rotorua Lakes Strategy co-management project team. "Rotorua Lakes strategy comanagement options: report" 2001.

${ }^{284}$ Resource Management Act 1991, s 31
} 
policies. The RDC has statutory responsibilities pertaining to the lakes, including responsibility for disposal of waste water and sewage and domestic water supply. ${ }^{285}$ The BOPRC and the RDC also have direct statutory responsibilities to Te Arawa under the Resource Management Act 1991 (RMA); under section 5 they are required to ensure that Māori interests and values are incorporated into management decisions. ${ }^{286}$

The LSWG aimed to create cohesion and collaboration between these different parties by creating a common strategy document that they would work to implement together. ${ }^{287}$ They planned a team approach to mitigate against problems caused through a lack of communication and unity between the parties: "The purpose was to provide an agreed vision for the lakes of the Rotorua district, unite efforts and focus resources to achieve that vision." 288

In August 2000, the LSWG adopted the original strategy for the lakes of the Rotorua district (the 2000 Strategy). ${ }^{289}$ The strategy outlined the value the lakes hold for the people of Rotorua and New Zealand, stating that the lakes and catchments must be preserved and protected for future generations, whilst recognising the traditional relationship Te Arawa has with their ancestral lakes. A collaborative and inclusive approach was taken in the preparation of the strategy - local individuals and organisations throughout the Rotorua District were consulted and asked for their views on what they wanted to achieve for the lakes including specific goals. The result was a list of 14 goals:

(1) address the causes of lake water pollution

(2) deal with pollution from septic tanks

(3) determine the extent of pollution from storm water runoff

(4) define and refine lake water quality standards

(5) examine the status and future of the catchment bank protection scheme

(6) address plant and animal pest problems

\footnotetext{
285 Ibid

${ }^{286}$ Resource Management Act, above n 284, s5

${ }^{287}$ Vision and Strategy 2014, above n 281

${ }^{288}$ Ibid

${ }^{289}$ Strategy for the Lakes of the Rotorua District (2000)

Available: http://www.rotorualakes.co.nz/vdb/document/219

Accessed : 02/02/2014
} 
(7) determine present and future reserve areas

(8) establish an urban development policy

(9) establish a rural development policy

(10) develop a recreation strategy

(11) monitor and report on recreation activities

(12) define esplanade reserve areas to ensure public access to each lake

(13) establish in partnership with Te Arawa a co-management framework that achieves the best integrated management

(14) establish meaningful and binding working relationships with the iwi/hapu and their ancestral lakes.

The 2000 Strategy made a situational statement that conflicts of understanding exist among the agencies administering the lakes. Conflicts exist between Māori and European notions of "ownership" and the different understandings are not accommodated in the existing management approaches. The strategy then presented three options: (a): continue current practices in accordance with legislation; b) develop and implement lakes management policy in consultation with the individual hapu of Te Arawa; (c): establish a management team structure including the direct involvement of Te Arawa as part of the team to create and implement lakes management policy. Option c was selected.

The strategy stated the parties' commitment to co-ordinate efforts for a unified vision for the lakes of the Rotorua district, focusing on channelling community energy and resources into actions that achieve the vision. ${ }^{290}$ The document outlined that to achieve that unified vision it would be important to identify costs and rewards of actions, complete tasks, hold regular reviews to ensure accountability and effectiveness, and report on progress to the public. ${ }^{291}$

The LSWG was created through three organisations joining together to form a group that they hoped could provide the overarching governance needed to restore the lakes. The LSWG then commissioned a report to provide advice on co-management options. Various

\footnotetext{
${ }^{290}$ Ibid at 1.

${ }^{291}$ Ibid at 1-63.
} 
options were canvassed by the Rotorua Lakes co-management project team. ${ }^{292}$ The report outlined outcomes the LSWG hoped to achieve and how the management should function to enable them to meet those outcomes. The three parties outlined their desired individual outcomes as follows: ${ }^{293}$

(a) Te Arawa sought partnership in perpetuity with the Crown and its agencies, legal recognition of the kaitiaki and rangatira role of Te Arawa over the lakes, tributaries, outlets and associated taonga. The exercise of kaitiaki and rangatira was to be achieved by direct involvement (as of right) in a new governance structure with final decision-making powers over final approval of policies and decisions on resource consent applications of a certain threshold. Te Arawa also sought direct involvement in management activities such as monitoring, regeneration, rahui and public access. Te Arawa's environmental goals were protection and enhancement of the mauri of the lakes and the ability to use and enjoy their ancestral taonga, including living on lands owned by Te Arawa.

(b) The RDC sought establishment of a lake kaitiaki to advocate for the well being of each lake, a direct and continuing working relationship with BOPRC and Te Arawa regarding lake policies and plans and integrated management between the three parties. The RDC also specified wanting clear guidance by Te Arawa on those matters relating to the lakes which RDC must address when considering the principles of the Treaty of Waitangi. The environmental outcomes sought were that: lake water quality be maintained or improved, the public have a right of access; taonga be identified so RDC could fulfil its obligations under the RMA to protect the relationship between Te Arawa and their ancestral lands.

(c) BOPRC sought that the parties work together in close liaison as equal partners, and there be integrated management by BOPRC, RDC and Te Arawa. Environmental outcomes sought were: integrated land and water management, sustainable land use in the lakes' water catchments, and maintained and improved lake water quality.

\footnotetext{
${ }^{292}$ Rotorua Lakes Strategy co-management project team. Rotorua Lakes strategy co-management options: report/prepared for the Rototrua Lakes Strategy Governance Group, facilitated by Vaughan Payne 2001, at 1. Available on Request Bay of Plenty Reginal Council Library

${ }^{293}$ Ibid, at 10-43.
} 
The report identified the following management functions as necessary to give effect to the vision of the lakes' strategy: ${ }^{294}$

(1) The provision of leadership to the Board, RDC and BOPRC and the community in relation to the implementation of the vision;

(2) The identification of significant existing and emerging issues affecting the Rotorua Lakes;

(3) The preparation, approval, monitoring, evaluation and review of agreements, policies and strategies to achieve integrated outcomes for the Rotorua Lakes;

(4) The identification, monitoring and evaluation of necessary actions by the Board, RDC and BOPRC and other relevant organisations;

(5) The receiving of reports on activities being undertaken by the Board, RDC, BOPRC and any other relevant organizations;

(6) Involvement in the preparation of statutory places in relation to significant issues. Such plans include but are not limited to iwi and hapu management plans, district and regional plans, reserve management plans, and annual plans; and

(7) Involvement in applications for activities in relation to significant issues not addressed by existing policies of the co-management body. Activities include resource consents, designations, heritage orders, water conservation orders, restricting access to the lakes and transferring or delegating of statutory authority.

In order to achieve the above goals and management functions the report recommended settlement of grievances under the Treaty of Waitangi and incorporation of the LSWG as it provides for a "long term working relationship as agreed by the three parties." 295 The report proposed an interim measure of a joint management committee under the Local Government Act. Following the recommendations made by the report the LWSG then established itself as a joint committee - the Rotorua Lakes Strategy Joint Committee in 2003 under Clause 30 of Schedule 7 of the Local Government Act 2002. The joint committee structure was

\footnotetext{
${ }^{294}$ Ibid, at 20-43

${ }^{295}$ Payne, Co-management options report, above n 292 at part 9.
} 
permanently recognised and authorised through formal statutory creation under Part 3 of the Act as the statutory entity to manage the Te Arawa Lakes - the Rotorua Te Arawa Lakes Strategy Group.

\section{B Rotorua Te Arawa Lakes Strategy Group}

Under Section 48 of the Act provides that the Rotorua District Council and the Bay of Plenty Regional Council must establish the 'Rotorua Te Arawa Lakes Strategy Group' (RTALSG) by the settlement date. ${ }^{296}$ The RTALSG is responsible for the management of Lakes Ōkareka, Ōkaro, Ōkataina, Rerewhakaaitu, Rotoehu, Rotoiti, Rotokakahi, Rotomā, Rotomahana, Rotorua, Tarawera, and Tikitapu. ${ }^{297}$ The members of the RTALSG are to be appointed by "the organisations." 298

The "organisations" are the Rotorua District Council, the Bay of Plenty Regional Council, and the Trustees of the Te Arawa Lakes Trust ${ }^{299}$ Although not charged with the establishment of the RTALSG Te Arawa is one of the organisations with the power of appointment of members and therefore its membership in the RTALSG is secured as a right. The RTALSG is still a 'joint committee' within the meaning of clause 30 (1) (b) of Schedule 7 of the Local Government Act 2002. However the Act provides that the RTALSG will be a permanent committee and cannot be discharged following a local authority triennial general election. The RTALSG can only be discharged if each organisation agrees. ${ }^{300}$ The permanence of the committee is in line with the recommendations from the Johannesburg summit identified in chapter one that a long term perspective is needed for sustainable development.

The purpose of the RTALSG is to contribute to the promotion of the sustainable management of the Rotorua Lakes and their catchments, for the use and enjoyment of present and future generations, while recognising and providing for the traditional

\footnotetext{
${ }^{296}$ Settlement date means the date that is 20 business days after the date on which this Act comes into force section 11

${ }^{297}$ Te Arawa Lakes Act, above n 247, s 47

298 Ibid, at s48

299 Ibid, at s 47

${ }^{300}$ Ibid, at s 48
} 
relationship of Te Arawa with their ancestral lakes. ${ }^{301}$ Each of the organisations, and the RTALSG jointly, must comply with the terms of the Rotorua Lakes Strategy Group agreement. $^{302}$

\section{Rotorua Te Arawa Lakes Strategy Group Agreement}

The Rotorua Lakes Strategy Group Agreement (the Agreement) was entered into on 8 October 2004 between the Arawa Māori Trust Board on behalf of Te Arawa, the RDC and the BOPRC. The Agreement discharges the Rotorua Lakes Strategy Joint Committee contemporaneously with the establishment of the RTALSG. The Agreement outlines the RTALSG's membership makeup, meetings, its purpose and initial functions. The Agreement provides for the RTALSG's management of the "Rotorua Lakes" - meaning Lakes Rotorua, Rotoiti, Rotoehu, Rotomā \& Okataina, Tikitapu, Okareka, Tarawera, Rotomahana, Rerewhakaaitu, Ōkaro and Rotokakahi. ${ }^{303}$ The RTALSG is also responsible for Lake Ōkaro which is still vested in the RDC.

\section{i Membership}

The Agreement provides there will be six members in the RTALSG: two representatives from TALT, two representatives from the RDC, two representatives from the BOPRC. ${ }^{304}$ The RTALSG's chairman will be rotated annually. ${ }^{305}$

The two Te Arawa members must be the chairperson of the Te Arawa Governance Entity and a senior executive of that Entity. ${ }^{306}$ The BOPRC members must be the Chairperson of

\footnotetext{
301 Ibid, at s 49

302 Ibid, at s 50

${ }^{303}$ Te Arawa Lakes Deed of Settlement 2004, Relationship Schedule, Part 1, Rotorua Lakes Strategy Group Agreement, clause 1.1

${ }^{304}$ Rotorua Te Arawa Lakes Strategy Group - Terms of Reference, at 1.1.3

Available: http://www.boprc.govt.nz/media/306978/rotorua-te-arawa-lakes-strategy-group-terms-ofreference-2013-2016.pdf

Accessed : 27/02/2014

${ }^{305}$ Ibid, at 1.1 .4

${ }^{306}$ Rotorua Te Arawa Lakes Strategy Group, Terms of Reference, Above n 304, clause 2.
} 
the Council and one other councillor. The RDC members must be the current Mayor and one other appointed by the RDC.

\section{ii Quorum}

The ordinary quorum for a meeting of the RTALSG will be one member from each of the Organisations. ${ }^{307}$ The special quorum for a meeting of the RTALSG is four members of the RTALSG. ${ }^{308}$ In the event that the ordinary quorum is not satisfied at three consecutive meetings of the RTALSG, then the members in attendance may declare the third meeting inquorate according to the Standing Orders and the special quorum will then be substituted.

\section{iii Initial functions}

The RTALSG will initially have the following functions: ${ }^{309}$

(1) the provision of leadership to the organisations and the community in relation to implementation of the vision; ${ }^{310}$

(2) the identification of significant existing and emerging issues affecting the Rotorua Lakes; ${ }^{311}$

(3) the preparation, approval, monitoring, evaluation and review of agreements, policies and strategies to achieve integrated Outcomes for the Rotorua Lakes; ${ }^{312}$

(4) the identification, monitoring and evaluation of necessary actions by the organisations and other relevant organisations; ${ }^{313}$

\footnotetext{
${ }^{307}$ Ibid, clause 3

${ }^{308}$ Ibid, clause 3.2

${ }^{309}$ Rotorua Te Arawa Lakes Strategy Group, Terms of Reference, above n 304, 1.1.6

${ }^{310} \mathrm{Ibid}$, at 4.1

${ }^{311} \mathrm{Ibid}$, at 4.2

312 Ibid, at 4.3

${ }^{313}$ Ibid, at 4.4
} 
5) the receiving of reports on activities being undertaken by the organisations and other relevant organisations; ${ }^{314}$

(6) involvement during the preparation of statutory plans in relation to significant issues. Such plans include but are not limited to iwi and hapü management plans, district and regional plans, reserve management plans, and annual plans; ${ }^{315}$

(7) involvement in applications for activities in relation to significant issues not addressed by existing policies of the co-management partners. Such activities include but are not limited to resource consents, designations, heritage orders, water conservation orders, restricting access to the lakes (during special events or in particular circumstances), and transferring and/or delegating of statutory authority.

\section{iv Amendments}

The Agreement may be amended with the consent of each of the organisations of the RTALSG. An agreement to amend this agreement will have no effect until recorded in writing and signed by each of the organisations of the RTALSG. ${ }^{316}$

Under the terms of reference the strategy group seems to be overseeing and involved in the work done by the organisations, rather than the strategy group doing the work themselves

\section{About the RTALSG "organisations"}

These organisations are individual entities that have been established for different purposes. They each however have responsibilities pertaining to the Te Arawa Lakes. To understand how the co-management arrangement operates it is important to understand the organisations involved.

\footnotetext{
314 Ibid, at 4.5

315 Ibid, at 4.6

${ }^{316}$ Rotorua Te Arawa Lakes Strategy Group, Terms of Reference Above n 304, Clause 8
} 


\section{A Te Arawa Lakes Trust}

The Te Arawa Lakes Trust (previously the Te Arawa Māori Trust Board established by the 1922 settlement legislation) is the governance entity created to receive and manage the settlement redress received by Te Arawa from the Crown. The benefits of the settlement will be available to all registered members of Te Arawa, wherever they live. ${ }^{317}$ The current Chairman of the Te Arawa Lakes Trust is Sir Toby Curtis.

The Trust has a central administration arm, which provides management support to the Trust. It has a chief operating officer, currently Roku Mihinui, and 6 other staff members. ${ }^{318}$ The Trust also has an education unit with 3 staff who provide training and education to a maximum of thirty-five rangatahi under contract to the Tertiary Education Commission. ${ }^{319}$ The Trust has direct accountability to the beneficiaries, balancing financial aims with social responsibility. The Trust's mission statement is "Utilisation and management of the assets and resources to provide cultural, social, environmental and economic sustainability for Te Arawa." ${ }^{320}$ The Trust states their vision as follows:

Kia tu motuhake a Te Arawa i roto i te whakakotahitanga ma te urupu me te whakatutuki o o tatau tikanga

Te Arawa to be unified and independent based on a strong understanding and practice of their tikanga ${ }^{321}$

\section{B Rotorua District Council}

The RDC is a territorial authority, a form of local government, with a wide range of responsibilities. District Councils are empowered through the Local Government Act

\footnotetext{
${ }^{317}$ Te Arawa Iwi website Available: http://www.tearawa.iwi.nz/about-trust Accessed : 22/02/2015

${ }^{318}$ Ibid.

${ }^{319}$ Ibid.

${ }^{320}$ Ibid

${ }^{321}$ Ibid.
} 
2002 with wide ability to operate provided they are doing so within the purpose of local government. $^{322}$

The statutory purpose of local government is:

to enable democratic local decision-making and action by, and on behalf of, communities; and to meet the current and future needs of communities for goodquality local infrastructure, local public services and performance of regulatory functions in a way that is most cost-effective for households and businesses. ${ }^{323}$

District Councils are intended to be representative of their communities' needs and wishes. They are mandated to participate with the local community and involve them in the decision making process. ${ }^{324}$ The current mayor of the RDC is the Right Hon Steve Chadwick. The responsibilities of a district council include: community infrastructure such as parks, museums, playgrounds and recreation centres, controlling the effects of land use through planning and resource consents, environmental safety and health, controlling the effects of land, and the effects of activities on the surface of lakes and rivers. $^{325}$

\section{Bay of Plenty Regional Council}

The BOPRC has 13 councillors, of whom 10 are elected from general rolls and 3 from Māori constituency areas. ${ }^{326}$ The councillors are elected by registered voters in the Bay of Plenty. The BOPRC council employs around 275 staff. It is managed by a chief executive Mary Anne McCloud and is divided into six teams; environmental management, natural hazards, strategy, natural resource operations, people and performance, and finance. ${ }^{327}$

\footnotetext{
322 Local Government Act 2002, Section 12 (2)

${ }^{323}$ Ibid, at s 10(1)

${ }^{324}$ Local Government Act 2002, above n, 322, s 10

${ }^{325}$ Resource Management Act 1991, above n 283, s 30

${ }^{326}$ Bay of Plenty Regional Council, Local Governance Statement, August 2011

Available: http://www.boprc.govt.nz/media/102209/localgovernancestatementaug2011.pdf

Accesssed: 10/07/2014

${ }^{327}$ Bay of Plenty Regional Council, Organisational Structure Available: http://www.boprc.govt.nz/council/organisational-structure/

Accessed : 10/07/2014
} 
The BOPRC looks after the region's land, air, freshwater, coasts, passenger transport and regional development with a sustainable development focus. ${ }^{328}$

\section{Organisations' roles and responsibilities}

Each organization in the RTALSG has a different role to play. There are different areas of input and knowledge. In April 2007, a Memorandum of Understanding was signed by the three organizations in the RTALSG and the Crown. The MOU states that the Crown, as the owner of Crown stratum, provides a national perspective on lake management and matters of national importance. The Crown also funds 50 percent of the Rotorua Lakes Protection and Restoration Action Programme and a Ministry for the Environment representative attends meetings as an observer.

The MOU contains the following principles:

1. We recognise that preserving and protecting the Lakes will take a great deal of time, effort and financial resources to accomplish the restoration of the Lakes and the water quality.

2. We recognise there are legacy problems that have been created over a long period by actions that had impacts that were often unknown or uncertain.

3. We recognise that there are significant financial commitments that will need to be made over time by the parties. This document does not guarantee or commit the parties to any financial commitments.

4. We recognise that the restoration of the Lakes will require adaptive management, where actions and approaches may change as our understanding of the Lakes change with future research.

${ }^{328}$ Ibid. 
5. We recognise that cost sharing is appropriate but that the share from different parties may vary between lake projects and programmes.

6. We recognise that the timeframe to implement actions to address lake restoration is likely to exceed 10 years and that recovery in some lakes will take longer.

7. We recognise that all parties will be diligent in pursuing opportunities to achieve the goal of maintaining or improving the water quality of the Lakes.

The MOU contains roles to "define the contributions that the parties will bring to the partnership."329

It is stated to be the role of all Parties: ${ }^{330}$

(a) To regularly attend the Rotorua Lakes Strategy Group (constituted under the

Te Arawa Lakes Settlement Act 2006) to enable all parties to discuss and debate issues.

(b) To consider funding for specific projects on a case-by-case basis to contribute to agreed project outcomes.

(c) To facilitate consultation amongst and between the parties, and with other stakeholders.

\footnotetext{
${ }^{329}$ Memorandum of Understanding 2007, clause 4 Available: http://www.boprc.govt.nz/media/276243/lakes-070400rotorualakesstrategymemorandumofunderstanding.pdf Accessed : 22/02/2015

${ }^{330}$ Ibid.
} 


\section{i Te Arawa Lakes Trust}

The current members of the RTALSG representing Te Arawa Lakes Trust are current Chairman of the Trust, Sir Toby Curtis, and Deputy Chairman William Emery. Sir Toby Curtis is currently the RTALSG's chairman.

The Te Arawa Lakes Trust represents the iwi's wishes. Part of the Trust's role is to provide cultural advice on any action or inaction in relation to the Lakes.

\section{ii Rotorua District Council.}

The current RDC RTALSG members are Mayor Steve Chadwick, who is Deputy Chairman of the RTALSG, and elected councillor Karen Hunt. According to the MOU the Rotorua District Council is responsible for administering the relevant sections of the Resource Management Act 1991 and undertaking Resource Management Act administration (in accordance with section 31 functions) to implement the strategy for the Rotorua Lakes.

The RMA Section 31 functions include the control of the emission of noise and the mitigation of the effects of noise, the control of any actual or potential effects of activities in relation to the surface of water in rivers and lakes. ${ }^{331}$

The RDC must also provide and maintain the urban sewerage and storm water discharge infrastructure plan for and manage land uses within the lake catchments and plan for and to manage land uses within the lake catchments in association with Environment Bay of Plenty. ${ }^{332}$ The RDC in conjunction with BOPRC provides $50 \%$ of the lake restoration programmes' funds.

\section{iii Bay of Plenty Regional Council}

The role of BOPRC is to;

\footnotetext{
${ }^{331}$ Resource Management Act, above n 283, at s 31

332 Memorandum of Understanding, above 329
} 
1) implement the strategy for Rotorua Lakes;

2) administer the relevant sections of the Resource Management Act 1991;

3) monitor water quality issues, implement the Recreation Strategy and Aquatic Pest Management Strategy; and

4) plan for and manage land uses within the lake catchments fund 50 percent of the project in association with the district council. ${ }^{333}$

BOPRC must also undertake Resource Management Act administration in accordance with section 30 functions to implement the Strategy for the Rotorua Lakes. ${ }^{334}$

Section 30 functions are many and varied and include: the control of the taking, use, damming, and diversion of water, and the control of the quantity, level, and flow of water in any water body, the control of discharges of contaminants into or onto land, air, or water and discharges of water into water. ${ }^{335}$

Further responsibilities of BOPRC are: to take a lead role in water quality issues, to take a lead role in implementing the Rotorua Lakes Recreation Strategy and Aquatic Pest Management Strategy, and to plan for and to manage land uses within the lake catchments in association with RDC. ${ }^{336}$

\section{Summary}

The Te Arawa Lakes Deed of Settlement Act 2006 provides meaningful acknowledgements and apologies to Te Arawa and expresses the Crown's wish to move forward in partnership from past wrongdoings. The settlement transfers actual physical ownership of 12 lakebeds to Te Arawa although it does not address the ownership of water directly. A framework is provided for the beginning of a new statutory partnership building on the existing arrangements the organisations had in place. This framework looks like the fifth co-management example identified in chapter one were an indigenous group works with two or more state entities. The Act follows the recommendation in the

\footnotetext{
333 Ibid.

334 Ibid

${ }^{335}$ Resource Management Act, above n 283, at s 30

${ }^{336}$ Memorandum of Understanding, above n 329, clause 4
} 
co-management options report for a permanent entity for the management of the lakes to be established. Te Arawa obtained their goal to have permanent membership on the management entity as meaning that they can continue to work together to restore the lakes as a permanent entity. The way the co-management structure works in practice and the differing roles of each organization within it is assessed in chapter four. 


\section{Chapter Four: The Co-management Agreement in Practice}

\section{Introduction}

As outlined in chapter three, the RTALSG became a permanent statutory entity under the Act in 2006. Its establishment has been described as a "crucial factor in providing a foundation for the remedial and restorative initiatives for the Te Arawa Lakes." ${ }^{337}$ The focus of this chapter is on how the RTALSG works in practice.

Prior to the deed of settlement the joint committee had commissioned a report outlining the project structure and timeline for the Rotorua Te Arawa Lakes Programme (the Programme). Post-settlement this work continued. A deed of funding was then signed in 2009 requiring independent evaluation of the Programme every three years. The first evaluation found areas which needed to improve, recommending changes to the Programme's structure and processes. In response to the report, changes to the Programme management were made. This first evaluation and the subsequent changes to the Programme implementation is examined in this chapter which considers how the co-management functions in practice from the initial 2004 Programme document through to the current Programme Management Plan (PMP). The role of the RTALSG within this structure and how decisions, policy and plans are made are outlined in order to identify the type of co-management in place and the role of each organisation within it.

\section{Rotorua Te Arawa Lakes Programme}

The Te Arawa Lakes Programme aims to restore the Te Arawa Lakes' water quality and take measures to protect against further damage. The original Programme Document - the Rotorua Lakes Protection and Restoration Programme Document - was prepared in 2004 by Paul

\footnotetext{
${ }^{337}$ Human Rights and the Treaty of Waitangi, Crown and Tangata Whenua Available:http://www.hrc.co.nz/human-rights-and-the-treaty-of-waitangi/crown-tangata-whenuaengagement/te-arawa-rotorua-lakes-restoration-programme Accessed: 02/02/2015
} 
Dell. ${ }^{338}$ The 2004 Programme Document acknowledged that there was a lack of coordination between the different organisations' efforts to restore the lakes. The 2004 Programme Document then identified three key elements that needed to be linked in order to protect and restore the lakes in the long-term: governance, management and community.

The 2004 Programme Document focuses on four top priority lakes: Rotorua, Rotoiti, Ōkāreka and Rotoehu, as each lake has a different makeup and a different set of environmental issues and possible routes towards restoration. It is therefore a complex process to decide on a course of action for each lake, with a key area of the Programme being the development of action plans for each lake.

\section{A Action plans}

The action plan is the course of action for a particular lake; it is described as "the centrepoint of the Programme." 339 The plan outlines the options for improving the water quality of each individual lake after consultation with the community.

The 2004 Programme Document recognised that in order to develop action plans for individual lakes the complex set of issues faced by each lake needed to be understood. The Programme was therefore made up of eight elements, which are all interlinked. If the longterm water quality goals are to be attained, all the elements must be assessed. The elements are as follows: ${ }^{340}$

(1) Completed research and monitoring. This element involves the identification of information to aid understanding of each lake and its catchment area in order to develop options for managing each lake;

\footnotetext{
${ }^{338}$ Paul Dell, "The Rotorua Lakes Protection And Restoration Programme, Outline of Project Structure and Timeline Prepared” (Environment Bay of Plenty Environmental Publication, Whakatane, 2004)

${ }^{339} \mathrm{Ibid}$, at 10

${ }^{340}$ Ibid, at 9-10
} 
(2) ongoing research and monitoring. This element involves assessing nutrient loads and the effect of actions taken on changes to the water quality with a focus on pursuing long-term management options;

(3) funding assessment of the cost of the various actions that may be undertaken; this is inclusive of impacts brought about by land use change with possible economic impacts. This is necessary for engaging with the Crown for funding and the community;

(4) works: this element involves the identification of works that make short and long-term gains towards better water quality. Examples of works undertaken are sewage treatment, riparian management, fencing, treatment walls, wetlands treatment and changes in land-use;

(5) best management practices. This element involves the identification of the best practices to decrease the nutrient load from the different land usages by land owners. These reductions could be achieved through site effluent treatment systems; examples include pasture nutrient management from animals, fertiliser and effluent;

(6) education and communication. This element, identified as 'essential' concerns community involvement in decisions, in order to keep the local community engaged in steps to restore the lakes; and

(7) regulations, the regulation element being needed to maintain security and certainty; regulations may be in relation to regional water and land plan changes, stock in waterways, nutrient rules, on site effluent treatment. 


\section{Focus}

The focus of the action plan is to restore water quality and guard against further decline. The plan investigates the science and viability of each action and therefore provides a complete picture for sustainable development of the lake and its catchment. All the elements are considered in the development of the plan. The preparation process recognises that if something in the plan is inconsistent with a statutory planning document then that document may have to be altered to align with the action plan. In this area co-management streamlines the process, as RTALSG approval means the BOPRC and the RDC can bring their respective organisation's planning into line.

Every action plan has 'nutrient management' as an essential component: the plan must first define the existing catchment nutrient budget then determine what level of nutrient inputs is sustainable. This enables identification of nutrient reduction targets. From that point it is possible to formulate what actions are necessary and feasible within that catchment to achieve the reduction targets necessary for sustainable nutrient management. Following its development every action plan requires funding consent. ${ }^{341}$

\section{Activation}

An action plan is activated when the trophic level index (TLI) 24 of a lake exceeds the target TLI by 0.2 for two years in a row. ${ }^{342}$ The TLI is an indicator of the environmental quality of a lake. ${ }^{343}$ It is made up of two chemical and two biological components but provides information relating to the wider ecology of the lake and is linked to the land use in the catchment of the lake. ${ }^{344}$ There are working parties that have responsibility for developing and implementing the action plans. The working parties establish separate focus groups to

\footnotetext{
${ }^{341}$ Above $\mathrm{n} 339$, at 10

342 Ibid, at 10

343 Ibid at 10

${ }^{344}$ Ibid at 10
} 
evaluate specific actions. The Rotorua Te Arawa Lakes website now shows that there are detailed action plans for 9 of the 12 lakes within the Programme. ${ }^{345}$

\section{Programme funding}

The cost of the Programme is $\$ 144$ million. A deed of funding was agreed in June 2008 between the organisations and the Crown. Under the deed half the cost of the Programme is funded by the central government and the remainder funded jointly by the BOPRC and RDC. ${ }^{346}$ The current funding deed arrangements complete in 2017. However the BOPRC has committed to funding the Programme until 2022.

There are different paths to securing funding depending on the source. ${ }^{347}$ The portion funded through the Crown must be endorsed by the RTALSG but the portion funded by the BOPRC needs the BOPRC approval to progress. ${ }^{348}$ The RTALSG must seek funding approval from central government in certain circumstances and this can lead to delays in implementing approved actions. For example, RTALSG minutes record concern that nutrient reduction targets would not be met because the land use change agreements could not be entered into until the incentive scheme had been approved and established. The concern was with the time delays in obtaining Cabinet approval for funding redirection. ${ }^{349}$ The RLTASG dealt with this

\footnotetext{
${ }^{345}$ Rotorua Lakes Website Available: http://www.rotorualakes.co.nz/lakes Accessed :01/09/2014

${ }^{346}$ Press Release, April 2014

Available :http://www.boprc.govt.nz/news-centre/media-releases/april-2014/cabinet-decision-green-lightfor-lake-catchment-land-use-scheme/

Accessed: 01/09/2014

347 Programme Finance Plan

Available: http://www.boprc.govt.nz/media/295934/rotorua-te-arawa-lakes-strategy-group-meetingagenda-friday-30august-2013-part-1.pdf

Accessed: 22/02/2015

${ }^{348}$ Ibid.

${ }^{349}$ Minutes of the Rororua Te Arawa Lakes Strategy Group

Available: http://www.boprc.govt.nz/media/322168/20140319_rotoruatearawalakesstrategygroup-

19march2014_rev.pdf

Accessed : 01/09/2014
} 
by agreeing to send a further letter to the Minister to stress urgency of the funding with the Stakeholder Advisory Group writing a letter in support of the RTLSG. ${ }^{350}$

Funding has been identified as an issue by both TALT and BOPRC with the strategy group members interviewed both acknowledging that, for TALT, not holding the 'purse strings' has impacted on their position. TALT does not have government funding like BOPRC and RDC to participate in the RTALSG and therefore has to utilise settlement funds in order to be in the Programme. ${ }^{351}$ Indigenous groups in settlement negotiations need to be aware of this when agreeing to co-management - and consider whether they will have to fund their own involvement with the entity designed to effect redress for historical wrongs.

\section{2012 IQANZ report}

The current Deed of Funding agreement requires that a "Three Year Major Review" be undertaken prior to 1 July 2012, 1 July 2015 and 1, July 2018. The review must be by an independent body. Independent Quality Assurance New Zealand (IQANZ) undertook the first review with a 22 May 2012 report. This report is 'commercial in confidence' and therefore not available for public viewing. However the minutes of the RTALSG provide a summary of the IQANZ Report. ${ }^{352}$ This found the Programme was making progress toward realising the desired outcomes for the Rotorua lakes and that the work under the Programme was carried out by a number of exceptionally passionate and committed people at all

\footnotetext{
${ }^{350}$ Minutes of the Te Arawa Lakes Strategy Group Meeting, 19 March 2014

Available: http://www.boprc.govt.nz/media/322168/20140319 rotoruatearawalakesstrategygroup-

19 march2014 rev.pdf

Accessed : 22/02/2014

${ }^{351}$ Virginia Morrision, Environmental Justice and co-management of the Te Arawa Lakes, Environmental Management), University of Auckland, 2011

352 Report To: Rotorua Te Arawa Lakes Strategy Group Meeting, Date: 08 June 2012, Report From: Warwick Murray, Group Manager Land Management Update on Health Check Report for the Rotorua Lakes Programme, File Reference: 1.00250

Available:http://www.boprc.govt.nz/media/216085/rotorua_te_arawa_lakes_strategy_group_meeting_agen

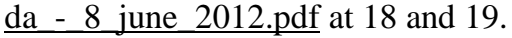

Accessed:06/06/2014
} 
levels. ${ }^{353}$ The recommendations made by the IQANZ in relation to governance and management are also summarised and the responses to these are examined below.

\section{A Recommendations}

\section{Governance}

Regarding governance, the IQANZ report made two recommendations:

(a) that a review of the terms of reference of the Rotorua Te Arawa Lakes Strategy Group to better reflect the proposed changes to the Deed of Funding to ensure that clear authority delegations for decisions are identified be undertaken; and

(b) that the RTALSG considers appointing an independent member to the Strategy Group as an enabler to drive the required management changes down into the Programme. 354

The PSG agreed with the recommendation to review the terms of reference for the Strategy Group to reflect intended changes to the Deed, and to ensure delegations are clear. However, on the second recommendation, the PSG reported to the RTALSG that they did not support the appointment of an independent member because the entity and its membership were formed under the Act and any change would require an amendment to the Act. The PSG acknowledged this was possible but believed the benefits of adding an independent member onto the RTALSG to assist in driving changes to the management of the Programme, would not outweigh the costs of doing so. ${ }^{355}$

In response to the report, the RTALSG directed the Partnership Steering Group to review the terms of reference for the Rotorua Te Arawa Lakes Strategy Group to ensure they reflect changes to the Deed of Funding and to ensure delegations are clear.

\footnotetext{
353 Ibid.

354 Ibid.

${ }^{355}$ Ibid.
} 


\section{Management}

The IQANZ report recommended that the Programme review management processes and enhance control for moving forward from the sewerage reticulation project. In addition, expenditure to support nutrient reductions from land use was increasing. The report identified a number of areas where improvements were needed in the management of the Programme to support the decision-making of the RTALSG. ${ }^{356}$

\section{B Programme Response}

The Te Arawa Lakes Programme 2012/2013 annual report ${ }^{357}$ (the 2012/2013 annual report) notes that significant changes were implemented to the management of the Programme in the last year following results from the 2012 IQANZ report:

(1) programme management principles were embedded into the management of the Programme;

(2) a new programme structure was implemented;

(3) appointment of programme manager and project co-ordinator effected;

(4) fortnightly meetings held with all partners to ensure greater collaboration between partners;

(5) a Programme Management Plan prepared; and

(6) a full review of all Programme contracts conducted.

\footnotetext{
${ }^{356}$ Ibid.

${ }^{357}$ Te Arawa Lakes Programme 2012/2013 annual report Available: http://www.rotorualakes.co.nz/vdb/document/403

Accessed : 01/02/2014
} 
The 2012/2013 annual report states that these changes have resulted in improved project planning, increased collaboration between partners and better Programme reporting. ${ }^{358}$

An internal audit report titled Internal Audit's Review of Rotorua Lakes Clean Up Project found that the 2012 IQANZ report was dated April 2012 with September 2012 the findings from the audit report should have been addressed in a more timely manner. ${ }^{359}$ The report highlighted that the findings and control deficiencies were 'high' and therefore warranted escalation to the Rotorua Te Arawa Lakes Strategy Group and the Ministry, to be dealt with immediately. 360

However the BOPRC had taken measures to address the issues highlighted in the 2012 IQANZ report; the new BOPRC programme manager had incorporated IQANZ findings in the current draft Programme Management Plan (PMP), Financial Management Plan (FMP), Change Management Plan (CMP) and Risk Management Plan (RMP). ${ }^{361}$ This demonstrates the ability to adapt and improve procedures and operations, incorporating independent feedback into the management of the Programme.

\section{Adaption - Programme Management Plan 2013}

Following the 2012 IQANZ report, the BOPRC developed a comprehensive and detailed 'Programme Management Plan' (PMP) in 2013 in order to make the Programme work as efficiently and effectively as possible. ${ }^{362}$ The PMP identified key success measures:

\footnotetext{
358 Ibid, at 21.

${ }^{359}$ Internal audit Report on Internal Audit's Review of Rotorua Lakes Clean Up Project,Prepared for Ronnie Chang Prepared by Internal Audit: David Sinkins, Director Noel Miranda, Associate Director Waning Chua, Assistant Manager Zac Parton, Auditor August 2013

Available: http://www.boprc.govt.nz/media/295934/rotorua-te-arawa-lakes-strategy-group-meetingagenda-friday-30august-2013-part-1.pdf

Accessed : 28/02/2014

${ }^{360}$ Ibid.

361 Ibid.

362 Programme Management Plan, above n 362, at 5.
} 
(1) Meeting community expectation's for water quality; and

(2) enhanced relationships and communication with partners and community. ${ }^{363}$

The scope of the Programme Plan is from 2008 - 2022. ${ }^{364}$ The PMP outlines the governance structure.

\subsection{Lakes Programme Structure}

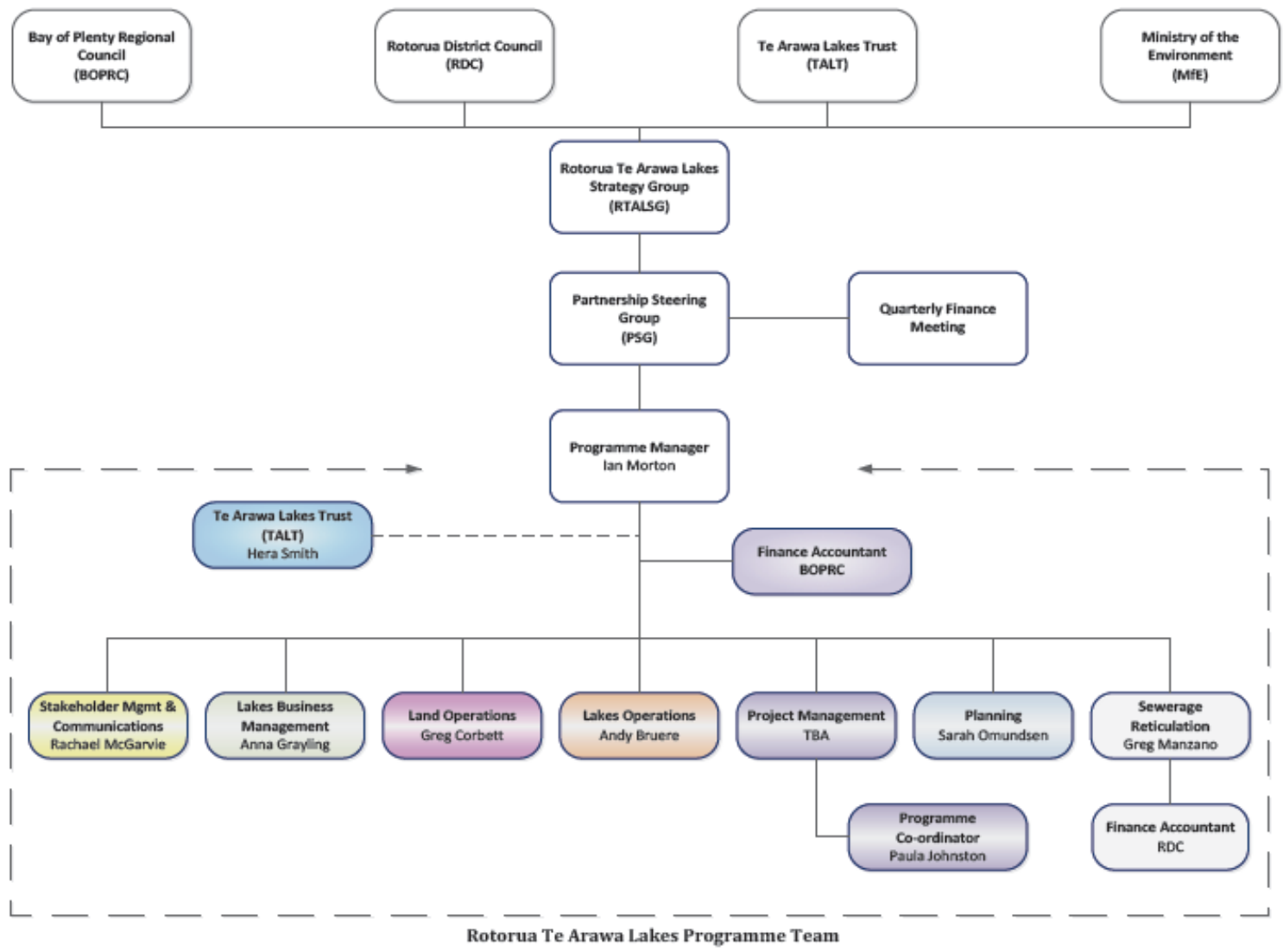

\section{A Rotorua Te Arawa Lakes Strategy Group}

The RTALSG sits at the top of the structure. Although it is the formal joint committee established under the Act it is an executive decision making entity, not an operational committee. The RTALSG first met in November 2006 and has been operating on its

Available: http://www.boprc.govt.nz/media/295935/rotorua-te-arawa-lakes-strategy-group-meetingagenda-friday-30august-2013-part-2.pdf Accessed: 01/06/2015

${ }^{363}$ Ibid, at 21.

364 Ibid, at 1 . 
quarterly meeting cycle since. ${ }^{365}$ The PMP identifies specific responsibilities of the RTALSG - these are as provided for in the RTALSG terms of reference. Specific responsibilities include:

(1) Providing leadership to organisations and community in relation to implementing the vision;

(2) identifying significant and emerging issues;

(3) preparing, reviewing, monitoring agreements, policies and strategies to achieve outcomes for the Lakes;

(4) identifying, monitoring and evaluating actions in place by relevant organisations;

(5) receiving reports from relevant organisations;

(6) being involved in preparation of statutory plans; and

(7) being involved in applications for activities (of significance) not addressed by existing policies.

The RTALSG's terms of reference and initial functions have been outlined in chapter three; they remain unchanged barring one alteration: a new clause 5.2.4 Group Chairperson, that reads: "The Group has agreed to rotate its Chairperson on an annual basis." been included as a result of discussions held during 2013. The consensus of the Group was to 'interchange' its Chairperson on an annual basis.

The evaluation report noted that the RTALSG is "a governance forum with a role in overseeing and providing policy guidance for the implementation of the Lakes Strategy by the partner organisations." ${ }^{367}$ The Programme's website states "The Rotorua Te Arawa Lakes Strategy Group is the overarching management group, operational decisions on the management of the Rotorua Te Arawa Lakes Programme are made at the Partnership Steering Group.” This group

\footnotetext{
${ }^{365}$ Roydon Somerville, Katia Fraser, North South Review of Terms of Reference (2010) Available on request from Bay of Plenty Regional Council Library, at 8.

${ }^{366}$ Minutes of Rotorua Te Arawa Lakes Strategy Group Meeting

Available: http://www.boprc.govt.nz/media/316047/rotorua-te-arawa-lakes-strategy-group-agenda-friday-

6-december-2013.pdf

Accessed : 05/07/2014

${ }^{367}$ North South Environmental Law Review of Terms of Reference, above n 365, at 16.
} 
meets monthly and is made up of senior managers from the three partner organisations and the Ministry for the Environment.

\section{Decision-making}

The 2004 Agreement outlined in chapter 3 provides that the New Zealand Standard Model Standing Orders for Meetings of Local Authorities and Community Boards (NZS9202: 2003) will apply to the group unless the members of the group unanimously agree to vary those orders as they apply to the group ("the Standing Orders"). Any agreement to vary the standing orders must be in writing and signed by each member or it will have no effect. ${ }^{368}$ The Standing Orders provide that the acts must be done and questions must be decided at a meeting by vote and the majority of members present and voting. ${ }^{369}$ Decisions are to be decided by majority vote. The mayor or chairperson or other person presiding at the meeting has a deliberative vote and in the case of an equality of votes, shall have a casting vote also.

The 2009 Evaluation of TOR said decisions are made by consensus (it appears a matter of convention and practice that decisions are made by consensus). The evaluation further observed that the RTALSG makes decisions collectively based on the reports and research presented to it at meetings, describing it as a high-level strategy committee and not an operational committee. Sir Toby Curtis explained that relationships between RTALSG members were strong and very important to the process. Sir Toby explained that prior to the formal meeting members meet for an informal chat to go over upcoming agenda items. ${ }^{370}$ The Honourable Steve Chadwick confirmed that this was an important part of the smooth operation of the RTALSG. ${ }^{371}$ Clearly the forming and building of relationships between members are important to the arrangements success. This is also Canadian experience in line with academic recommendations. ${ }^{372}$

\footnotetext{
368 Te Arawa Lakes Settlement Act, above n 131, at Schedule 1, Clause 6.

${ }^{369}$ New Zealand Standard Model Standing Orders for Meetings of Local Authorities and Community Boards (NZS9202:2003) 3.14.1 cl. 24, Schedule 7, LGA

${ }^{370}$ Interview with Sir Toby Curtis, Chairman of the Te Arawa Lakes Trust (Author, 22 June 2014)

${ }^{371}$ Interview with The Honourable Steve Chadwick, Mayor of Rotorua (Author, 9 September 2014.

372 The James Bay and Northern Quebec Agreement and the Northeastern Quebec Agreement - 2005 2006 and 2006-2007, Annual Report: Published under the authority of the Minister of Indian Affairs and Northern Development and Federal Interlocutor for Métis and Non-Status Indians, 2009
} 
The minutes of the RTALSG show it was presented with reports from the programme managers and asked for guidance and to make decisions based on those reports. ${ }^{373}$ The BOPRC has the infrastructure in place to run the operations and takes the high-level strategy to the RTALSG for consideration of changes to operating arrangements.

Under the 2004 Agreement, section 8 provides that the agreement may be amended with the consent of each of the organisations. At its meeting held on 12 November 2009, the RTALSG resolved that it would decide on the following changes to the Group's operating arrangements:

(a) include marae as venues for forum

(b) provide coordinated partner organisation programme information

(c) provide coordinated partner organisation programme monitoring and reporting

(d) celebrate success; and

(e) hold funding discussions.

The BOPRC, the RDC and TALT remain separate organisations with their distinct status but work together on the RTALSG. This has the hallmarks of the second type of co-management identified by Berkes: co-management as joint organisation. Where representatives of the state and groups of resource users might form joint management bodies or cooperative units and participate in joint decision making. Each participant keeps its authority and its relative autonomy.

\footnotetext{
${ }^{373}$ Te Arawa Lakes Strategy Group Meeting 6 December 2013. Available: http://www.boprc.govt.nz/media/316047/rotorua-te-arawa-lakes-strategy-group-agenda-friday6-december-2013.pdf Accessed : 06/06/2014
} 


\section{B Partnership Steering Group (PSG)}

The PSG is the group that forms policy and makes operational decisions on the management of the Rotorua Te Arawa Lakes Programme. This group meets monthly and is made up of senior managers from the three partner organisations and the Ministry for the Environment. ${ }^{374}$

\section{Membership}

The PSG is comprised of one representative from each of BOPRC, RDC, Ministry for the Environment and TALT. The PSG is supported as appropriate by staff from the Te Arawa Lakes Trust, Ministry for the Environment, Rotorua District Council, and Bay of Plenty Regional Council. Each meeting must have at least half plus one of the membership of the PSG to form a quorum. A chair and deputy chair are appointed from the membership. Each representative is a senior manager with either sponsorship or executive officer responsibilities in relation to the delivery of components of the Programme. The PSG members would therefore collectively represent the primary stakeholder organisations and also have some decision-making authority. The PSG may co-opt other expert advice and knowledge as required to achieve its purpose however co-opted adviser will not have voting rights.

The PSG membership with voting rights comprises:

- Chairman (BOPRC), Warwick Murray;

- General Manager Natural Resource Operations, Fiona McTavish (BOPRC);

- General Manager Strategy, Mark Rawson (RDC);

- Group Manager Economic \& Regulatory Services, Andy Bell (RDC);

\footnotetext{
${ }^{374}$ Rotorua Te Arawa Lakes Partnership Steering Group Terms of Reference; Available: http://www.rotorualakes.co.nz/governance Accessed: 06/06/2014
} 
- Group Manager Infrastructure Services, Cameron Sherley (MfE);

- Manager Remediation Projects, Roku Mihinui (TALT), Chief Executive Officer TALT;

- Executive Officer (TALT), Leilani Ngawhika; and

- an independent member from Continuum Consulting, Martyn Pinckard.

\section{Role}

The terms of reference for the PSG record that it was established to help give effect to the Deed of Funding between the Crown and Te Arawa, providing operational co-ordination between the organisations. ${ }^{375}$ The terms of reference further state that the PSG "develops and drives policy" ${ }^{376}$ sitting directly below the RTALSG in the governance structure. According to its terms of reference the PSG's role is "to provide integrated management oversight and direction to the activities of the Rotorua Te Arawa Lakes Programme." $" 377$ The PSG is also tasked with "enhancing the relationship between the parties to the Programme." 378

\section{Functions}

The following functions are recorded in the PSG's terms of reference:

1. Providing leadership to the managers of all relevant Deed of Funding work programmes operated by stakeholder agencies for the purpose of implementing the Programme;

\footnotetext{
${ }^{375}$ Ibid.

${ }^{376}$ Ibid.

${ }^{377}$ Ibid.

${ }^{378}$ Ibid.
} 
2. Providing support to the Strategy Group with respect to the identification and resolution of operational matters that have significant implications for the successful completion of the Programme;

3. Ensuring the development and maintenance of a cross-organisational management plan that includes, but is not limited to: programme scope, programme schedule, programme budget, programme quality management financial management, change management and risk management; and

4. Developing and implementing procedures for identifying, considering and deciding upon matters of an operational nature that pertain to management of the Programme including new interventions or changes to individual projects where such interventions / changes are likely to impact significantly and materially upon the successful completion of the Programme (these procedures should accommodate escalation of matters to the Strategy Group as appropriate and necessary); and

5. Monitoring progress in the implementation of the Programme and advise the strategy group accordingly.

\section{Limitation of Powers}

The PSG does not have any authority to commit the organisations and the Ministry for the Environment to any costs. The key purpose of the PSG is to give effect to the Deed of Funding agreement between the Crown and partner agencies. The group shall not have the authority to submit on regional plans or resource consent matters in its own right.

The PSG terms of reference state that: "the broader strategy and co-ordination role of the Programme is performed by RTALSG." This shows that it is not intended to be the overarching governance group but rather formulate policy options for the RTALSG to consider. 


\section{Operating philosophy}

The group will at all times operate in accordance with the following operating philosophy:

1. Giving effect to the cultural redress provisions of the Te Arawa Lakes Settlement (2006).

2. Being culturally sensitive observing, tikanga

3. Giving consideration to and balancing the interests of all water stakeholders in the region in debate and decision-making.

4. Working in a collaborative and co-operative manner using best endeavours.

\section{Meetings}

Under its Terms of Reference's the PSG must meet at least four times per annum with workshops and additional ad hoc meetings if appropriate and necessary. However in practice the PSG has been meeting monthly since its formation in July 2013.

Relationship between the RTALSG and the PSG

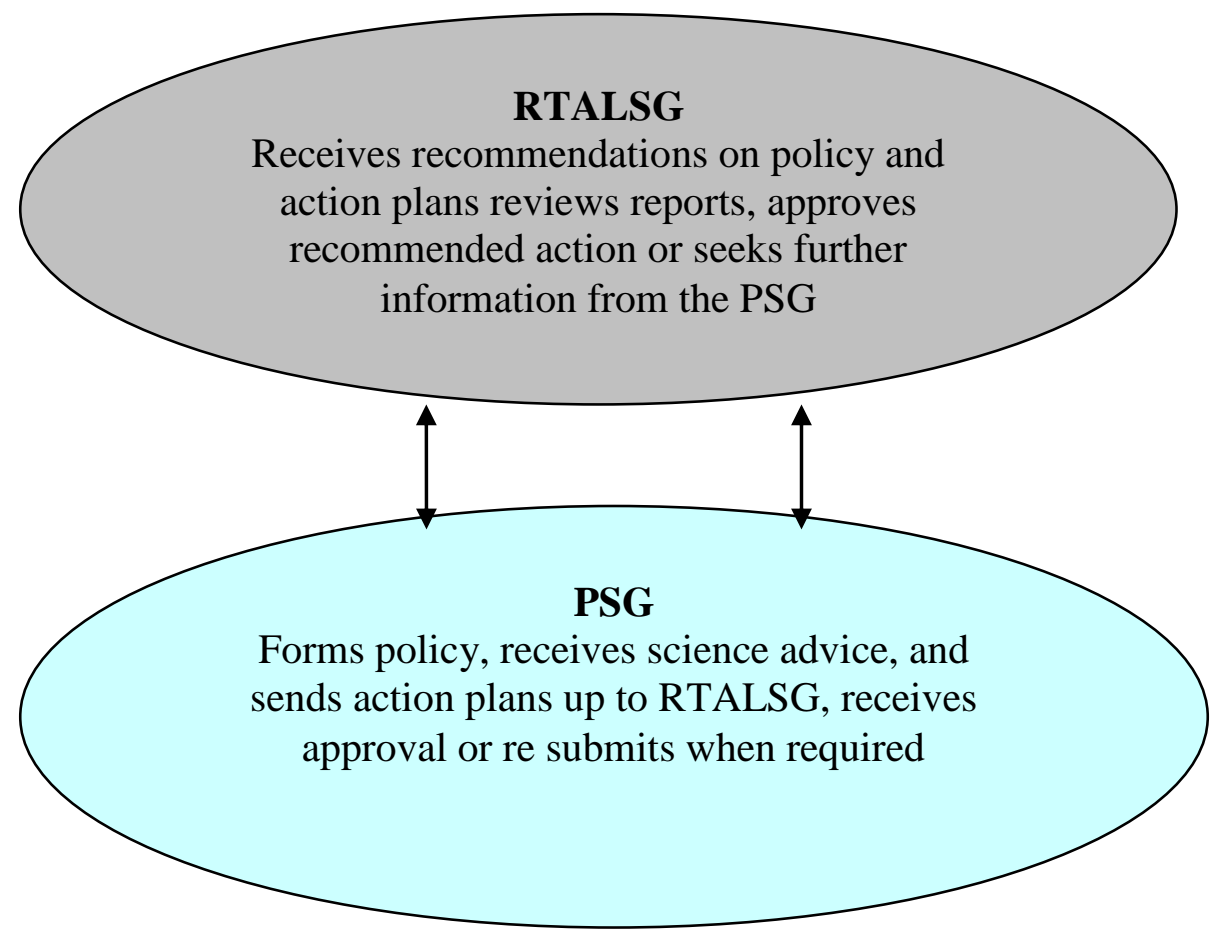


The diagram above shows the interplay between the RTALSG and the PSG. The RTALSG has the final approval and can seek more information before approving a particular plan but it is the PSG that receives the scientifuc advice from the advisory groups and uses this information to formulate policy.

This shows one of the benefits of co-management in practice as identified in chapter one - the utilisation of different stakeholders both private and private in order to design and implement the programme. This reflects what has been identified as good practice overseas. ${ }^{379}$

\section{Programme delivery team}

This team is responsible for the management of the everyday running of the Programme; they have quality assurance responsibilities that are recorded in the PMP. This includes maintaining the communication audit trail, maintaining all documentation and adherence to Programme. ${ }^{380}$

\section{The Programme Manager}

The responsibilities of the programme manager are outlined in the PMP as "administering and monitoring the quality assurance requirements in accordance with the approved standards and to ensure that any non-conformance within the Programme Delivery Team is resolved." 381 Any problems or escalations are also taken to the programme manager then taken to the Programme Steering Committee and finally the RTLSG if necessary. For issues that are internal to the specific organisations escalations will be through line managers. ${ }^{382}$

\footnotetext{
379 The Inuvialuit co-management arrangement also has an environmental steering committee, this is made up from members of the partners to the co-managemnet - three appointed by the IGC, one each by the federal, Northwest Territories and Yukon governments, and a chair by Canada with the consent of Inuvialuit. The screening committee examines all development proposals in ISR to determine whether they could have significant negative environmental impact or a potential impact on present or future wildlife harvesting (section 11, section 12(20-23) and section 13(7-12)). Proposals deemed deficient are rejected. Proposals considered to have a significant impact are referred to the review board or another appropriate body for public review. This determination of the appropriate referral body for the review is based on the opinion of the screening committee as to the adequacy and the willingness of other public bodies to assess and review the development proposal. Report of the Royal Commission on Aboriginal Peoples VOLUME 2 Restructuring the Relationship Canada Communication Group - Publishing Ottawa, Ontario K1A 0S9

${ }^{380}$ Programme Management Plan, above n 362, at 25

${ }^{381}$ Ibid, at 32

382 Ibid
} 


\section{Project co-ordinator}

The PMP provides that the monitoring of the Programme is done by the RTALSG with The Lakes project coordinator reporting directly to the RTALSG. The role of the coordinator is to develop and document the Rotorua Lakes Protection \& Restoration Action Programme and work with the various organisations and community to ensure its implementation. Representatives of the three organisations and, at the national level, central Government represent them at meetings with the community as required. The project coordinator links with each organisation separately. ${ }^{383}$

\section{Workstreams}

\section{Stakeholder management and communications}

This workstream is responsible for 6-monthly perception surveys of stakeholders and the wider community. They must provide quarterly Programme updates. Their specific activity is to engage and receive feedback on the development of Lake Rotorua Catchment Land Use Rules and Incentives. This workstream completed the Communications and Stakeholder Engagement Plan, developed new branding and name of the Programme, and was responsible for the launch of the Programme website. They provide regular communication updates and developed stakeholder database. ${ }^{384}$

\section{Land operations workstream}

The land operations work stream is responsible for tasks related to the land in and around each lake. This encompasses delivering land use change including converting gorse, lake weed control for amenity, weed harvesting for lakes operations, wetlands, providing an advisory service on nutrient/land management, implementing an incentive scheme, facilitating and implementing land use change projects with landowners, aquatic pest management, lakes

\footnotetext{
${ }^{383}$ Ibid.

${ }^{384}$ Annual Report 2012/2013, above n 357.
} 
biosecurity, continue LUC agreements, land TAG riparian management, biodiversity management, and providing support to landowner and community incentives. Part of their role in the Communication and Engagement Plan is to establish a decision-making support kit for landowners to help reduce nutrient loss. They are also responsible for the establishment of a Land Technical Advisory Group.

\section{Lake operations workstream}

The lake operations workstream is responsible for determining priorities and the overall direction of the lakes action plans. This includes projects such as lakes consents, approvals community input, engineering science, and monitoring iwi and hapu relationships, overseeing support for land change use. Some examples of the lake operations work stream projects are: the construction of the Tikitere Treatment Plant, building phosphorus detainment bunds, implementing catchment management plan actions in Rerewhakaaitu, working with lake owners to develop action plan for Lake Rotokakahi, developing an action plan for Lake Rotomahana, conducting post- implementation review of action plans for Lakes Ōkaro and Ōkāreka, determining need for landscape plan, and investigating weed management options in all lakes using weed harvester as an alternative to spraying. ${ }^{385}$

\section{Project management work stream}

The project management workstream is responsible for programme management. This includes financial management, contract management controls, and reporting requirements and planning. The measurement of nitrogen and phosporus reductions, program partners liason, reporting stucture, media liason, website and ministerial updates, annual report card generation and delivery. 386

\footnotetext{
385 Programme Management Plan, above n 362, at 26

386 Ibid
} 


\section{$5 \quad$ Policy and planning workstream}

The planning and policy workstream is responsible for understanding the regulatory requirements for all lakes. This team develops and conducts some implementation as well as ensuring alignment of policy across the organisations. ${ }^{387}$

This workstream is in charge of developing rules for Lake Rotorua with responsibility to undertake consultation, commence formal notification, and plan RMA process rules. The communication and engagement requirements are rule development consultation, lakes strategy awareness, other policy awareness and consultation, lakes strategy communication and engagement plan with partner organisations. Some examples of work completed by the policy and planning workstream are: adopting the Lake Okataina Action Plan, conducting the public consultation for the strategy for the lakes of the Rotorua District, establishing the Stakeholder Advisory Group, developing of allocation principles and framework for Lake Rotorua rules development, and gaining approval for the Gorse Policy. ${ }^{388}$

\section{Sewage reticulation work stream}

The sewage reticulation workstream is responsible for reviewing nitrogen and phosphorous tracking for all sewerage interventions, finalising design of Rotoiti and Rotomā sewerage schemes and completing Land Treatment System scoping and consultation. ${ }^{389}$

\section{E Workstream Leaders Group}

The leaders of each work stream manage the day to day aspects of the Programme and are responsible for management and delivery of the Programme initiatives. The terms of reference for the Workstream Leaders Group provide that they work together to deliver on the lakes Programme strategy and vision by undertaking the following: ${ }^{390}$

\footnotetext{
387 Ibid

388 2012/2013 Annual Report, above n 357

${ }^{389}$ Programme Management Plan, above n 362

390 Ibid.
} 
1. Assisting each other at regular meetings to solve problems and integrate work.

2. Peer review of key documents, for instance control plans and action plans, and make recommendations, and work on the collaborative development of RTAL Programme Plans.

3. Understanding of and contribution to current issues.

4. Change request review for changes less than $\$ 50,000$ as per the Change Management Plan process.

5. Fortnightly meetings to review and achieve a common understanding of overall Programme RAG status updates which include risks and issues, relevant actions, resource needs, and overall Programme impacts including achievement of Key Performance Indicators (KPIs).

6. Contribution to the resolution of problems that may prevent action plans or projects meeting their expected outcome, for example, resource constraints.

7. Contribution of ideas and thinking to new or intended initiatives and information sharing.

8. Ensure integration of all work streams to ensure RTALP objectives and outcomes are met.

9. Encourage communication and engagement of other key stakeholder groups to support the achievement of Programme outcomes, for example, Department of Conservation, Fish and Game, Farm/Agri-consultants.

10. Work to strengthen the TALT, RDC, and BOPRC partnership arrangements. 11. Work to strengthen ties with iwi, key stakeholders and the wider community

\section{A Decision-making}

While not a decision-making group, the WSLG provides review and endorsements, and makes recommendations. The WSLG also looks at areas where change could be made; they analyse the different options available and manage the risk management plan. This is a further example of this co-management arrangement utilising different skill sets and providing for selfevaluation and self-checking. 


\section{B Meetings}

At least half plus one of the membership must be present to form a quorum. Currently this number is six.

\section{Science Management Plan}

As the Programme's aim is the restoration and protection of the Rotorua Te Arawa Lakes, this project is at its core a scientific enterprise. The need for scientific research was recognised after the original strategy was adopted in 2000. This resulted in a 2002 agreement to fund a chair in Lakes Management and Restoration at the University of Waikato (UoW). The agreement has been renewed in 2007 and 2012 for a further five years. ${ }^{391}$

The objectives of the Science Plan are to provide expert advice and scientific thoroughness for the Programme. This includes direction for monitoring, research, and advice for the Programme for the next 12 months to 5 years. This direction enables team members to identify science gaps within the Programme creating a clear science pathway for the Programme. ${ }^{392}$ The Science Plan provides for new ideas to be tested. It is also a tangible document to show the scientific plan to the public and the organisations.

The Science Plan has systems for monitoring progress and the science will inform the policy of the Programme. The research means that action plans will manage catchments sustainably and in conjunction with the needs of the community. The science programme for the lakes is the responsibility of the Lakes Operations Manager. This means the responsibility has been delegated to a qualified professional hired by the Programme. This means the Programme can benefit from sound scientific evidence and advice from experts rather than have the top tier RTALSG members relying on outside advice.

\footnotetext{
${ }^{391}$ Science Plan - Rotorua Lakes Protection and Restoration Programme, 2014 Available: http://www.boprc.govt.nz/media/362742/rotorua-te-arawa-lakes-tuesday-3-june-2014.pdf Accessed : 15/04/2014 392 Ibid.
} 


\section{A Process for research}

The RTALSG appointed science advisory experts to form a Technical Advisory Group (TAG) to provide science and management advice to the Programme. This group is convened by the Lake Operations Manager BOPRC. They meet two to three times per year to provide science advice to the Programme; these are for both land and water and are known as 'technical advisory groups (TAGs). These groups are independent research groups. Independence groups are important because they provide an impartial perspective that is based purely on the science benefits rather than performing the practical analysis, this is an important element to a comanagement arrangement.

The RTALP science advisors initiate lake research opportunities and interventions for instream and in-lake restoration in response to BOPRC, the public and the research community. They then provide comment commonly through the TAGs. This is then communicated to the RTALSG via the action plan process where the science advisors and managers advise the RTALSG about the benefits and disadvantages of a specific intervention or research opportunity. These can then be included in actions in the action plan steps and implemented through that process. This means that the workflow for ideas to being implemented is carefully outlined and constructed to allow for the initiation of new research drawing on expert advice for actions plans.

\section{Advisory groups}

\section{A Stakeholder Advisory Group (StAG)}

\section{Membership}

The Group's membership is comprised of members from the Lake Rotorua Primary Producers Collective, Lakes Water Quality Society, Bay of Plenty Regional Council, Rotorua District 
Council, Te Arawa Lakes Trust, Office of the Māori Trustee, the forestry sector, iwi landowners and small block owners.

\section{Role}

The Lake Rotorua Catchment StAG was established in September 2012 to ensure the programme engages actively with stakeholders. The purpose of the StAG is to provide oversight, advice and recommendations on "rules and incentives" options that will achieve the nitrogen reduction targets needed from rural land to meet Lake Rotorua's water quality targets. This includes advice on implementation options and district and regional statutory plans. The StAG is involved in the development of policies on rules and incentives by considering options and the information available.

The StAG supported a publicly funded nitrogen reduction incentive scheme that was open and transparent and would drive competition and market efficiencies. ${ }^{393}$ The StAG has been actively involved in the development of policy on nitrogen allocation assessing the approach developed by the Primary Producers Collective, and in response to concerns developed a revised proposal. The establishment of the Stakeholder Advisory Group was expected to bring a new dimension to working with stakeholders to achieve reduction targets. ${ }^{394}$ Whether this expectation eventuated or not will probably form part of the next independent review of the Programme. However the StAG has recently advised on the operation and monitoring required to manage the de-stratification work at Lake Rotoehu, this shows the value of local stakeholders coming together to provide cohesive advice to the Programme.

The use of different stakeholders and community groups input into the Programme from across society, and not just utilizing government agencies, supports the theory of Kooiman's first governance perspective that governments are not the lone body able to mitigate against

\footnotetext{
393 Ibid.

${ }^{394}$ Minites of the Rotorua Te Arawa Lakes Strategy Group, 19 April 2013

Available http://www.boprc.govt.nz/media/276256/rotorua-te-arawa-lakes-strategy-group-agenda-friday19-april-2013.pdf

Accessed: $15 / 04 / 2014$
} 
societies problems. ${ }^{395}$ As discussed in chapter one this is one of the potential benefits of comanagement.

3 Meeting and reporting

The Group first met in November 2012 and meets monthly. StAG provides updates to the RTLSG.

\section{B Lakes Technical Advisory Group (Lakes TAG)}

\section{Membership}

The membership comprises representatives from the following core organisations: BOPRC, RDC, TALT, NIWA, UoW, GNS, and SCION. Lakes TAG membership can change reflecting changes to priorities, the evolving research, operational programmes, staff roles and staff availability.

\section{Role}

The Lakes Technical Advisory Group's terms of reference ${ }^{396}$ record that the purpose of the group is to provide technical advice on lake science and management to BOPRC, RDC and TALT in order to improve the water quality of the 12 Te Arawa lakes. The Lakes TAG operates as an informal forum of experts on lake water quality problems, causes, and solutions. ${ }^{397}$ The Lakes TAG will consider and make recommendations on lake, aquifer, catchment and

\footnotetext{
${ }^{395}$ Jan Kooiman, Maarten Bolvink, , The Governance Perspective, in Jan Kooiman, Maarten Bolvink Svein Jentoft and Roger Pullin (EDs.) Fish for Life: Interactive Governance for Fisheries, 2005, at 15.

${ }^{396}$ Appendix 1 - Final Terms of Reference (ToR) Lakes Technical

Advisory Group (21 May 2012)

Available: http://www.boprc.govt.nz/media/362742/rotorua-te-arawa-lakes-tuesday-3-june-2014.pdf

Accessed : 04/06/2014

${ }^{397}$ Ibid. clause 1
} 
ecological research linked to lake water quality status, trends and potential water quality solution. ${ }^{398}$

The Lakes TAG also provides guidance on nutrient load reductions necessary to achieve the water quality targets. In addition the Lakes TAG will provide advice on current and future risks to lake water quality, including climate and land use risks, hydrology (surface and groundwater) and land use. The Lakes TAG will advise on relevant operational matters such as current and proposed in-lake and in-stream actions. They will have input into monitoring regimes, results and analysis input to the development and review of non-statutory documents, including lake action plans. ${ }^{399}$

\section{Meetings and reporting}

The Lakes TAG meets three to four times per year and operates by consensus. The Lakes TAG convenor is BOPRC's lakes operations manager, Andy Bruere, who is responsible for circulating agendas and minutes to all Lakes TAG members. Formal reporting of Lakes TAG advice is via the RTALSG. The Lakes TAG does not have authority to initiate projects or incur costs. $^{400}$

\section{Land Technical Advisory Group (Land TAG)}

The specific science advice tasks of the Land TAG will develop in response to policy needs and stakeholder queries.

\section{Membership}

Membership in Land TAG is fluid, as research focus and priorities change. The membership has staff from BOPRC, RDC and TALT. While the Land TAG is focused on the Programme it

\footnotetext{
398 Ibid

399 Ibid

400 Ibid
} 
has representatives from: farm systems analysis, nutrient dynamics, farm economics, modelling catchment economics, modelling forestry horticulture, matauranga, rural extension and engagement, environmental management systems.

\section{Role}

The Land TAG will give advice on mitigation methods across current and potential future land uses and farm systems. Mitigation includes land use change, novel alternative land uses, developing technology and practices, and land management change. which includes good nutrient practices associated with major land uses and farm system types. ${ }^{401}$ The Land TAG provides advice in a range of areas including: cost-effectiveness, risks, gaps and priorities in land-based science, economic impacts and extension to rural landowners, specific mitigation techniques and proposals.

The Land TAG has input into BOPRC project briefs, including technical analyses to underpin statutory land use policy, rules and implementation and non-statutory incentives and other methods.

\section{Meeting and reporting}

The purpose of the Land TAG is to work as an informal forum of experts meeting four times annually and more if required. The Land TAG will operate by consensus. The Land TAG convenor is responsible for circulating agendas and minutes to Land TAG members and liaison with other groups such as the StAG. Formal reporting is to BOPRC on regional issues and RTALSG on lake programme issues.

\section{Sediment Advisory Group (SAG)}

\section{Membership}

${ }^{401}$ Land Technical Advisory Group, Terms of Reference Available: http://www.boprc.govt.nz/media/362742/rotorua-te-arawa-lakes-tuesday-3-june-2014.pdf Accessed : 04/06/2014 
The Sediment TAG (SAG) is convened by Professor David Hamilton, the group co-opts experts as required, including specific postgraduate students and staff from the University of Waikato, NIWA, and SCION scientists, and private sector experts with relevant expertise, products, and systems.

\section{Role}

The purpose of the SAG is to advise on lake sediment research. ${ }^{402}$ The SAG provides advice on remediation methods and potential for ecological and human health effects. ${ }^{403}$ SAG formulates criteria for recommending research into any particular product or technique, reviews sediment treatment proposals and trials brought to WQTAG and BOPRC and makes recommendations. SAG also provides input to other related Rotorua Lakes research initiatives, including the in-lake modelling of sediment nutrient dynamics and the response of lakes to interventions and climate change effects. ${ }^{404}$

\section{Meeting and reporting}

The SAG meets three - four times annually or as requested and operates by consensus. The SAG reports to WQTAG. Whilst the SAG does not have authority to initiate projects they can recommend projects for approval to BOPRC or make recommendations through the WQTAG. Any project approved will go through the funding channels of the funding deed, their meeting related costs are met by BOPRC.

\section{Aquatic Pest Co-Ordination Group (APCG)}

\section{Membership}

\footnotetext{
402 Sediment Advisory Group Terms of Reference Available: http://www.boprc.govt.nz/media/216981/20120608_rtalsg08june2012.pdf Accessed: 28/02/2015

${ }^{403}$ Ibid

404 Ibid
} 
The APCG members are from: Department of Conservation, Eastern Region Fish and Game Council, Bay of Plenty Regional Council, Rotorua District Council, Te Arawa Lakes Trust, Land Information, and New Zealand National Institute of Water and Atmospheric (Advisory).

\section{Role}

The purpose of the APCG is for the agencies responsible for managing aquatic pests to combine resources where possible and share information to manage aquatic pests in the Rotorua Lakes. The APCG prepares an annual plan for Rotorua Lakes aquatic pest management. The plan must take into consideration the roles and responsibilities of each organisation and the resources available for aquatic pest management. APCG member agencies will implement parts of the annual plan that apply to them and report back to APCG. Each member agency will contribute resources as appropriate within their mandate to help achieve the purpose and objectives of the group.

\section{Meeting and Reporting}

BOPRC provides administrative support to the group. Chairing and convening meetings is by mutual agreement between the member organisations.

\section{Vision and strategy for the lakes 2014}

The RTALSG produced a second comprehensive Vision and Strategy for the lakes of the Rotorua district (the 2014 Strategy), ${ }^{405}$ developed by a team comprised of staff from RDC, TALT and BOPRC. During development there was widespread consultation and community engagement, including a youth competition, a public workshop and a website that informed people of events related to the development of the next strategy and opportunities to be

\footnotetext{
405 Vision and Strategy 2014, above n 282.
} 
involved. ${ }^{406}$ The 2014 Strategy describes itself as "a living document that shows a pathway ahead but not the exact steps or when they will be taken." 407 It will be reviewed every ten years following its adoption to ensure the path is taking us in the right direction.

The strategy states it is important to be connected: ${ }^{408}$

Connected means a management framework is in place to enable statutory authorities, the community, iwi, businesses, other agencies and individuals to work together to achieve agreed long term goals for the lakes of the Rotorua district. To do this everyone must be well informed on the issues at hand and feel empowered to be part of the solution.

The 2014 Strategy outlines goals including:

1: The strategy is implemented collaboratively

2: The community is engaged and informed about lakes catchment issues

3: Knowledge is linked to action and adaption occurs

By 2014, an adaptive catchment management process is working including annual review, monitoring and reporting on strategy related initiatives. By 2016, decision-making will be undertaken considering experience, narrative, relationships (past, present and future), robust science, mātauranga, and socioeconomic knowledge

\footnotetext{
${ }^{406}$ Report To: Rotorua Te Arawa Lakes Strategy Group Meeting Date: 19 April 2013, File Reference: 1.00250 Significance of Decision: Low Report From: Stephen Lamb, Natural Resources Policy Manager Vision and Strategy for the Lakes of the Rotorua district

Available: http://www.boprc.govt.nz/media/276256/rotorua-te-arawa-lakes-strategy-group-agenda-friday19-april-2013.pdf Accessed; 09/06/2014

${ }^{407}$ Vision and Strategy 2014, above n 282

${ }^{408}$ Ibid
} 


\section{Adaptive co-management}

The definition of adaptive management referred to in chapter one outlined four key elements for the utility of an adaptive management arrangement. ${ }^{409}$ Each of these is evaluated in turn based on the information covered above.

\section{1) First, it is adaptive, and intended to be self-improving.}

The organisations collectively have expressed an intention to be adaptive and self-improving in the MOU which states: "We recognise that the restoration of the lakes will require adaptive management, where actions and approaches may change as our understanding of the lakes change with future research applies to this structure." ${ }^{210}$ This intention is also evident in the 2014 Strategy with goal three providing: "Knowledge is linked to action and adaption occurs" The aim is by 2014 that an adaptive catchment management process is working including annual review, monitoring and reporting on strategy related initiatives. ${ }^{411}$

2) Second, it is a well-designed, formal approach that connects the power of science to the practicality of management

The Agreement, the Act, and the MOU provide the formal structure for the RTALSG. The Programme itself could be categorised as formal and 'well-designed' with the governance structure in place and documentation covering all aspects of the Programme, from management with the PMP, Science with the SMP and communication and engagement with stakeholders through the CEP. Further, there are detailed terms of reference for the operational groups such as the PSG and workstream leaders. The science is provided by the various advisory groups described above and is incorporated into the Programme's management through advice and reports received by the workstreams and the PSG. This in turn informs policy and planning providing for scientific knowledge to be used when formulating lakes restoration strategy.

\footnotetext{
${ }^{409}$ F.L Bunnell, B.G. Dunsworth, L. Kremsater, D. Huggard, W.J. Beese, and J.S. Sandford, Forestry and biodiversity - learning how to sustain biodiversity in managed forests. UBC Press (in press), 2007, at 1.

${ }^{410}$ Memorandum of Understanding above $\mathrm{n}$, at $\mathrm{s} 3$ principle 4

${ }^{411}$ Vision and Strategy 2014, above n 282
} 
3) Third, it is an on-going process for continually improving management, so the design must connect directly to the actions it is intended to improve.

The Programme still encompasses and provides for the elements identified in the original Programme Document. The processes for completing these elements have been improved with the development of the different work streams. Element 2 is ongoing research and is covered by the SMP under which the processes for triggering research are defined. This promotes research being narrowed to the most relevant and promising ideas. The ongoing process for management improvement this is clear from the 2000 Strategy through to the 2014 Strategy. The response of the Programme to the IQANZ report shows widespread improvement to the different components of the Programme. This is a continual process as the PMP is reviewed annually. The design of the PMP the SMP the CEP all connect directly to actions undertaken by the work streams and science advisory groups. The plans relate to improved management structure, and improved science flows.

4) Fourth, although experimental approaches can be incorporated into adaptive management effectively, operational approaches and scales are emphasized to permit direct connection to the efforts of managers.

The PMP provides for operational detail with provision for a direct line to the managers, with the work-streams feeding up to the PSG, which in turn reports to the RTALSG. In light of the Programme's ability to implement widespread improvements and change in response to the IQANZ report it can be classified as an adaptive co-management system. The Honourable Steve Chadwick, deputy Chair of the RTALSG, described the system as a continuous cycle with ideas feeding up to the RTALSG and then being referred back down the PSG for further refinement or information as required. 


\section{Summary}

The three 'common underpinnings' of co-management identified by Berke and outlined in chapter one are: that the concept of co-management is associated with natural resources management; co-management is viewed as some form of partnership between public and private actors; and co-management is not a fixed state process that takes place along a continuum. The co-management is in respect of the Te Arawa Lakes a, a natural freshwater resource, there is a partnership between the local government and the private TALT therefore it involves public and private actors and finally it takes place along a continuum and is not fixed or defined as a particular form of management.

The Programme draws on multiple community groups the use of different advisors through the PSG and the various science advisory groups aligns with the recommendation at world summit in Johannesburg that broad participation in policy and decision making is required for sustainable development. ${ }^{412}$

The RTALSG has been described as an overarching strategy and high-level committee. ${ }^{413}$ In practice it is the PSG that does much of the actual policy formulation and guides direction, however the PSG must always revert back to the RTALSG therefore the power of decision making still resides with them although the PSG can be considered the operational arm.

The co-management has evolved into an adaptive management system through implementing changes based on the IQANZ report and other feedback. As outlined in chapter one, comanagement that succeeds naturally morphs into adaptive co-management. Adaptive management or 'learning by doing co-management' was identified as being advantageous for indigenous people as opposed to a rigid inflexible structure and this appears to have been satisfied by the system adopted, as described above. The incorporation of the traditional relationship of Te Arawa and the environmental outcomes of the Programme are assessed in the next chapter.

\footnotetext{
412 Johannesburg Declaration on Sustainable Development A/CONF.199/20

${ }^{413}$ North South Review of terms of Reference, above n 365.
} 


\section{Chapter Five: Te Arawa Involvement and Environmental}

\section{Outcomes}

\section{Introduction}

This chapter focuses on the results from the co-management arrangement, specifically the level of involvement for Te Arawa and the environmental outcomes the Programme has achieved, considering in particular in-lake interventions and land solutions: "At a time when many areas across the country are faced with declining water quality it is great to have several taonga improving. It's testament to the Programme's innovation and can-do approach. ${ }^{\circ 414}$

\section{Te Arawa involvement}

The lakes are part of us. Every nook and cranny we have a name for, they are named after prominent ancestors and those names are still used today as though they are still living 415

The role of TALT has been described as a cultural lens overseeing every element of the Te Arawa Lakes Programme. ${ }^{416}$ The recognition and provision for Te Arawa's relationship with the lakes appeared to be forefront in the minds of the drafters of the 2000 Strategy for the lakes, with this vision: ${ }^{417}$

The lakes of the Rotorua district and their catchments are preserved and protected for the use and enjoyment of present and future generations, while recognising and providing for the traditional relationship of Te Arawa with their ancestral lakes.

\footnotetext{
414 Sir Toby Curtis, article, Great news for Rotorua lakes water quality, Thursday, 2 October 2014 12:00 a

415 Toby Curtis, Chairman Te Arawa Lakes Trust, 2000 Vision and Strategy for the Lakes

Available:http://www.boprc.govt.nz/media/276256/rotorua-te-arawa-lakes-strategy-group-agenda-friday19-april-2013.pdf Accessed: 02/02/2014

${ }^{416}$ Ibid.

${ }^{417}$ Ibid.
} 


\section{A 2000 Vision and Strategy}

The 2000 Strategy identified the challenge: to recognise and provide for the traditional relationships of Te Arawa as tangata whenua with the lakes, as set out in the RMA, taking account of the principles of the Treaty of Waitangi. One of the strategy's key goals was to establish in partnership with Te Arawa a co-management framework that achieves the best integrated management, establishing meaningful and binding working relationships with the iwi/hapu and their ancestral lakes. The 2000 Strategy identified problems such as lack of integrated management, ecological and institutional, of the lakes and their catchments. Misunderstanding of Te Arawa's traditional relationship with the lakes was identified in the 2000 Strategy, occurring through lack of knowledge of the importance of traditional relationships to Māori and lack of opportunity to acknowledge and understand those things of importance to Māori. The difficulty of combining physical sciences (quantitative) with metaphysical knowledge (qualitative and spiritual) was identified.

As outlined in chapter one, Coombes ${ }^{418}$ warned that co-management can co-opt Māori rights to land and resources, it is possible for the indigenous group to enter into a co-management agreement that does not bring the expected level of power sharing. If co-management is a redress option then the indigenous participation needs to be real, meaningful and it needs to reflect the actual aspirations of the indigenous group in practice, The Programme looks to be trying to incorporate more traditional aspects of Te Arawa's relationship with the lakes: clearly they do not exercise the authority they once had and a limitation of co-management is that it does not provide for the full ownership and full control by the indigenous group.

\section{B 2014 Vision and Strategy}

In the 2014 Strategy, goal number four was that the lakes' catchment is managed through Te Arawa values. This is an ongoing goal and three targets were identified for achieving this:

\footnotetext{
${ }^{418}$ Brad Coombes, Contested conservation legacies and the co-option of Māori resistance through comanagement, Senior Lecturer, School of Geography and Environmental Science, University of Auckland.
} 
1) an agreed protocol between partner organisations defining terms of Te Arawa engagement and involvement in lakes catchment management by 2013;

2) waahi tapu and significant sites management plans for the lakes catchment have been completed by 2015; and

3) Lakes catchment management reflects Te Arawa values.

\section{Examples of Te Arawa Initatives}

\section{A Tau Kōura}

An example of traditional Te Arawa engagement with the lakes is the Tau kōura. This was the dominant traditional fishing method for harvesting kōura used by Te Arawa. The method entails laying bundles of bracken fern on the lakebed. This creates a haven for the kōura and the bundles are then retrieved and analysed. Information gained from this can be used to inform sustainable harvesting levels. It has advantages as a monitoring tool over conventional methods, such as baited traps and dive surveys, as it samples all kōura size classes, can be used in turbid waters and at a wide range of depths, and does not require expensive equipment or specialised expertise. Data gathering and analysis for the purpose of understanding the state of the resource is the first of the seven categories identified by Pinkerton ${ }^{419}$ that can benefit from co-management as outlined in chapter one of this paper.

The use of Tau kōura revealed that the kōura changed depth depending on the level of stratification of the lake. For instance when the water was mixed, the kōura were present at depths down to 21 metres; however, when the lake was stratified, kōura moved to waters above 19 metres. This information was used to recommend that hypo-dosing and sediment capping treatments be carried out when Lake Rotorua is stratified. ${ }^{420}$

\footnotetext{
${ }^{419}$ Evelyn Pinkerton (Ed) 1989, Cooperative management of local fisheries: New directions for improved management and community development. Vancouver Canada: University of British Colombia Press E.

${ }^{420}$ Kusabs I \& Quinn J 2009, Use of a traditional Māori harvesting method, the tau kōura, for monitoring kōura (freshwater crayfish Paranephrops planifrons) populations in Lake ${ }^{420}$ Rotoiti, New Zealand, New Zealand Journal of Marine and freshwater research 43: $713-722$
} 


\section{B Koaro Restoration}

The decimation of the koaro resource was outlined in Chapter two. TALT is now involved in a programme to protect and ideally restore the koaro population. This programme is a joint effort between Ngāti Rangiwewehi, BOPRC, Fish \& Game, Department of Conservation, NIWA and the Hamurana Springs Incorporated Society. The Hamurana Springs were chosen as the site to begin action, with a trout barrier installed in May 2012 to prevent trout predation. The barrier stopped the trout from accessing part of the stream meaning that the koaro had a safe space to breed. Initial monitoring in July 2012 and February 2013 still showed overall numbers were low but monitoring in July 2013 showed the numbers of koaro had significantly increased, providing hope that the koaro population would continue to breed and grow in size. ${ }^{421}$

\section{Cultural Health Framework}

A new initiative TALT is developing is a Cultural Health Framework (CHF) for the Te Arawa Lakes - this will recognise Te Arawa's role as the landowner of the lakebeds, kaitiaki and is described as "a way to provide for the traditional relationship with their ancestral lakes." ${ }^{422}$ It is envisioned that the CHF will be developed by recognising iwi relationships with the lakes, reflecting Te Arawa values, linking western scientific methods and matauranga as part of lake and ecosystem health. The Programme expects that the CHF will have multiple benefits. The framework would serve as a tool for providing some meaningful health measures for the lake Programme in terms of Te Arawa's vision and cultural links to the lakes. Such measures will include a status indicator, a mahinga kai measure and a cultural lake health measure. ${ }^{423}$ TALT is working with Waikato Iwi and BOPRC staff on the cultural health index framework, which would be reported back to the Committee at a future date. ${ }^{424}$

\footnotetext{
${ }^{421}$ Ian A. Kusabs, Use of a traditional Māori. harvesting method, the tau ko-ura, for monitoring ko-ura (freshwater crayfish, Paranephrops planifrons) in Lake Rotoiti, North Island, New Zealand.

422 Rotorua Te Arawa Lakes Programme, Annual Work Programme, 2014 / 2015, at p12. Available: http://www.boprc.govt.nz/media/362742/rotorua-te-arawa-lakes-tuesday-3-june-2014.pdf Accessed : 22/02/2014

423 Ibid.

${ }^{424}$ Meeting of Te Arawa Lakes Strategy Group, 19 March 2014
} 
The SMP acknowledges that there needs to be a wider range of lake health indicators, with a particular focus to strengthen Māori cultural indicators to enable a better understanding of lake health with respect to Māori values. ${ }^{425}$ As identified by Tipa the incorporation of indigenous knowledge with non-indigenous knowledge is challenging. ${ }^{426}$ The collaboration between the co-management partners appears to help mitigate this and the acknowledgement by the SMP shows the Programme is addressing the incorporation of indigenous knowledge into the Programme.

\section{Identification of culturally sensitive areas}

The 2013-2014 Update from TALT identifies a new project that TALT is leading, to identify significant cultural sites around Lakes Rotorua, Rotoiti, Rotoehu, Rotoma, Tarawera, Ōkāreka. The purpose of the project is to identify priority areas along the lakeside of the lakes identified in the Te Arawa Lakes Settlement Act 2006 that are considered culturally sensitive to hapu, and which lakes structures is a prominent feature. RDC seeks to identify culturally sensitive areas that require a district plan response with regard to lake structure provisions.

\section{Summary}

In chapter one the potential dangers for indigenous people entering into co-management arrangements were outlined. These included marginalisation, the potential for further conflict, the difficulty inherent in synthesising indigenous knowledge and non-indigenous knowledge.

Available: http://www.boprc.govt.nz/media/322168/20140319_rotoruatearawalakesstrategygroup19march2014_rev.pdf

${ }^{425}$ Report To: Rotorua Te Arawa Lakes Strategy Group, Meeting Date: 03 June 2014 Andy Bruere, Lakes Operations Manager, Rotorua Te Arawa Lakes Programme Science Plan File Reference: 4.00842, Lakes Programme Science Plan

${ }^{426}$ Gail Tipa and Richard Welch "Co-management of Natural Resources: Issues of Definition From an Indigenous Community Perspective” (2006), Journal of Applied Behavioral Science 42, at 380 
The specialty science groups and advisory groups that the Programme draws on for guidance as outlined in chapter four are all based in western science. The introduction of the cultural health index provides for traditional knowledge and mautauranga Māori. It is a concrete recognition of Te Arawa's cultural input to the management of the lakes. Clearly Te Arawas traditional customs and protocols for dealing with the lakes hold a wisdom that was not present in the actions of the Crown agencies that allowed the towns sewage to be released into the lakes. As identified in chapter two, water is never allowed to be contaminated by human waste. These practices in relation to water mean that quite naturally Te Arawa would avoid the Tragedy of the Commons as they would not pollute or overuse a resource, which to them was a living being to be protected, respected and sustained.

Chapter one also identified that the dangers for indigenous people in achieving real power sharing can be mitigated by combining adaptive management with co-management. The three key steps identified by Robinson were; preparing for the partnership, this key step was achieved because the parties worked together from the late 1990's with each having different responsibilities both legislative and moral, the formulation of the 2000 Strategy was an involved, co-ordinated response between the parties to the disparate environmental state of the Te Arawa Lakes. These interactions and projects were preparation and relationshipbuilding between the organisations, laying the foundations for entering into a permanent comanagement agreement. Robinson's second key step is that the agreement be negotiated; the agreement was negotiated, although TALT initially sought a greater than one third share in the agreement. ${ }^{427}$ Robinson's third key step was that the co-management agreement is implemented through learning by doing - chapter 4 has demonstrated that this is an adaptive co-management arrangement and the Programme's management systems have evolved and progressed as a result of trial and error and external auditing.

TALT is also involved with LERNZ (Lake Ecosystem Restoration New Zealand) - which informs the science behind the in-lake interventions to help clean the lakes - as well as in the Governance Group and the End User Group. TALT is engaged throughout the different

\footnotetext{
${ }^{427}$ Interview with Sir Toby Curtis, Chairman of the Te Arawa Lakes Trust (Author, 22 June 2014)
} 
levels of the Programme, at the policy level on the PSG, on the workstream level and at the overarching governance level on the RTALSG. It is important that each partner be involved from the ground up because if TALT was absent from the PSG they would not be involved in the formation of policy - as noted in chapter 1, forming policy is the 7th management task identified by Pinkerton. If the indigenous group is not part of this then they are excluded from a critical part of the management process. Helpfully, this problem has been avoided in the Te Arawa Lakes system.

\section{Environmental Outcomes}

\section{A Ohau Diversion Wall}

\section{i Situation}

Lakes Rotorua and Rotoiti are connected by the Ohau channel with water flowing from Lake Rotorua directly to Lake Rotoiti. The water flowing through the Ohau channel contains high levels of nitrogen and phosphorus. This contributes over 70\% of Lake Rotoiti's nutrients.

\section{ii Action}

To address the unchecked flow of water between the lakes a wall was built in 2008. The wall diverts the water previously flowing into Lake Rotoiti down into the Kaituna river. Made of steel and concrete, the wall is 75 metres wide and 1275 metres long, beginning at the Ohau channel entrance and ending at Te Akau Point. The wall is embedded into Lake Rotoiti's lakebed and extends just above the water level.

It is a major intervention and as such has potential effects on the environment both the shortterm and long-term effects of the Ohau Channel diversion on Lake Rotoiti and the Kaituna River are uncertain. The role of the BOPRC and RDC was to grant the consents to BOPRC in October 2005 subject to conditions. The $\$ 10$ million cost was met by BOPRC and the central government. The local community was involved in the design of the structure based on feedback from the public at meetings and hui.

iii Result 
The diversion wall prevents 180 tonnes of nitrogen and 15 tonnes of phosphorus entering the main body of Lake Rotoiti from Lake Rotorua each year through the Ohau Channel. This has resulted in $70 \%$ of nutrients being diverted to the Kaituna river. ${ }^{428}$ It is not expected to have any significant impact on Kaituna River quality. The diversion is expected to improve Lake Rotoiti's water quality within five years. Lake Rotoiti had the best water quality in decades with results showing the internal load of nitrogen and phosphorus levels were reduced. ${ }^{429}$ The diversion wall will make long-term improvements of itself but it will be assisted by sewerage reticulation ${ }^{430}$ being implemented in some communities along with improvements to septic tank systems. The koura population was greatly improved since the installation of the diversion wall. ${ }^{431}$ So in summary the diversion wall is an example of in lake interventions which can have immediate positive effects.

\section{B Cyanobacterial blooms - alum dosing}

\section{i Situation}

There have been cyanobacterial (blue-green algae) blooms in some of the lakes caused by excessive levels of nutrients. Certain strains of cyanobacteria are toxic (cyanobacterial toxins can attack various parts of the body, such as the liver or nervous system), meaning the water can be unsafe for swimming and harmful to aquatic life. ${ }^{432}$ The RTALSG must be diligent to the potential of algal blooms and must have a rapid response in place.

\section{ii Action}

\footnotetext{
${ }^{428}$ State of the Rotorua/Te Arawa Lakes 2009-2010, An update on the current state of the Rotorua/Te Arawa Lakes and what actions are being taken to protect and restore them, above n, at 13.

${ }^{429}$ Annual Programme Report 2012-2013 at 15.

Available: http://www.rotorualakes.co.nz/vdb/document/403

Accessed: 10/11/2014

${ }^{430}$ Ohau Diversion Wall

Available: http://www.boprc.govt.nz/environment/water/rotorua-lakes/ohau-channel-diversion-wall/ Accessed: 09/11/2014

${ }^{431}$ Meeting of the Rotorua Te Arawa Lakes Strategy Group

Available: http://www.boprc.govt.nz/media/276256/rotorua-te-arawa-lakes-strategy-group-agenda-friday-

19-april-2013.pdf

Accessed : 15/02/2015

${ }^{432}$ Restoring the Rotorua Lakes: The ultimate endurance challenge, above n, at 13.
} 
The BOPRC monitors the level of cyano-bacteria ${ }^{433}$ one action that they take when levels are high is to apply alum to the lake surface by boat. The alum has the effect of locking up the nutrients so that the algae cannot feed off them and this can potentially halt a toxic algal bloom.

iii Result

In 2011 high levels of cyano-bacteria were recorded and using alum dosing the BOPRC successfully prevented an algal bloom.

\section{Hamuranga Sewage Scheme}

\section{i Situation}

Lake Rotorua needs reduction in nitrogen imput.

\section{ii Action}

Hamurana sewerage scheme was completed in late October 2012. There were 525 households connected removing nearly six tonnes of nitrogen from the lake annually. The completion by Rotorua District Council of the Hamurana Sewage Scheme was the last Deed funded Sewage Scheme scheduled for the Rotorua catchment. It involved: floating wetlands, sewerage reticulation, sewerage plant upgrades, and a treatment plant for geothermal nitrogen.

iii Result

This resulted in 1007 households previously on septic tanks now being reticulated to a central treatment plant. A further 501ha of planting in the Rotoehu catchment reduced nutrients from land use to Rotorua by 2.5 tonnes of nitrogen.

\footnotetext{
${ }^{433}$ Rotorua Lakes Latest News Available:http://www.rotorualakes.co.nz/latest_news/m/2/yr/2014/id/253/Rapid\%20response\%20to\%20inc rease $\% 20$ in $\% 20$ algae $\% 20$ in $\% 20$ okawa\%20Bay Accessed: $15 / 02 / 2015$
} 
The RTALSG have a projected goal of reducing the nitrogen input into Lake Rotorua by 50 tonnes per annum though. This leaves an annual balance of 270 tonnes to be reduced from the pastoral sector to achieve the 320 tonne reduction target.

\section{Actions examples of success for 2012 and 2013}

The Programme provides an annual "snapshot of progress" during 2012. The following successes were reported: ${ }^{434}$

1) Completed zeolite trial to test best option for removing nitrogen from geothermal sources in Lake Rotorua;

2) Established the Lake Rotorua Stakeholder Advisory Group to provide insight, advice and recommendations for development of rules and incentives for Rotorua catchment;

3) Launched new programme website www.rotorualakes.co.nz;

4) Renewed University of Waikato Chair of Lakes Management and Restoration to provide science support and knowledge for programme;

5) Lakes Rotoiti and Rerewhakaaitu met their water quality targets;

6) Completed 501 hectares of planting for land use change agreement in Lake Rotoehu catchment removing four tonnes of nitrogen;

7) Seven detainment bunds installed in Lake Rotorua catchment to trap phosphorus in storm events; and

8) Successful initial trialing of aeration devices in Lake Rotoehu ${ }^{435}$

The achievements of the Programme were noted by Bay of Plenty Regional Council Chairman Doug Leeder "Five lakes were at their target this year which is an incredible result

\footnotetext{
${ }^{434}$ Rotorua Te Arawa Lakes Programme - Snapshot of Progress 2012-2013 http://www.rotorualakes.co.nz/vdb/document/402

Available: http://www.rotorualakes.co.nz/vdb/document/402

Accessed : 06/06/14

${ }^{435}$ Ibid
} 
for the programme and the community," he said. General Manager Environmental Delivery Warwick Murray said Lakes Rotorua, Rotoiti, Ōkaro, Rerewhakaaitu and Rotomahana met their water quality target and Rotoehu, Tikitapu and Rotoma were close. "We have had a deliberate strategy of taking both short-term and long-term actions. The short-term actions mean the community can enjoy improvements in the lakes now while our long-term actions are implemented and take effect," ${ }^{436}$

\section{Summary}

The role of TALT is increasingly incorporating traditional Te Arawa tikanga and values into the management of the Te Arawa Lakes. The full effect of the CHI cannot be measured at this time but the move towards a greater emphasis on the cultural and spiritual health of the lakes is in keeping with the traditional role of Te Arawa as the owners and guardians of the lakes.

The improving health of the lakes shows the environmental success the Programme has been able to achieve. The co-management arrangement has clearly obtained the expert advice required to make informed decisions regarding in lake and land interventions described above which have significantly improved the quality of the Te Arawa Lakes.

\footnotetext{
${ }^{436}$ Media Release October 2014

Available:http://www.boprc.govt.nz/news-centre/media-releases/media-releases-2014/october-2014/greatnews-for-rotorua-lakes-water-quality/

Accessed: 22/02/2015
} 


\section{Conclusion}

Chapter one outlined the emergence of modern co-management through the fisheries collaspe and the Boldt decision, both the benefits and the potential dangers of comanagement for indigenous people were discussed. Chapter two provides the history of the Te Arawa people with the lakes - both their traditional relationship and the legal history with the Crown encroaching upon their ownership rights and never reinstating them. The struggle to have their authority recognised eventually led to the Te Arawa lakes settlement Act canvassed in chapter three. When asked what the traditional relationship of the Te Arawa people to the lakes was Sir Toby Curtis reply was "our traditional relationship with the lakes was that we owned them." The settlement did not return traditional ownership to the hapu of Te Arawa, instead providing for the lake beds to vest in TALT and the creation of the 'Crown stratum' the TALT website now lists pursuing the ownership of the water as one of its four key goals. ${ }^{437}$ Through the Act TALT has permanent membership of the RTALSG along with BOPRC and RDC. Chapter four showed how the formal co-management agreement has been implemented - exploring all the practical layers and groups within groups that make the programme work. This revealed that through collaborating together, adapting and forming strong working relationships, the organisations have given practical effect to the formal structure provided for in the Act. The Programme is clearly enjoying successes and results through the joint efforts to restore the lakes.

Co-management provides for the engagement of inidgenous peoples in resource management although it does not necessary restore their ownership rights. According to New Zealand law stealing another person's property is illegal. ${ }^{438}$ Generally the appropriate restitution would be to return stolen property, in its entirety to the true owner - to do this in treaty settlements is clearly politically controversial. The Crown has acknowledged the rights of Te Arawa to the lakes and the wrongs suffered, here co-management has been used to provide an alternative to the total transfer of all management rights and responsibilities.

\footnotetext{
437 Te Arawa Lakes Trsut Website Available: http://www.tearawa.iwi.nz/about-trust Accessed: 04/05/2014

${ }^{438}$ Crimes Act 1961, s 219
} 
The acceptance by the true owner of a co-management arrangement should provide them with the degree of power sharing they aspire to, whatever the extant of that maybe. Comanagement should not be used as a substitute to ownership unless both parties genuinely wish to do so. That said, co-management can be an excellent way of returning effective control to iwi. It is thus important to design and operate it well in order to achieve that.

The assessment of the co-management in practice, in chapter four shows that if an indigenous group does choose co-management it is very important to ensure that they are involved throughout all tiers of the co-management arrangement. The formal agreements do not provide (and cannot provide) for every possible evolution that the the management structure will undergo through the adaptive process. Therefore the indigenous group needs to be 'at the table' where the actual power is held, not just on a committee that may in practice have little real power.

It is important for the indigenous group to be aware of being the minority party, and the risks this presents, here the RTALSG is a construct stemming from the legal obligations of the RDC and the BOPRC under the RMA. Meanwhile TALT's responsibility stems from their traditional role as the owners of the lake. The BOPRC and RDC are faces of the state and TALT is the indigenous group, this means that TALT is in the minority on the RTALSG. However in practice this does not necessitate that they will be overwhelmed and out numbered by the state agencies. The RTALSG makes decisions by consensus but the reality is that TALT could have been marginalized in this process and potentially still could if the relationships between parties deteriorated or if future councils decided to form an alliance against TALT. This is of course unlikely but the reality is the settlement legislation does not provide a majority or 50\% share to TALT and therefore the risk exists. The indigenous group should not be in a position to rely on the goodwill of the other comanagement parties. It puts them in an inherently weak position.

In this case TALT's role as identified in the MOU as the 'cultural lens' overseeing the Programme does not mean they are limited in that role. TALT is still involved in the other facets of the lake management; they also approve policy and perform the functions of the 
other RTLSG members insofar as the strategy is concerned. The actual implementation and staff for the Programme's tasks comes from the BOPRC, who has the state funding to contribute to the Programme. As identified in chapter four TALT is not funded in their role on the RTALSG, and this is a deficiency in the arrangement, the trust should not have to fund their own redress.

Below is a list of factors from the literature identified in chapter one, plus factors stemming from lessons on the Te Arawa co-management, for indigenous peoples to consider when entering into a co-management arrangement; it may be optimal to have all of these factors present:

1. Prior relationships;

2. Bi-annual external auditing;

3. Equal footing in negotiations (Coombes);

4. Funding for their involvement in the co-management itself as an essential management partner (not using settlement funds);

5. Adaptive, learning by doing not fixed management;

6. Consensus based decisions;

7. Conflict resolution procedure (Castro);

8. Annual revolving chairperson;

9. Involvement throughout all tiers of the Programme;

10. Equal or greater power than the other parties;

11. Control of infrastructure and agenda setting.

In the co-management of the Te Arawa Lakes the organizations have visibly worked well together. Unified by a need to defeat a common enemy (the degradation of the lakes) has helped three separate organizations combine to achieve environmental results. They have implemented an adaptive system through trial and error and added layers with the PSG and workstreams to improve the Programme over the course of ten years of operation. The comanagement is an example where the formal agreement was not so comprehensive as to be prohibitive of future development. It previewed a basic schema from which the 
organizations could build and develop their own practices and policies. The Programme has evolved and matured throughout its 10 years in operation. TALT involvement in two new initiatives shows progress in the recognition of and provision for Te Arawa's traditional relationships with the lakes. The Programme has moved forward from its focus on just water quality to other areas. There was, understandably, a period where the parties found their roles and responsibilities and the Programme improved itself from the 2012 IQANZ report. The incorporation of Te Arawa traditional practices is a work in progress.

In settling historical grievances the paramount consideration should be what the indigenous group's goal for redress is - if they want full ownership then co-management will not be a suitable option, as a redress tool. Co-management does have an inherent limitation in that it necessitates state involvement, however if co-management or co-governance is desired then real power sharing can be achieved through negotiations and a presence throughout each tier of the management programme. The achievements of this co-management parties is testament to their strong working relationships and the energy of each partner, this sets the lakes up for a future were they are on track to be safe for swimming returning to their former state.

It is very important to evaluate whether the co-management arrangements that are entered into through settlement do provide for effective and genuine power-sharing between the state and the indigenous group. If they do not then this can be a guide to others entering into negotiations. The wai 262 report into flora and fauna outlined how Māori have become increasing frustrated with the lack of meaningful engagement provided to them under the RMA and had sought the ability to exercise their authority and kaitiaki role over natural resources through co-management. The Waitangi Tribunal states: ${ }^{439}$

in general, it is Treaty settlements- not DOC policies or initiatives - that have led the way in sharing or transferring control over conservation taonga.

\footnotetext{
${ }^{439}$ Ko Aotearoa Tēnei: A Report into Claims Concerning New Zealand Law and Policy Affecting Māori Culture and Identity (Wai 262, 2011)
} 
The Tribunal identified a wide spectrum of redress and management outcomes had occurred through various settlements. The Waitangi Tribunal has inquired into the different roles, rights and responsibilities of the two treaty partners. Their treatment of this subject has incorporated analysis of the English language version and the Te Reo version of the Treaty of Waitangi, finding that the Crowns role to govern must be balanced with providing for tino rangatiratanga. At the centre of this debate has been the positions that were created for each treaty partner under the treaty.

The English version providing that the Crown would hold sovereignty over New Zealand whilst the Māori version provided for the Crown to have kawanatanga. The different meanings of the two words have been debated, the Tribunal has held that Sovereignty was ceded The Muriwhenua Fishing Report $1988^{440}$ found the ceding of sovereignty or kawanatanga empowered the Crown to make laws for conservation but this right is to be exercised in light of article 2 and should not diminish the principles of article 2 or the authority of the tribes to exercise control. Therefore the Crowns sovereignty to make laws regarding conservation was subject to the right of Māori to exercise tino rangatiratanga finding that "Tino rangatiratanga therefore refers not to a separate sovereignty but to tribal self management on lines similar to what we understand by local government" ${ }^{441}$ The stage one Te Paparaki report found sovereignty was not ceded to the Crown by treaty signatories rather they agreed to share power - "they and Hobson were to be equal, although of course they had different roles and different spheres of influence." 442 This Tribunal report can have implications for future negotiations occurring between the two treaty partners, especially in the area of co-management and co-governance, in particular the removal of a presumption that the Crown has the sovereignty to make the laws in relation to resources and allowing for real power sharing.

A settlement option to truly recognise traditional ownership and provide full restitution where land and resources have been unlawfully taken is to vest full ownership back to indigenous owners with some provision for the involvement in the management of the

\footnotetext{
440 The Muriwhenua Fishing Report, 1988.

441 The Muriwhenua Fishing Report, 1988 page 187.

${ }^{442}$ Waitangi Tribunal, Stage 1 of the Te Paparahi o Te Raki Inquiry Report (Wai 1040, 2014), at 527.
} 
resource to the state. The benefits of state involvement discussed in chapter one could be utilised for an initial period until full management could vest in the original owners. This represents an inversion of the current status quo whereby the Crown owns resources and provides for limited involvement by the indigenous group.

The future of co-management and co-governance arrangements with indigenous people and the state is promising; the groundbreaking Te Urewera settlement ${ }^{443}$ makes the Te Urewera national park a legal identity in itself, with Tūhoe having increasing control over the management board which is to operate according to Tūhoe customs and values. ${ }^{444}$ This shows the progress that treaty settlements have made, as the Crown and local government becomes more confident and comfortable with greater devolution of management functions to the original owners. As Te Arawa pursue the return of their traditional ownership of freshwater, the lakes may become their own legal person, each an ancient tūpuna. Whilst on the journey of their freshwater claim Te Arawa continues to work with the BOPRC and RDC towards restoring the lakes through the co-management arrangement in place. In the near furture there is potential for greater Te Arawa imput and power sharing as envisioned by the treaty signatories in 1840 .

\footnotetext{
443 Te Urewera Act 2014

444 Ibid; See: Jacinta Ruru, Tūhoe-Crown settlement - Te Urewera Act 2014 (2014) Maori Law Review. Available: http://maorilawreview.co.nz/2014/10/tuhoe-crown-settlement-te-urewera-act-2014/ Accessed : 01/11/2014.
} 


\section{Bibliography}

\section{Table of Cases}

United States v Washington 1974 [Boldt Decision]

\section{New Zealand}

Huakina Development Trust v Waikato Valley Authority [1987] 2 NZLR 188.

Wi Parata v Bishop of Wellington (1877) 3 NZ Jur NS (SC) 72.

Ngai Tahu Māori Trust Board v DG of Conservation [1995] 3 NZLR 553

Tamihana Korokai v The Solicitor General 1912 CA

\section{Australia}

Northern Territory of Australia v Arnhem Land Aboriginal Land Trust, [2008] HCA 29

Commonwealth v Yarmirr [2001] 208 CLR 1.

\section{Legislation New Zealand}

Conservation Act1987

Crimes Act 1961

Local Government Act 2002 
Resource Management Act 1991

Te Arawa Lakes Settlement Act 2006

Thermal-Springs Districts Act 1881

Te Uri o Hau Settlement Act 2002

Te Urewera Act 2014

Waikato-Tainui Raupatu Claims (Waikato River) Settlement Act 2010

\section{Deeds of Settlement}

Te Arawa Deed of Settlement 2004

\section{Legislation Australia}

Aboriginal Land Rights (Northern Territory) Act 1976

\section{Texts}

Armitage, D., Berkes,F., and Doubleday, n. eds., Adaptive Co-Management, Vancouver, (University of British Columbia Press 2007

Banner, Stuart How the Indians Lost Their Land: Law and Power on the Frontier (Harvard University Press, 2005).

Banner, Stuart Possessing the Pacific: Land, Settlers, and Indigenous People from Australia to Alaska (Harvard University Press, 2007). 
Borrini-Feyerabend, G., Farvar, M.T., Nguinguiri, J.C. and Ndangang, V.A. Comanagement of Natural Resources: Organising, Negotiating and Learning-by-Doing. (Kasparek Verlag, Heidelberg, Germany 2000)

Beaglehole, J.C, ed. 1955, The Journals of Captain James Cook on his journey of discovery, Vol 1, The Voyage of the Endeavor 1768 - 1771. 2 vols.2d ed. Sydney, Australia: Halstead Press

Brown, William 1845, New Zealand and its Aborigines. London: Smith, Elder

Bunnell, F.L., Dunsworth, B.G., Kremsater, L., Huggard, D., Beese, W.J., and Sandford, J.S. Forestry and biodiversity - learning how to sustain biodiversity in managed forests. UBC Press (in press), 2007

Ferguson, Niall, (2004). Empire, The rise and demise of the British world order and the lessons for global power. Basic Books. ISBN $\underline{\text { 0-465-02328-2 }}$

Grace, John Te E. Tuwharetoa A. H. \& A. W. Reed, 1960.

Gray, Andrew Indigenous Rights and Development: Self-Determination in an Amazonian Community (Berghahn Books, 2003).

Jentoft, S., Co-management - The Way Forward (2002) in Geheb, K. and. Sarch, M-T (eds.), Africa's Inland Fisheries: the Management Challenge

Kawharu, Merata [ed], Whenua Managing our Resources, Hutia te Rito o te Harakeke, A flaxroot Understanding of Resource Management, Huhana Bubbles Mihinui, 2002, Reed Publishing

King, Michael The Penguin History of New Zealand (Penguin Books NZ Limited, Auckland, 2003) 
Kooiman, Jan, Bolvink, Maarten, The Governance Perspective, in Kooiman, Jan, Bolvink, Maarten, Jentoft, Svein and Pullin, Roger (Eds.) Fish for Life: Interactive Governance for Fisheries( 2005)

Locke, John Two Treatises of Government: A critical edition with an introduction and an apparatus criticus by Peter Laslett (2nd ed, Cambridge University Press, Cambridge, 1967)

Merata Kawharu [ed], Whenua Managing our Resources, Mangatu, Rutene Irwin and John Ruru, Reed Publishing (2002)

Ostrom, Elinor (Ed); Dietz, Thomas (Ed); Dolšak, Nives (Ed); Stern, Paul C. (Ed); Stonich, Susan (Ed); Weber, Elke U. (Ed) The drama of the commons. Division of Behavioral and Social Sciences and Education Washington, DC, US: National Academy Press. (2002)

Ostrom $\underline{E}$, Gardner R, Walker J Rules, games, and common-pool resources, 1994 University of Michigan 1994

Pinkerton, Evelyn (Ed.), (1989), Co-operative Management of Local Fisheries. (University of British Columbia Press, Vancouver)

Pinkerton, Evelyn (2003), "Toward specificity in complexity: understanding comanagement from a social science perspective" In: Wilson, D. C., Nielson, J. R., and Degnbol, P. (Eds.), The Fisheries Co-management Experience. (Kluwer, Dordrecht, 2003)

Sara Singleton Institutions of Governance in Pacific Northwest Salmon Fisheries Commons Problems, Collective Action and Efficiency: Past and Present Journal of Theoretical Politics 1999 11: 367 
Singleton, Sara. Constructing Cooperation: The Evolution of Institutions of Comanagement, (Michigan University Press, Michigan, 1998)

Stafford, Donald Murray Te Arawa: A History of the Arawa People, Reed 1967, Indiana University

Williams, J. A. Politics of the New Zealand Māori: Protest and Co-operation 1891 1909, Auckland University Press/ Oxford University Press, Auckland, 1969.

\section{Journal Articles}

Abell, J.M., Hamilton, D.P. and Paterson, J. (2011), "Reducing the external environmental costs of pastoral farming in New Zealand: experiences from the Te Arawa Lakes, Rotorua" Australasian Journal of Environmental Management, 18:3, 139-154, DOI: $10.1080 / 14486563.2011 .591520$

Altman, J. and Jackson, S., "Indigenous Land Management”, in Lindenmayer, D., Dovers, M Harris Olson, and Morton S (eds), Commitments: Reshaping the Lucky Country's Environment (2008)

Banner, Stuart, "Conquest by Contract: Wealth Transfer and Land Market Structure in Colonial New Zealand," (2000) Law \& Society Review Vol 34, No. 1

Banner, Stuart "Two Properties, One Land: Law and Space in Nineteenth-Century New Zealand" (1999) Law \& Social Inquiry Vol. 24, No. 4807.

Berkes, Fikret and Carlsson, Lars "Co-management Concepts and Methological Implications" (2005) Journal of Environmental Management 75 
Berkes, Fikret "Evolution of Co-management Role of Knowledge Generation, Bridging Organisations and Social Learning"(2008) Journal of Environmental Management 90:1692-1002,

Berkes, Fikret, McCay, J Bonnie and. Acheson, James M "The Tragedy of the Commons: Twenty-Two Years Later" Human Ecology, Vol. 18, No. 1, 1990

Berq, Laura "Let Them Do as They Have Promised" (1995), Hastings West-Northwest Journal of Environmental Law and Policy, Vol. 3, Issue 1

Booth, Annie L., and Skelton, Norm W., "You spoil everything!” Indigenous peoples and the consequences of industrial development in British Columbia Environment, Development and Sustainability A Multidisciplinary Approach to the Theory and Practice of Sustainable Development Volume 13 Number 4 Environ Dev Sustain (2011)

Castro Alfonso Peter, and Nielsen, Erik "Indigenous people and co-management: implications for conflict management". Published in: Environmental Science and Policy Volume 4, No. 4/5, August 2001

Fitzpatrick, Patricia, Sinclair, John A., and Mitchell, Bruce (2008) „Environmental Impact Assessment Under the Mackenzie Valley Resource Management Act: Deliberative Democracy in Canada's North? "Environmental Management 42:1-18, 16.

Guillet, David "Co-management of Natural Resources: The Long View from North Western Spain" (2002) Environment and History 8, No 2.

Hardin, G., (1968). "The Tragedy of the Commons". Science 162 (3859)

Kropotkin, Peter "Mutual Aid: A Factor of Evolution, Chapter 5: Mutual Aid in the Medieval City" (1902), Kropotkin, P. Mutual Aid: A Factor of Evolution, (New York University Press, 1972) 
Morse, Bradford W “Indigenous Peoples and Water Rights: Does the United Nations' Adoption of the Declaration on the Rights of Indigenous Peoples Help?" 20 Water Law 254.

Ostrom, Elinor and Schlager, Edella "Property-Rights Regimes and Natural Resources: A Conceptual Analysis" (1992), Land Economics, Vol. 68, No. 3 (University of Wisconsin Press)

Plummer, Ryan and Armitage, Derek (2007), “A resilience based framework for evaluating adaptive co-management: linking ecology, economics and society in a complex world", Ecological Economics 61

Roberton, J.B.W., "The Role of Tribal Tradition in New Zealand Prehistory”, The Journal of the Polynesian Society, Vol. 66, No. 3 (September 1957)

Robinson C.J., and Wallington, T.J. "Boundary work: engaging knowledge systems in co-management of feral animals on Indigenous lands". (2012) Ecology and Society 17(2): 16. Available: http://dx.doi.org/10.5751/ES-04836-170216

Ruru, Jacinta, "Undefined and Unresolved: exploring Indigenous rights in Aotearoa New Zealand's freshwater legal regime" (2009) 20 WL 236

Ruru, Jacinta, Tūhoe-Crown settlement - Te Urewera Act 2014 (2014) Maori Law Review

Salmon, Guy, Sundström, Matilda and Zilliacus, Kim "Environmental Management and Natural Resource Allocation Frameworks of New Zealand, Sweden and Finland: A Comparative Description Ecologic Foundation" (2005) New Zealand Ecologic Research Report No 1. 
Singleton, Sarah "Cooperation or Capture? The Paradox of Co-management and Community Participation in Natural Resource Management and Environmental Policymaking" (2000) Environmental Politics 9(2)

Tipa, Gail and Welch, Richard (2006) "Co-management of Natural Resources: Issues of Definition from an Indigenous Community Perspective" Journal of Applied Behavioral Science 42

Williams, Jim (1997) "Mauri and the Traditional Māori Environmental Perspective" Environmental Perspectives, No. 14, March/April.

Williams, Jim. (2006). "Resource Management and Māori attitudes to water in Southern New Zealand" in New Zealand Geographer, (62)

\section{Thesis and Dissertations}

Hall, Tredegar Rangiātea, Delamere "Restoring the flow: Challenging the existing management frameworks to integrate Mātauranga Māori”, A thesis submitted in fulfilment of the requirements for the degree of Master of Social Sciences.

Morrison, Virginia, Environmental Justice and co-management of the Te Arawa Lakes, Environmental Management), University of Auckland, 2011

Thompson, Tanya June The Rotorua Lakes: A Legal History, 1 September 1995 , Victoria University

Tipa, Gail (2003) "Indigenous communities and the co-management of natural resources: the case of New Zealand freshwater management" (Thesis, Doctor of Philosophy). University of Otago. 


\section{Waitangi Tribunal Reports}

Waitangi Tribunal, The Mohaka River Report (Wai 119 Waitangi Tribunal 1992)

Waitangi Tribunal, The Whanganui River Report (Wai167 Waitangi Tribunal 1999)

Waitangi Tribunal, The Interim Report on the National Freshwater and Geothermal Resources Claim (Wai 2358, 2012)

Waitangi Tribunal, Te Ika Whenua Rivers Report (Wai 22, 1998)

Waitangi Tribunal, Whanganui River Report (Wai 167, 1999)

Waitangi Tribunal Te Ika Whenua River Report, Waitangi Tribunal (Wai 22, 1998)

Waitangi Tribunal, Stage 1 of the Te Paparahi o Te Raki Inquiry Report (Wai 1040, 2014)

Ko Aotearoa Tēnei: A Report into Claims Concerning New Zealand Law and Policy Affecting Māori Culture and Identity (Wai 262, 2011)

\section{Treaties}

Treaty of Waitangi 1840

\section{International Instruments}

International Covenant on Economic, Social and Cultural Rights (ICESR) 
International Covenant on Civil and Political Rights (ICCPR)

Rio Declaration on Environment and Development A/CONF.151/26 (Vol. I) 14 June 1992, Rio de Janeiro, Brazil

United Nations Declaration on the Rights of Indigenous Peoples (adopted by the United Nations General Assembly 13 September 2007)

C169 - Indigenous and Tribal Peoples Convention, 1989 (No. 169) Convention concerning Indigenous and Tribal Peoples in Independent Countries (Entry into force: 05 Sep 1991)Adoption: Geneva, 76th ILC session (27 Jun 1989)

Johannesburg Declaration on Sustainable Development A/CONF.199/20 at 25.

\section{Discussion Papers}

Assembly of First Nations, Co-Management Discussion Paper.

Available: http://www.afn.ca/uploads/files/env/comanagement_paper.pdf

Godden, Lee “Indigenous Peoples’ Rights to Water: Environmental Flows, Cultural Values and Tradeable Property Rights in Australia” Provisional Discussion Paper Indigenous Peoples' Legal Water Forum, University of Otago Stadium Centre Wellington New Zealand $27^{\text {th }}$ July 2009.

Collins, L M "Implementing the Human Right to Water in Canada: A Discussion Paper" (Prepared for the United Nations Association in Canada March 2007).

Morgan, M, Strelein, L and Weir, J, Indigenous Rights to Water in the Murray-Darling Basin: In support of the Indigenous final report to the Living Murray Initiative, Research 
Discussion Paper Number 14, Australian Institute for Aboriginal and Torres Strait Islander Studies (2004), p 9. At: http://www.aiatsis.gov.au/

Berkes, Fikret, George, Peter, and Richard Preston Co-Management: the evolution of the theory and practice of Joint administration of living resources. TASO Research Report, Second Series, No. 1 Paper Presented at the Second Annual Meeting of IASCP University of Manitoba, Winnipeg, Canada, Sept. 26-29, 1991

\section{Policy Papers}

Commission on Human Rights, Prevention of Discrimination and Protection of Indigenous Peoples and Minorities, Indigenous peoples and their relationship to land, Final working paper prepared by the Special Rapporteur, Mrs Erica-Irene A. Daes, SubCommission on the Promotion and Protection of Human Rights, Fifty-third session, E/CN.4/Sub.2/2001/21, 11 June 2001, para 90.

Dairy Industry Position Paper on Lake Rotorua 2009, Dairy NZ, Federated Farmers, Fonterra and Farmers in the Rotorua Catchment

Durette M, Indigenous Legal Rights to Freshwater: Australia in the International Context, Centre for Aboriginal Economic Policy Research Working Paper No. 42/2008 (2008), p vii. At: http://www.anu.edu.au/caepr/Publications/WP/CAEPRWP42.pdf, (viewed 28 August 2008).

Haysom, Nicholas, and Kane, Sean Briefing Paper Centre for Humanitarian Dialogue Negotiating Natural Resources for Peace: Ownership, control and wealth-sharing, (Henry Dunant Centre for Humanitarian Dialogue, 2009), at 5. Available: http://comparativeconstitutionsproject.org/files/resources_peace.pdf Accessed : 22/02/2015 
Nursey-Braya, Melissa and Rist, Phillip Co-management and protected area management: Achieving effective management of a contested site, lessons from the Great Barrier Reef World Heritage Area (GBRWHA) National Centre for Marine Conservation and Resource Sustainability, Locked bag 1370, AMC UTAS, Tasmania, Launceston, Australia, at 1.

Williams, Dr J Morgan, Parliamentary Commissioner for the Environment, Parliamentary Commissioner for the Environment, 2006. Restoring the Rotorua Lakes: The ultimate endurance challenge. Wellington: Parliamentary Commissioner for the Environment at 9.

Salmon, Guy, Sundström, Matilda and Zilliacus, Kim (2005) "Environmental Management and Natural Resource Allocation Frameworks of New Zealand, Sweden and Finland: A Comparative Description Ecologic Foundation”, New Zealand Ecologic Research Report No 1, at 12.

Available: http://www.fish.govt.nz/NR/rdonlyres/4CB96899-6B0A-4890-810A183A338AC847/3340/ComparisonResourceManagementFrameworksNZSwedenFinl.pdf

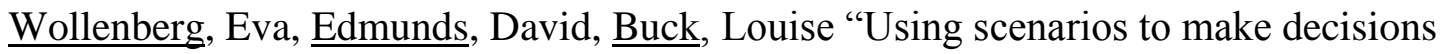
about the future: anticipatory learning for the adaptive co-management of community forests” Center for International Forestry Research, P.O. Box 6596 JKPWB, Jakarta, Indonesia 1006

\section{Reports and Reviews}

Brad Coombes, Contested conservation legacies and the co-option of Māori resistance through co-management, Senior Lecturer, School of Geography and Environmental Science, University of Auckland. 
Paul Dell, "The Rotorua Lakes Protection And Restoration Programme, Outline of Project Structure and Timeline Prepared" (Environment Bay of Plenty Environmental Publication, Whakatane, 2004)

Local Government New Zealand (2007), Co-management: case studies involving local authorities and Māori Available:http://policyprojects.ac.nz/phillipanorman/files/2011/10/CoManagementCaseSt udiesInvolvingLocalAuthoritiesAndMaoriJanuary2007.pdf

G.R. Fish, Limnoligical Conditions and Growth of Trout in three lakes near Rotorua, Marine Department, Rotorua, at 2.

D. I. Forsyth and R. H. S. McColl Limnology of Lake Ngahewa North Island, New Zealand, Ecology Division, Department of Scientific and Industrial Research, P.O. Box 415, Taupo, New Zealand (Received 16 January 1975)

Suzanne Hoverman, Karen Delfau, Poh-Ling Tan, Developing alternative management models for Indigenous water plans and strategies in Australia's north. Final report Track NAWFA Social and Cultural Values Project: Sub-project 3 April 2012 Available: http://www.environment.gov.au/system/files/resources/03609759-af40-409db98d-da3193c588d7/files/nawfa-developing-alternative-management-models.pdf

Vaughan Payne, facilitator, Rotorua Lakes Strategy co-management project team. "Rotorua Lakes strategy co-management options: report" 2001

Helen Ross, Cathy J. Robinson and Marc Hockings, Evaluation of Indigenous comanagement of natural Resources, School of Natural and Rural Systems Management, University of Queensland, Gatton. CSIRO Sustainable Ecosystems, Brisbane

Te Arawa Lakes Programme annual report 2012/2013 
Te Arawa Māori Trust Board 1924 - 1974, A review of its first 50 years, at 8.

State of the Rotorua/Te Arawa Lakes 2009-2010. An update on the current state of the Rotorua/Te Arawa Lakes and what actions are being taken to protect and restore them

T.K.K.B. Morgan, Te Arawa, Ngati Pikiao, Ngati Kahungunu, Kai Tahu An indigenous perspective on water recycling school of Civil and Environmental Engineering, The University of Auckland, New Zealand 2005

D. P. Hamilton, M. J. Landman Preface: Lake restoration: an experimental ecosystem approach for eutrophication control Received: 10 November 2010, University of Waikato

David P. Hamilton, A Historical and Contemporary Review of Water Quality in the Rotorua Lakes, Department of Biological Sciences, University of Waikato

Parliamentary Commissioner for the Environment. 2006. Restoring the Rotorua Lakes: The ultimate endurance challenge. Wellington: Parliamentary Commissioner for the Environment

The James Bay and Northern Quebec Agreement and the Northeastern Quebec Agreement - 2005 - 2006 and 2006-2007, Annual Report Author: Published under the authority of the Minister of Indian Affairs and Northern Development and Federal Interlocutor for Métis and Non-Status Indians. 2009

Restoring Kōaro in the Rotorua Lakes Science Centres: Freshwater and Estuaries, $\underline{\text { Te }}$ Kūwaha NIWA contacts: Dave Rowe. External people involved: Roku Mihinui (Te Arawa Lakes Trust) era Smith (Te Arawa Lakes Trust),Matt Bloxham (BOPRC) Available: http://www.niwa.co.nz/freshwater-and-estuaries/projects/restoringk\%C5\%8Daro-in-the-rotorua-lakes 


\section{Internet Sources}

Tapsell, Paul "Te Arawa - Settlement and migration", Te Ara - the Encyclopedia of New Zealand, available: http://www.TeAra.govt.nz/en/te-arawa/page-2

"Natural Resources" Oxford Dictionaries

Available:http://oxforddictionaries.com/definition/english/natural-resources

Te Arawa Iwi website

Available: http://www.tearawa.iwi.nz/about-trust

About the Te Arawa Trust

Available: http://www.tearawa.iwi.nz/about-trust

Bay of Plenty Regional Council, Local Governance Statement, August 2011

Available:

http://www.boprc.govt.nz/media/102209/localgovernancestatementaug2011.pdf

Bay of Plenty Regional Council, Organisational Structure

Available: http://www.boprc.govt.nz/council/organisational-structure/

Human Rights and the Treaty of Waitangi, Crown and Tangata Whenua Available:http://www.hrc.co.nz/human-rights-and-the-treaty-of-waitangi/crown-tangatawhenua-engagement/te-arawa-rotorua-lakes-restoration-programme

Programme Finance Plan

Available: http://www.boprc.govt.nz/media/295934/rotorua-te-arawa-lakes-strategygroup-meeting-agenda-friday-30august-2013-part-1.pdf

Accessed: 22/02/2015 
Programme Finance Plan

Available:

http://www.boprc.govt.nz/media/322168/20140319_rotoruatearawalakesstrategygroup19march2014_rev.pdf

Memorandum of Understanding 2007

Available: http://www.boprc.govt.nz/media/276243/lakes-070400-

rotorualakesstrategymemorandumofunderstanding.pdf

Rangiheuea, Anaru Ririwai The Te Arawa Tribe's Relationship with its lakes, Available: http://docs.niwa.co.nz/library/public/0473111322.pdf\#page=94

Rotorua Lakes Website

Available: http://www.rotorualakes.co.nz/lakes

Taonui, Rāwiri "Ngā waewae tapu - Māori exploration - Te Arawa explorers”, Te Ara the Encyclopedia of New Zealand, available: http://www.TeAra.govt.nz/en/nga-waewae-tapu-Māori-exploration/page-5

Paul Tapsell, 'Te Arawa - 'European Impact', Te Ara - the Encyclopedia of New Zealand, updated 22-Sep-12 URL: http://www.TeAra.govt.nz/en/te-arawa/page-4

Report to: Rotorua Te Arawa Lakes Strategy Group Meeting, Date: 08 June 2012, Report from: Warwick Murray, Group Manager Land Management Update on Health Check Report for the Rotorua Lakes Programme, File Reference: 1.00250 Available:

http://www.boprc.govt.nz/media/216085/rotorua_te_arawa_lakes_strategy_group_meetin g_agenda_- 8 june_2012.pdf at 18 and 19. 
Tapsell, Paul 'Te Arawa - Economic and social change', Te Ara - the Encyclopedia of New Zealand, updated 22-Sep-12

Available: http://www.TeAra.govt.nz/en/te-arawa/page-6

Vision and Strategy for the Lakes of the Rotorua district.

Available http://www.rotorualakes.co.nz/vdb/document/533

Walrond, Carl 'Acclimatisation - Early acclimatisation societies', Te Ara - the

Encyclopedia of New Zealand, updated 13-Jul-12

Available: http://www.TeAra.govt.nz/en/acclimatisation/page-2

World Trade Report 2010

Available: http://www.wto.org/english/res_e/booksp_e/anrep_e/wtr10-2b_e.pdf

\section{Interviews}

Interview with Sir Toby Curtis, Chairman of the Te Arawa Lakes Trust (Author, 22 June 2014)

Interview with the Honourable Steve Chadwick, Mayor of Rotorua (Author, 9 September 2014) 